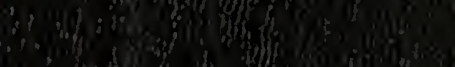

s.

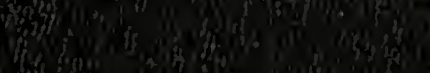

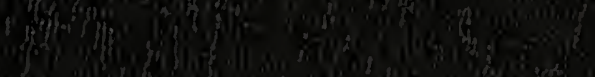

2... 
J. J. FLYNN 
Arehic Fr. Flym 





\section{State of Sonnecticut \\ PUBLIC DOCUMEN'T No. 47}

\section{State Geological and Natural History Survey}

\section{COMMISSIONERS}

ROLLIN S. WOODRUFF, Governor of Connecticut (Chairman) ARTHUR Twining HAdLey, President of Yale University BRADFord PAUL RAYMOND, President of Wesleyan University FLAVEL SWeEten Luther, President of Trinity College (Secretary)

Rufus Whittaker Stimson, President of Connecticut Agricultural College SUPERINTENDENT

William NORTH RICE

\section{Bulletin No. 10}

\section{HARTFORD}

Printed for the State Geological and Natural History Survey 1908 



\title{
A PRELIMINARY REPORT
}

ON

\section{THE ALGÆ OF THE FRESH WATERS OF CONNECTICUT.}

\author{
By \\ HERBERT WILLIAM CONN, Ph.D., \\ Professor of Biology in Wesleyan University \\ AND \\ LUCIA WASHBURN (HAZEN) WEBSTER, M.S.
}

HARTFORD

Printed for the State Geological and Natural History Survey 1908 



\section{A Preliminary Report on the Algæ of the Fresh Waters of Connecticut.}

\section{INTRODUCTION.}

The present report is designed to accompany the previous report upon the Fresh-water Protozoa, Bulletin No. 2 of this Survey. Like that report, it is not claimed to be complete, nor by any means to contain all of our Algæ. But, the work having covered considerable parts of four years, it is thought that it will be found to contain most of the common Algæ in this state, and will therefore be useful as a guide to students of the microscopy of our waters. To wait until all omissions could be filled would clearly postpone unduly the publication of any report. For these reasons this preliminary report is issued at the present time.

Work upon the Algæ is scattered somewhat widely in books and in journals. We have found most valuable, The British Fresh-water Alga, by West. Wolle's Fresh-water Alga of the United States, and his similar work on the Desmids, have also been found extremely useful. The magnificent work of Engler and Prantl has been found of great value, as has also Die Mikroskopische Pflanzenwelt des Süsswassers by Kirchner, and the Analytical Keys of Genera and Species of the.Fresha'ater Alga by Stokes. The most useful publication upon a single group has been that of Hazen - The Ulotrichacere and Chatophoracec, in the Memoirs of the Torrey Botanical Club, XXII, I902.

The key that we have adopted in this Bulletin is based upon that given by West. We have used this because in our experience it has been found to be the most practical and useful. We have, however, modified it in several respects to make it correspond to the key used in the Bulletin on the Protozoa. As so modified, we think it will be found very easy of use for microscopists who are beginning the study of the Algæ. 
We have adopted the plan used in the Bulletin on the Protozoa of indicating by a * in the analytical keys the genera that have been found in our waters. In a number of cases the genera thus indicated have not yet been found by ourselves, although known to occur in Connecticut. We have given descriptions of all the genera likely to be found in this vicinity, whether already known to occur in Connecticut or not.

So far as possible we have determined the species of the forms studied and figured. While there is considerable variation among the individuals of the same species of Algx, it is less than among the Protozoa, and it is less difficult to determine species. In most cases there has been little difficulty in affixing specific as well as generic names to the Algæ found. In some genera the determination of species is nearly impossible without the whole life history of the specimen under consideration. In the genus Spirogyra, for instance, the species are determined with certainty only when one has the zygospores for study. The ordinary student of Algæ is seldom so fortunate as to have the zygospores, and must in these cases make his determination from other characters. We have, therefore, in these cases determined the species as well as possible from the general structure of the plant, thinking this to be more practical than to rely upon the more rarely seen zygospores.

The figures have all been drawn from nature, and all from specimens found by ourselves in our waters. A majority of them have come from the immediate vicinity of Middletown. Collections have been made from other parts of the state, but these other localities have not yet yielded many forms not represented in this immediate vicinity. The Algæ have not been to a very large extent obtained from city reservoirs, since these localities are not very profuse in this kind of life. Roadside pools, ditches by railroads, swamps, stagnant pools, etc., have been more prolific sources of Algre.

The late Isaac Holden made during his life large collections of Algx in the state. The largest number of the types that he collected were marine, but he also made quite extensive collections of the fresh-water forms. A list of the species identified by him in this state has been recently published by 
F. S. Collins (Phycological Notes of Isaac Holden, in Rhodora, vol. 7, p. 222, I905). Since he identified quite a number of species that we have not found, we have, for the purpose of making this report as complete as possible, included in this list all the species reported by him which we have not ourselves identified. These have been appended to our own list, and are distinguished by being inclosed in square brackets [ ]. We have not given any figures of his species, however, all of the species figured having been personally found by ourselves. In a few cases we have noted the collection of certain species in this state by Hazen and by Setchell. No other extensive collections of Algæ are known to us as having been made in the state.

The figures of plates I to XXXI were drawn by Mrs. Webster, except figures $5,8,8 a, 10,28,3 \mathrm{I}, 45,47,49,54,54 a$, $55,57,59,65,72,72 a, 73,77,77 a$, 102, 125, and 147. These together with the 'figures of Plates XXXII to XLIV were drawn by Prof. Conn. Acknowledgment is also made to H. J. Conn from whose work and sketches many of the figures of Plates XXXII to XLIV have been drawn. 


\section{THE ALGÆ.}

The ALG.E are flowerless chlorophyll-bearing water plants. Although sometimes called seaweeds, they are not confined to salt water, but are found in every body of fresh water, on damp stones and soil, and on the trunks of trees. 'They are, however, all true water plants, for the few that live out of water can flourish only in the presence of abundant moisture.

The Algæ show the widest variety in form, size, and structure. They may be unicellular or multicellular; they may be solitary, or gathered into larger or smaller families; they may grow in all directions to form a spherical thallus, or into plates only one cell thick, or into branched or unbranched filaments. When multicellular, all the cells may be alike, or there may be a differentiation of cells, apical and root cells, vegetative and sexual cells being found. The filamentous thallus may present the appearance of a highly developed plant, as in the Rhodophyceæ or Characeæ, or may be a single simple thread, as in the $Z_{y}$ gnemacex.

The coloring matter of the Algæ, either diffused throughout the cell wall, or aggregated in special bodies called chlorop?asts, is predominantly green; but there is hardly any color known which cannot be found in these plants, the colors running from orange and red to purple and black. Their size differs as greatly as their color; some are so small as to test the best microscopes, while others stretch, two hundred feet from their marine beds.

The Algx multiply both by the sexual and the asexual method. The asexual method is universal, the sexual is more uncommon. They reproduce asexually in three ways:- I, By simple division of the mother-cell. In the multicellular forms a small fragment or a branch may separate from the mother plant to form a new one. 2, By means of spores, which are formed from the contents of the vegetative cells, and which have each a cell wall, and may or may not be motile. 3, 
By swarm spores, which lack cell walls and are always motile, usually provided with cilia. The sexual reproduction is of two kinds:- I, Conjugation, or the union of two similar or nearly similar cells called isogamous gametes. These may be either motile cells, as in Ulothrix, or cells of the thallus, as in the Conjugatæ. They join themselves together, and their contents fuse to form a new cell, a zygote, which, after a short period of rest, develops into a new plant. 2, Sex union proper, or the union of two entirely different cells, one of which, the male or sperm, is many times smaller than the other, the female or egg - heterogamous gametes. This occurs, for example, in Chara.

The Algæ are found from the Arctic zone to the Equator, and no genus is confined to a single latitude. We should sadly miss these plants if they were all destroyed. They do much to purify the atmosphere, are used to a considerable extent in medicine, provide food for fishes and for men, fodder for cattle, and fertilization for the ground.

The Algæ are divided into classes as follows:-

CLASS I. CYANOPHYCE在 (Schizophyceæ, Myxophyceæ, or Blue-green Algæ). Containing a blue coloring matter (phycocyanin). Mostly in fresh water, and simple in structure.

CLASS II. BACILLARIE $\approx$ (Diatomaceæ). Containing a brown coloring matter (diatomin). Universal both in fresh and salt water.

CLASS III. HETEROKONT E (Yellow-green Algæ). Containing a large amount of a yellow pigment (xanthophyll). The stored product of assimilation is a fatty substance. Found in fresh water.

CLASS IV. CHLOROPHYCEÆ (Green Algæ). Containing only the green coloring matter known as chlorophyll. The product of assimilation is starch. Very largely freshwater plants.

CLASS V. CHARACE无. Having a stem with nodes and internodes. Sexual reproduction.

CLASS VI. PHÆOPHYCE在 (Brown Algæ). Containing a brown coloring matter, known as phycophæin. Mostly marine. 
CLASS VII. RHODOPHYCE王 (Red Algæ). Containing a reddish coloring matter known as phycoerythrin. Mostly marine.

In the study of the fresh-water Algx we are concerned chiefly with the first five of these classes, the other two being practically confined to salt water, although a few of them, as noted at the end of this report, are inhabitants of fresh water.

\section{CLASS I. CYANOPHYCEÆ.}

(Myxophyceæ, Schizophyceæ, or Blue-green Algæ).

The class Cyanophyceæ is unquestionably the lowest class of the Algæ, many of the species resembling the Bacteria. Their most conspicuous characteristic is the manner in which the greater number of the genera grow in gelatinous masses or strata. They are largely filamentous, though some are unicellular. Some of them grow wherever there is moisture, as on wet rocks, stones, and trunks of trees. Some of the filamentous genera form thick, felt-like coverings upon moist earth and stones. Many of the Cyanophyceæ are provided with heterocysts, which are cells of lighter color and often of greater size than the other cells of the filament. The heterocysts are almost always solitary on the filaments, and their use is not known.

The unicellular and simple colonial genera multiply principally by repeated cell-division, which may occur in every direction or in certain directions only. Asexual reproduction of the large forms takes place in a variety of ways. In some families certain vegetative cells enlarge and form spores; in others the contents of the cells divide into a number of small spores. The Hormogonex reproduce by hormogones. These are short filaments arising from the mother plant, which break away and form new plants. Sexual reproduction is unknown.

Some of the Cyanophyceæ unite with Fungi to form Lichens, in which case they lose much of their distinctive character.

A few of the Cyanophycex, of the family Oscillatoriaceæ, are distinguished for their power of spontaneous movement, which is generally slow, oscillating or gliding. Many of this 
family have a disagreeable odor, giving rise to unpleasant odors and tastes in drinking-water.

There are two orders, as follows :-

ORDER I. COCCOGONEE. Plants unicellular or colonial, not truly filamentous; commonly embedded in a gelatinous matrix, more rarely free-floating.

ORDER II. HORMOGONEÆ. Plants filamentous; filaments single or branched, generally consisting of one or more rows of cells within a sheath, attached to a substratum, or freefloating.

\section{ORDER I. COCCOGONEE.}

The Coccogonex, the lowest form of the Algx, are unicellular or colonial. The colonies vary much in size and shape, and the cells, which are of various forms, are disposed in a variety of ways in the usually hyaline and structureless envelope. Multiplication is usually by simple cell division. Rounded asexual spores have been found in some species, formed inside the wall of the mother-cell.

\section{FAMILY I. CHROOCOCCACEA.}

This family is composed of unicellular forms of Algæ which divide and form daughter-cells; often many generations are involved in one mucilaginous envelope. The envelope varies from firm and lamellose to hyaline and diffluent. The cells often contain red, orange, or violet pigments. The members of this family have been thought to be stages of filamentous Algæ, and Wolle so regarded them ; but more recent algologists give them a distinct place of their own.

\section{Key to Genera.}

1. Cell division in only one direction $\ldots \ldots \ldots \ldots \ldots .2$

Cell division in two directions at right angles, forming plate-shaped or irregular masses .. Merismopedia*

Cell division alternate in the three directions of space 4

2. Cells with thin membrane, without a gelatinous or mucous envelope, single or hanging together in thick rows ................. Synechococcus 
Cells with thick, swollen membranes, which merge into one another and lie in a gelatinous or mucous bed

3. The thick membrane remains present through several generations, so that the cells are enclosed in several membranes; cells elongated .............Gloothece

Cell membranes fused into a structureless jelly in which the cells are arranged without order; cells slightly longer than broad............. Aphanothece

4. Cells at the periphery of spherical colonies ..... 5

Cells densely aggregated in spherical, elongated, or clathrate colonies ..............Microcystis*

Colonies without definite form............ 6

5. Cells spherical, closely and regularly arranged around a hollow sphere .............. Colospharium* Cells peripheric, sparsely scattered......Gomphospharia

6. Cells enclosed in a thick membrane.........Gloocapsa* Cells not enclosed .................. 7

7. Cells with thick, gelatinous, fusing membranes....

Aphanocapsa*

Cells single or in small groups, with membranes which do not fuse................Chroöcoccus*

\section{Description of Genera.}

Merismopedia Meyen.-Cells spherical, or, at time of division, oblong. Their regular method of division produces groups of $4,8,16,32,64$, or 128 cells, associated in a single stratum, making a flat, freely floating, square thallus.

M. glauca (Ehrb.) Näg., Fig. 3 .

M. convoluta Breb., Fig. 4 .

Synechococcus Näg.- Cells cylindrical or oblong, found singly or in series of two or more; cell wall thin.

Glœothece Näg.-Cells oblong or cylindrical, with rounded ends. The cells divide into two nearly spherical daughter-cells. The colorless gelatinous tegument may contain one or often more cells, and this tegument may, in turn, be included in a larger tegument with a family. 
Aphanothece Näg.-Very like Gloothece, with cells longer than broad; but the teguments are confluent, forming a firm gelatinous body which encloses the cells.

Microcystis Kütz. (Polycystis Kütz.; Clathrocystis Henfrey).- Numerous small cells gathered into globular, oblong or irregular families, each with a thin tegument, usually single but sometimes associated with other families, and all enclosed in a common tegument. The cells divide alternately in three directions.

M. cruginosa (Kütz.) (?), Figs. 9, 9a. Sometimes very abundant in reservoirs and giving an unpleasant taste to the water. Frequently thus associated with Anabcna.

Cœlosphærium Näg.- Thallus hollow, spherical, with numerous small spherical cells in families, or scattered at the periphery, embedded in a gelatinous stratum. Multiplication takes place by means of enlarged cells which escape and form daughter-cells, or by constriction and division of the mothercells.

\section{Kuetzingianum Näg., Fig. 7 .}

Gomphosphæria Kütz.-A globose, free, floating thallus, composed of wedge-shaped cells, in pairs, associated in radiating families at the periphery of a solid gelatinous sphere, and furnished with a tegument. The cells divide alternately in three directions.

Glœocapsa Kütz.-- Cells blue-green, steel-blue, reddislı, yellowish, etc., spherical or oblong, with a wide, bladder-shaped integument. The cells divide into two daughter-cells, each furnished with a tegument and both surrounded by the tegument of the mother-cell. The cell membrane is very thick, often lamellated, and the strata frequently separate; either colorless or colored.

G. arenaria (Rab.) (?), Figs. 8, 8a. The specific distinctions in this genus are very uncertain.

[G. violacea (Chorda) Rab.]

Aphanocapsa Näg.-Cells spherical, with a thick, soft tegument; cell division as in Gloocapsa, but individual coats not evident around the cell. 
A. Grevillei (Hass.) Rab., Fig. Io. Masses of this jellylike plant frequently reach $2 \mathrm{~mm}$. in diameter.

Chroococcus Näg.- Blue-green cells, spherical, or angular from mutual pressure, gathered into small families without a distinct tegument. The cells, which are less numerous and more simple than in Glocapsa, divide alternately in three directions.

C. coharens (Breb.) Näg., Fig. 210.

FAMILY II. CHAM ESIPHONIACEA.

Not represented in the United States.

ORDER II. HORMOGONEF.

This order contains all the filamentous Myxophycex. The filaments usually consist of a single row of naked or sheathed cells, but in some genera there are two or more rows in a single sheath. Heterocysts are abundant in some of the genera. The filaments are often branched or provided with a false branch system due to the growth of a number of filaments in close apposition at the base. Asexual reproduction is by hormogones or, more rarely, by spores. The filaments or trichomes are usually cylindrical with blunt or narrowed extremities, but some genera show a gradual attenuation, either from the base to the apex, or from the centre toward each end.

This order includes two sub-orders.

SUB-ORDER I. TRICHOPHOREÆ. Trichomes conspicuously attenuated towards one or both extremities, which are generally hairy.

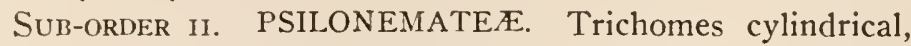
though sometimes narrowed at the extremities.

\section{SUB-ORDER I. TRICHOPHOREÆ.}

A small group with the filaments always attenuated, either toward one end or from the middle to both extremities, and always sheathed. Some genera are provided with heterocysts. There is an asexual reproduction by means of hormogones, but in Glocotrichia the basal cells next the heterocysts develop spores. The threads frequentiy show hair-like projections from their sides. 
FAMILY I. RIVULARIACE.E.

Abundant in mountainous regions, found principally on dripping rocks, in streams and waterfalls, or on the shores of rocky lakes. Our collections not having included such localities, this family is not represented in our figures. The filaments are all attenuated from a long base to a hair-like end. One or two heterocysts are usually located at the base. The sheath is yellow or yellowish-brown, gelatinous, tubular, and often thoroughly lamellated. Asexual reproduction by hormogones, and in Glootrichia and Calothrix asexual spores arise near the basal heterocysts.

\section{Key to Genera.}

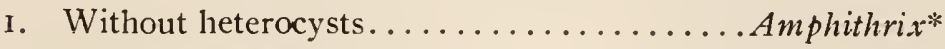

With heterocysts ....................... 2

2. Filaments without gelatinous integument, simple, growing in branched or unbranched tufts, or sometimes singly ............................

Filaments without gelatinous integument, branched, several branches in a common sheath.....Dichothrix*

Filaments with a gelatinous integument, forming a

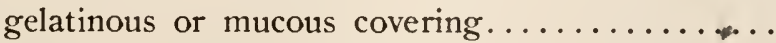

3. Filaments radially disposed; thallus spherical or hemispherical in shape................ 4

Filaments not radiating; thallus plain, cushionshaped $\ldots \ldots \ldots \ldots \ldots \ldots \ldots \ldots$. Isactis

4. Spores present; single-celled or with heterocysts; colonies free, floating............... Glootrichia* Spores lacking; colonies attached.........Rivularia*

\section{Description of Genera.}

Amphithrix Kütz. - The filaments form a thin expanded stratum of a purple or violet color, which consists of two layers. The inferior layer is composed of densely intricate filaments, or of minute radiately disposed series of cells; the superior layer of simple erect filaments closely packed and attenuated.

[A. janthina (Mont.) Born. and Flah.] 
Calothrix Ag. (Mastigonema Schwabe; Mastigothrix Kütz., in part).- Filaments growing in tufts or soft masses, rather rigid, straight and spuriously branched. The branches are younger filaments glued at their bases and part of their length to the parent stem; the apex is delicately hair-like. Heterocysts are normally present and are usually at the base of the branches.

[C. Braunii Born. and Flah.; C. fusca (Kütz.) Born. and Flah.; C. parietina (Näg.) Thur.].

Dichothrix Zanard. Filaments more or less dichotomously branched; several trichomes with their sheaths enclosed within an outer common sheath. Heterocysts basal, or intercalary, or absent in one species.

[D. gypsophila (Kütz.) Born. and Flah.; D. Hosfordii (Wolle) Born. and Flah.; D. Orisiniana (Kütz.) Born. and Flah.]

Isactis Thur. The filaments are erect and parallel, attached at the base. They are glued together by a more or less firm mucilage, and are often encrusted with lime, forming flat strata.

Glœotrichia J. Ag. The filaments, with spores in the lower part, are radiate, sometimes spuriously branched, each enclosed in a distinct, broad sheath, which is often furrowed at the base and transversely folded. All the filaments are enclosed in a more or less spherical jelly.

G. Pisum (Ag.) Thur., Fig. 214.

Rivularia (Roth.) Ag. (Zonotrichia J. Ag.; Limnactis Kütz.; Schizosiphon Kütz., in part).

Filaments radiating, with basal heterocysts, but no spores. A more or less firm mucilage binds the filaments into a hemispherical or bladder-like, well-defined thallus. One species of Rivularia has been found in our studies, but no figure of it is given in this report.

FAMILY II. CAMPTOTRICHACEE.

Not found in the United States. 
SUB-ORDER II. PSILONEMATEE.

This sub-order contains the greater part of the Hormogonex. The filaments, with or without a sheath, are cylindrical, sometimes showing globular swellings. The sheath may be very thin, hyaline and gelatinous, or tough and lamellose. The apical cell, or sometimes that and the sub-apical cell, are occasionally attenuated, or the filaments may end obtusely.

\section{Key to Families.}

I. Filaments showing true branching....... STIGOnEMACE Filaments showing false branching; heterocysts

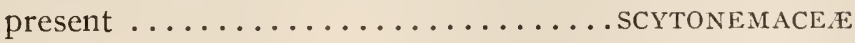
Filaments usually simple, without branching; where they show false branching they are without heterocysts ............................ 2

2. Filaments nearly straight; heterocysts absent.....

OSCILLATORIACE.E

Filaments tortuous; heterocysts present.........

NOSTOCACE.

FAMILY I. OSCILLATORIACE $Æ$.

The distinguishing feature of this family, which is the largest one of the Psilonemater, is the absence of heterocysts. The trichomes are a single and regular row of cells, although occasionally false branching is seen. Sometimes the cells are so closely joined that the whole seems a perfectly homogeneous cylinder; but at other times there are constrictions at the ends of the cells. Apical cell sometimes attenuated. The filaments are nearly always in sheaths of various character, which sometimes enclose more than one filament. Some of the genera show gliding or rotary motion. They occur in great profusion, submerged in ponds and ditches, or form scums upon their surface.

There are two sub-families, as follows: -

Sub-family I. Lyngbyeæ. Only one trichome in a sheath.

Sub-Family II. VAginariez. Several trichomes in one sheath which is often branched. 


\section{SUB-FAMILY I. LYNGBYEÆ.}

In this sub-family there is never more than one trichome in a sheath, and the sheath may be thick or thin, or even wanting. In some genera the trichomes are twisted. The cells may be of varying thickness and length, but usually the thicker the trichome the shorter the cell. Oscillatoria, Phormidium, and Spirulina exhibit a rotary or gliding motion.

\section{Key to Genera.}

I. Trichomes consisting of many cells.......... 2 Trichomes consisting of one cell, spirally twisted....

Spirulina*

2. Filaments simple, or falsely branched; sheaths firm; apices of filament straight...............

Filaments simple; sheaths thin, always hyaline, mucous, and more or less readily fusing together; apices of trichomes straight; oscillating or rotary

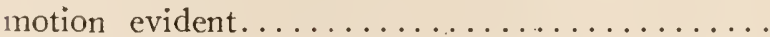

3. Filaments free, or forming felt-like masses; pseudobranches present, often in pairs........Plectonema* Filaments forming erect tufts; pseudo-branches often

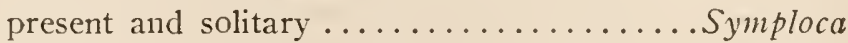

Filaments free and unbranched; free-floating, or forming a matted stratum............Lyng $b_{y} a^{*}$

4. Filaments more or less agglutinated by their mucous sheaths; cells of filaments often slightly separated by a thin mucous layer.............Phormidium* Filaments destitute of sheaths; free, straight or with curved extremities............... Oscillatoria* Filaments destitute of sheaths; twisted into a regular spiral ..........................

\section{Description of Genera.}

Spirulina Turp.-Filaments unicellular, more or less motile, spirally twisted, usually surrounded by a colorless, somewhat liquid mucilage.

S. tenuissima Kütz., Fig. 291. 
Plectonema Thur.-Filaments branched, singly or in pairs, quite irregular, each filament enclosed in a separate sheath; cell contents deep blue-green.

$\cdot[P$. Wollei Farlow. $]$

Symploca Kütz.-Filaments simple or showing mere beginnings of branches; in a more or less distinct sheath, rising from a prostrate base; glued together into anastomosing or erect, wick-like clusters.

Lyngbya Ag. (Leibleinia Endlicher; Leptothrix Kütz., in part; Spirocoleus Möbius, in part).- Single filaments enclosed in distinct sheaths, either unbranched or with a suggestion of branching where the filaments break out of the sheaths. Often forming a membranous stratum.

L. sp. (?), Fig. I3.

[L. ochracea (Kütz.) Thur.]

Phormidium Kütz. (Hyphœothrix Kütz., in part; Leptothrix Kütz., in part).- A genus between Lyngbya and Oscillatoria. Filaments simple, clothed with a thin, hyaline sheath. Sheaths often become fused, and the trichomes are sometimes so numerous as to form mats on damp ground, stones, etc. The cells are sometimes constricted at the ends, and the apical cell may be attenuated or even thickened.

[P. Corium (Ag.) Gomont; P. favosum (Bory) Gomont; P. Retzii (Ag.) Gomont; P. uncinatum (Ag.) Gomont.]

Oscillatoria - Vaucher (Oscillaria Bosc.).-Filaments straight or slightly curved; only in very young specimens are they coiled; simple, without a sheath; mostly bright bluegreen, sometimes changing to violet or steel-blue. When in good condition, more or less motile, and involved in a thin mucilage. Found in all sorts of wet places, sometimes even on damp ground and in hot springs.

O. subtilissima Kütz., Fig. I.

O. 'arugineo-carulea Kütz., Fig. 2.

O. chalybea Mertens, Fig. I4.

O. amphibia Ag., Fig. I5.

O. limosa Ag., Fig. 5.

O. percursa Kütz., Fig. 6.

[O. princeps Vauch.; O. splendida Grev.; O. tenuis Ag.] 
Arthrospira Stiz.- Filaments cylindrical, commonly devoid of a sheath, and twisted into a regular spiral. The latter character is the only distinction from Oscillatoria.

A. Gomontiana Setchell.-We have not found this species, but Setchell has mentioned it as occurring in Bridgeport.

\section{SUB-FAMILY II. VAGINARIEA}

Blue-green Algæ, which lack heterocysts, and are distinguished by having one or more trichones in the same sheath. This sheath is often branched, may be lamellose and colored, or mucous and uncolored.

\section{Description of Genera.}

Microcoleus Desm. (Cthonoblastus Kütz.).- Trichomes like Lyngbya, except that two or more are often enclosed in one sheath, which is at first closed at the end, and later breaks open, sometimes dividing into shreds. The sheath is colorless, not lamellose, large, seldom indistinct.

Schizothrix Kütz. (Inactis Kütz.; Hyphæothrix Kütz., in part).- Sheaths firm, lamellose, hyaline or colored, and containing few or many trichomes.

$[S$. lardacea (Cesati) Gomont; S. coriacea (Kütz.) Gomont.]

\section{FAMILY II. NOSTOCACEE.}

Cells spherical or oval, arranged in simple chains, or, rarely, with spurious branches. The chain is imbedded in a more or less copious jelly. Some genera are provided with spores and heterocysts. The heterocysts are yellow, strawcolored, or nearly colorless, and are situated at the end of the chain, or between two vegetative cells. Their function is unknown. The dark green, granular spores divide after a period of rest, and then germinate. Many are terrestrial.

\section{Key to Genera.}

I. Filaments contorted, within a definite gelatinous tegument ............................

Filaments more or less straight, free or in a formless slimy mass, not inclosed in a tegument........ 2 
2. Heterocysts terminal, and spores contiguous with them; spores long and cylindrical...Cylindrospermum * Heterocysts not terminal ............... 3

3. Filaments aggregated without order........Anabcna* Filaments aggregated in bundles of plate-like masses

Aphanizomenon

\section{Description of Genera.}

Aphanizomenon Morren.- Trichomes a little attenuated towards the apex, glued together parallelly in dense fascicles. Cells nearly cylindrical, light blue or nearly colorless, and slightly granular. Thallus somewhat membranaceous, freeswimming, blue-green, or light pure blue, or at length olive; spores solitary, smooth, cylindrical, elongated, round at the ends, pale blue or olive.

Nostoc Vauch.- Filaments necklace-shaped, enclosed in a more or less distinct gelatinous envelope. The cells are spherical or elliptical, and more or less closely connected, with heterocysts rarely terminal. The filaments are clustered to form thalli, usually surrounded by a membrane, which is sometimes colorless, sometimes dark blue-green, dark brown, light yellow, or, most often, olivaceous.

N. minutissimus Kütz. (?), Fig. 2 II.

N.sp. (?), Fig. I8.

N. rupestre Kütz., Figs. 16, I7.

N. comminutum Kütz., Fig. I9.

[N. commune Vauch.; N. microscopicum Carm.; N. parmelioides Kütz.; N.pruniforme Ag.]

Cylindrospermum Kütz.- Filaments sheathless, single or glued together in an indefinite gelatinous stratum; occasionally a number enclosed in a tegument. Cells spherical, oblong, elliptical, or compressed. Heterocysts single, on the ends of the filaments; spores next the heterocysts very long and cylindrical.

[C. majus Kütz.]

Anabæna Bory (Sphærozyga Ag.; Trichormus Allman; Dolichospermum Thwaites).-Filaments similar to those of Nostoc, only nearly straight; rarely provided with a sheath; 
clustered in gelatinous masses, or single. Cells spherical or nearly so, some of them changing into brownish elongated spores, which are solitary, or one on either side of a heterocyst, or, rarely, in a short series. Heterocysts not terminal.

A. gigantea Wood, Fig. II.

A. Flos-aquce Kütz, or circinalis (Rab.) Kirch., Fig. I2.

[A. oscillarioides Bory.]

Anabcua is very common in reservoirs, and sometimes in combination with Microcystis is so abundant as to give the water a very bad taste and smell; and a distinct color. It is one of the most troublesome Algæ in our city reservoirs.

\section{FAMILY III. SCYTONEMACEÆ.}

This family is known by its method of branching. Each filament is enclosed in a sheath of uniform thickness, and at intervals penetrates this sheath to form long, flexuose branches which are provided with their own sheaths. The filaments are cylindrical, but thickened toward the growing end, and contain heterocysts. The sheath may be colorless, or yellow, or brown. Reproduction is usually by hormogones, though in some species spores are produced.

\section{Key to Genera.}

Branches in pairs, rising between the heterocysts

Scytonema*

Branches single, rising in the region of the heterocysts

Tolypothri..*

Description of Gencra.

Scytonema Ag. (Petalonema Berkeley; Schizosiphon Kütz., in part; Symphyosiphon Kütz., in part; Athrosiphon Kütz.).- Each filament enclosed in a sheath; branches in pairs produced by a fold of the filament, which breaks through the sheath between the heterocysts. The heterocysts are scattered irregularly throughout the filament. The filaments produce interwoven mats of larger or smaller size. The sleath is lamellose, and yellow or brown in color, generally of an even thickness, but occasionally the margins are irregular.

[S. crispum (Ag.) Bornet; S. Hofmanni Ag.: S. myoch- 
thous (Dillw.) Ag.; S. figuratum Ag.; S. ocellatum (Dillw.) Thur.]

Tolypothrix Kütz. (Hassallia Berkeley).-Filaments branched, with a distinct sheath. The branches usually appear where heterocysts occur, the trichome breaking through the sheath just below the heterocyst and continuing its growth. The sheaths are thinner than in Scytonema. The heterocysts are sometimes two, three, or four in a row.

[T. lanata (Desv.) Wartmann.]

\section{FAMILY IV. STIGONEMACEE.}

The cells of this family are arranged in a single row or in several irregular rows, in a strong, thick sheath, which is brown and very uneven. The filaments are branched, and grow by repeated division of the cells near the apex. The heterocysts are never terminal, and they are placed in a lateral position when there is more than one filament in a sheath.

\section{Key to Genera.}

Normal reproduction by means of hormogones, developed on the extremities of the branches..Stigonema* Normal reproduction by spores.......... Hapalosiphon

\section{Description of Genera.}

Stigonema Ag. (Sirosiphon Kütz.).-Cells of the filaments in one, two, or many rows, owing to the lateral division; the older filaments often having as many as ten series, while the younger have only one or two. The cells are surrounded by a membrane which is always distinct, but especially so in the older filaments. The sheath is large, irregular, and usually brown or golden yellow. The generally short, thick branches are irregularly disposed. Found mostly on damp or wet rocks, but sometimes free-floating in lakes or ponds.

[S. mamillosum Ag.; S. minutum (Ag.) Hass.; S. panniforme (Ag.) Born. and Flah.]

Hapalosiphon Näg.-Filaments attached or floating; olive-green, blue-green, or, when older, bright or dark brown. The branches rise singly at right angles to the prostrate stem, 
and sometimes bear secondary branches. The cells are granulate, and grow in a single series, rarely in two; they are distinct or, sometimes, continuous. Heterocysts are frequent. The sheaths of the branches, usually colorless, are always thinner than those of the primary filaments. Spores are formed from the ordinary vegetative cells. The plants grow in fresh and salt waters.

\section{CLASS II. BACILLARIEA (DIATOMACE无).}

We have, as yet, given no attention to the Diatoms, and they are, therefore, omitted from this report.

\section{CLASS III. HETEROKONTÆ.}

The Algæ of this class are unicellular, multicellular, or colonial, appearing as rounded single cells, filaments, or large colonies. The cell walls are usually very thick, and contain many chromatophores of a yellow-green color, without pyrenoids or starch. The ordinary asexual reproduction is by means of zoögonidia, which are pear-shaped bodies furnished with one long and one short cilium. Non-motile spores are also sometimes found with thick walls.

Sexual reproduction takes place by fusion of two similar motile gametes which probably resemble the zoögonidia in having two cilia. Since these gametes are alike they are said to be isogamous. This class contains only a single order.

\section{ORDER CONFERVALES.}

The various forms are divided into two families, as follows:-

Family i. botrydiacex. Plant body large, globose.

Family it. tribonemacex. Plant body unicellular or filamentous.

\section{FAMILY I. BOTRYDIACE 2 .}

Each plant is globose, attached by rhizoids to the damp earth; the chromatophores are numerous and the reproduction varied. This family contains only one genus, which we have not yet found in Connecticut. 
Botrydium Wall.-Small, non-cellular, green, globose plants, with colorless, much divided roots, descending into the moist earth, upon the surface of which this Alga lives. The zoögonidia are small, ovoid, and provided with a long cilium. If the plant becomes submerged, the whole may turn into a zoögonidiangium, and the zoögonidia escape through an opening in the apex. Non-motile spores are often produced in great numbers in the rhizoids. If the plant becomes too dry, the green portion migrates into the rhizoids, and a number of spores are produced.

\section{FAMILY II. TRIBONEMACE E.}

Plants unicellular or filamentous; cells spherical, cylindrical, or elongated, often united to form filaments, and spirally coiled. The cell wall is always firm, and usually thick. Asexual reproduction by zoögonidia. Aplanospores occur in Tribonema. Sexual reproduction by isogamous (i.e., similar) gametes.

\section{Key to Genera.}

I. Plants unicellular ................... 2

Plants filamentous, cell wall firm, splitting into $\mathrm{H}$ -

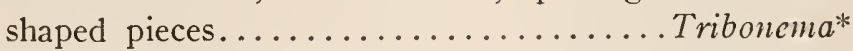

2. Cells globose, aggregated in mucilaginous colonies

Chlorobotrys

Cells elongate, usually shortly stipitate and often spirally coiled................ Ophiocytium*

\section{Description of Genera.}

Tribonema Derbes and Solier (Conferva, as used by Lagerheim). Filaments composed of cylindrical cells, covered with a thick cell wall which frequently breaks up into $H$-shaped pieces. The cells each contain one or two nuclei and several chromatophores. Asexual reproduction by zoögonidia with two unequal cilia, and by non-motile spores which escape from the broken filaments. Sexual reproduction by isogamous gametes; one of which comes to rest and rounds off before another conjugates with it.

This genus covers many of those forms previously called Conferva, a name that is now given up. Hazen places it with 
the Ulotrichacex, but we follow West in placing it here because of its yellowish-brown color. The plants are abundant in all waters.

T. bombycinum (Ag.) Derbes and Sol., Fig. 48.

T. minus (Wille) Haz., Fig. 2 I.

Chlorobotrys Bohlin.- Plants are formed of solitary globose cells, or of $2,4,8$, or 16 cells associated in a family. Each family has surrounding it an ample hyaline mucous tegument. The cell walls are thick and smooth. Six to thirty parietal chromatophores are disposed on the wall of each cell. Sometimes a red pigment spot appears in each cell.

Multiplication by cell division, at first in two rlirections, afterwards in three.

Ophiocytium Näg. (inclus. Sciadium A. Br.).-Cells cylindrical, variously curved, attenuated at one end into a thin, short stem; sometimes both ends rounded, with or without a spine. Propagation by non-motile spores or zoögonidia, which are formed by division of the cell contents. The cell wall has a lid fitted to the apex of a long tube. In the attached species the zoögonidia come to rest on the rim of the empty cell and develop into full-grown cells. A repetition of this process gives a curious branched appear ance.

O. parvulum (Perty) A. Br., Fig. 20. The two different sizes are, perhaps, two species. None of our specimens showed the terminal spine.

\section{CLASS IV. CHLOROPHYCE㞋.}

This class contains all the green Algæ and numbers more species than all the other classes of Algæ together. The forms are very diverse in size and structure, and include unicellular, filamentous, and colonial plants, some furnished with rhizoids, others with hairs, and some with spines. Cell division usually takes place in all the cells of a thallus, but occasionally there is a growing point. Both sexual and asexual reproduction are found in most of the families of the Chlorophycex. This class flourishes most abundantly in fresh water, though many are marine, and members of it are to be found in every damp or wet situation. 
The class may conveniently be divided into orders, as indicated by the following key:-

\section{Key to Orders.}

I. Thallus cœnocytic (i.e., non-cellular but with many nuclei $) \ldots \ldots \ldots \ldots \ldots \ldots \ldots$ SIPHONALES

Thallus filamentous and septate, or unicellular, or

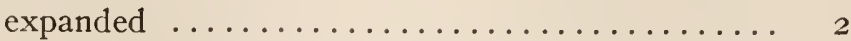

2. Thallus filamentous, though filaments may unite in a plane. In the Conjugatæ some are unicellular and not filamentous................... 3 Thallus expanded, membranous............ ULVALES Thallus neither expanded nor filamentous.......

PROTOCOCCALES

3. Cell division by intercalation of new cells producing transverse striation ............ EDOGONIALES

Cell division of ordinary type............ 4

4. Filaments attenuated and commonly ending in a

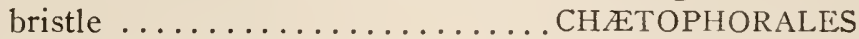

Filaments not ending in a bristle.......... 5

5. Chloroplasts single, substellate, with one pyrenoid.

Filaments may fuse in a plane:.... SCHIZOGONIALES

Chloroplasts single, reticulated or band-shaped, with-

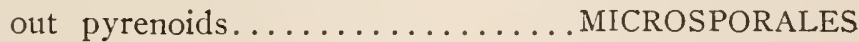

Chloroplasts numerous, parietal, each with a pyre-

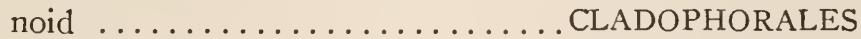

Chloroplasts single or several, large and of some definite shape, with pyrenoids. The entire contents of two cells unite to form a single zygote. . CONJUGAT \&

\section{ORDER I. PROTOCOCCALES.}

Single-celled green Algæ, without terminal growth or branches, and without vegetative generation of cells; either single or in flocks or families. Sometimes the cells of the families indefinitely increase in number, and form daughterfamilies. At other times there is a definite number associated together to form colonies called conobia. Even when apparently closely united, each cell has the power of reproduction, and therefore the plants are essentially unicellular. 
The order is a very large one, and contains an immense variety of forms which can hardly admit of a general description. The order is divided into eight families, the following six of which are known in the United States:-

\section{Key to Families.}

I. Unicellular, or of a definite number of ciliated motile

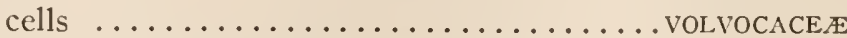

Cells not ciliated or motile............... 2

2. Cells formed in flat plates or in a network.........

HYDRODICTYACE E

Cells not in a plate or a network........... 3

3. Unicellular and solitary; cell with differentiation of

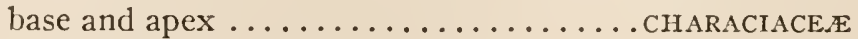

Cells without differentiation of base and apex...... 4

4. Unicellular and globular, or consisting of short, fewcelled filaments (not truly filamentous); firm cell walls; no autospores ............ PLEUROCOCCACE $x$

Cells free or colonial, without copious gelatinous envelope, forming autospores ......... PROTOCOCCACE.

Cells spherical and indefinite in number, embedded in a copious gelatinous envelope .........PALMELLACE.

\section{FAMILY I. PALMELLACE压.}

Unicellular Algæe, free-floating or attached, single or in families, with a conspicuous mucous envelope, which is without definite form, and is either structureless or differentiated into concentric envelopes. Cell contents at first homogeneous, later granular, green or reddish. Multiplication by cell division in two or three directions, and cells often grouped in twos or fours. Asexual reproduction by biciliated zoögonidia, several of which arise from an ordinary cell. Sexual reproduction has been observed in some species.

This family is divided into three sub-families, as follows:-

\section{Key to Sub-families.}

Cells grouped in twos or fours within a lamellose mucous investment ..............GLCOCYSTIDE.

Cells grouped. in fours, irregularly disposed in a mucus; cells with a non-motile hair..... TETRASPOREe 
Cells irregularly grouped within a structureless

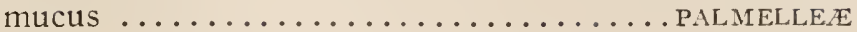

SUB-FAMILY I. GLGECYSTIDE.

Plants formed of colonies of cells in a common mucilaginous envelope. Ordinarily concentric coats of mucus can be seen around single cells or groups of cells. Multiplication by division of the mother-cell into four parts.

\section{Key to Genera.}

Colonies irregular .................. Gloocystis* Colonies cylindrical and branching.......Palmodictyon Colonies subspherical ................. Botrydina

\section{Description of Genera.}

Glœocystis Näg. (Chlorococcus Fries,, in part).Spherical or oblong cells associated in globose families of an indefinite number of cells. Teguments gelatinous, formed in layers. Cells spherical or ellipsoidal.

G. vesiculosa Näg., Fig. 28.

[G. mpestris (Lyng.) Rab.]

Palmodictyon Kütz.- The cells and surrounding tegument are in the shape of cylindrical masses which branch and anastomose. The outer covering is often hard and of a reddish brown color. Reproduction by means of resting spores with brown cell walls.

Botrydina Breb.-A genus little investigated. The colonies are subspherical, made of cells enveloped in a thick, gelatinous integument, which may be as large in diameter as five hundred microns.

SUB-FAMILY II. TETRASPOREE.

Cells grouped in fours or very irregularly scattered towards the outside of a structureless mass of jelly. The cells of this family are frequently provided with delicate non-vibratile hairs called pseudocilia.

Description of Genera.

Tetraspora Ag.- Thallus gelatinous, thick, at first baggy, then lengthening; scattered through the jelly are numberless 
green cells, dividing in one or more directions, grouped in twos or fours without order near the periphery. Isogamous planogametes - $i$. $e$., provided with cilia,- - biciliated zoögonidia, and resting spores with thick brown cell walls, are developed.

T. lubrica (Roth) Ag. var. lacunosa Chand., Fig. 2 I2.

T. gelatinosa (Vauch.) Desv., Fig. 77.

[T. bullosa (Roth) Ag.]

Apiocystis Näg.- Thallus small, of various or changing color, fastened by a stem-like base. Cells spherical, sometimes scattered, sometimes eight in a circle; contents homogeneous or slightly granular, with a distinct colorless vacuole. Propagation by globose zoögonidia, each bearing two cilia, and isogamous gametes.

\section{SUB-FAMILY III. PALMELLEX.}

A large number of globose cells are aggregated in a structureless mass of jelly, which is of indefinite extent except in Palmodactylon, in which it is more or less cylindrical and variously branched. The outer layers of the firm, thin cell walls are thrown off from time to time in one or many pieces.

\section{Description of Genera.}

Palmella Lyng. - A shapeless mass of jelly, holding cells which are spherical, oval, or oblong, green, red, or brown. Multiplication by repeated division of the cell contents, accompanied by decided gelatinization of the wall of the mother-cell. Reproduction by micro- and macro-zoögonidia and also by small isogamous planogametes.

P. mucosa Kütz. (?), Fig. 72. Fig. $72 a$ is the gelatinous colony, natural size.

Schizochlamys A. Br.- Found with Tetraspora, and like it, except that in this genus the cell wall often splits into four parts. The cell contents afterward divide into two or four daughter-cells.

Palmodactylon Näg.- Small round cells, dull green, enclosed in a cylindrical bladder-like membrane. Several of these membranes are often joined together at one end, spread- 
ing radially. One, two, or four series of cells in each membrane.

\section{FAMILY II. PROTOCOCCACE.}

The vegetative cells are green, strictly unicellular, and are not provided with cilia. Propagation either sexual or asexual. In the latter case the cells divide into many parts, the whole assuming the form of a new colony. These are called autospores and autocolonies. Division of vegetative cells lacking. In some genera the cells are united into definite regular forms called conobia, in others into a pseudocanobium, which differs from the true canobium in that the cells are not all of the same generation; other genera have the cells scattered or congregated into irregular forms.

Key to Sub-families.

I. Cells elongated, frequently curved; solitary or in definite, loosely coherent colonies........SELENASTRE $\overline{\text { E }}$

Cells angular, with a definite number of angles, two, four, six, eight, or more; cells solitary...TETRAEDRE $x$

Cells variable, united in a regular flat plate. . CRUCIGENIE.E

Cells globose or sub-globose.............. 2

2. Cells strictly globose, united in a spherical colony (cœnobium) $\ldots \ldots \ldots \ldots \ldots \ldots \ldots$ cELLASTRE.æ

Cells globose or sub-globose, not united in a spherical cœnobium ....................... 3

3. Cells with two or more attenuated bristles...PHYTHELIE

Cells without bristles................. 4

4. Cells generally retained within enlarged wall of mother-cell ................... ö̈cystide

Cells joined in colonies by persistent walls of mothercells, which sometimes become transformed into connecting threads............. DICTYOSPH ÆRIE.£

\section{SUB-FAMILY I. DICTYOSPHÆRIEÆ.}

Cells globose, ovoid, or ellipsoid, and associated to form indefinite colonies. The cells are held in position, usually, by the wall of the mother-cell, which in some genera breaks up into connecting threads. Multiplication by simple vegetative 
division, or by the formation of four daughter-cells in a mothercell, which at length ruptures to let them out.

\section{Key to Genera.}

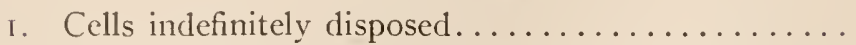

Cells in grape-like clusters, freely exposed in a thin gelatinous envelope............ Botryococcus

2. With well-marked, subdichotomous connecting threads ; chloroplast parietal.........Dictyospharium* Cells in radiating series; connecting threads scarcely visible; chloroplast axile............. Dictyocystis

\section{Description of Genera.}

Botryococcus Kütz.- Sixteen or thirty-two cells clustered like a bunch of grapes in an irregularly lobed mucous thallus. Cells oval, spherical, or elliptical, densely packed in families within a thin tegument. Clusters free-swimming, green, at length pallid or brown.

Dictyosphærium Näg.-Cells green, kidney-shaped or egg-shaped, gathered into a hollow, somewhat spherical family, and usually surrounded by a gelatinous envelope; free-swimming. Cells covered by thick coats which are confluent; joined by a fine tegument. Division of cells at first in all directions, later only radially. Biciliated zoögonidia rarely occur.

\section{Ehrenbergianum Näg., Fig. 22.}

Dictyocystis Lagerh. - Oblong or cylindrical cells, held in radiating series by delicate threads, to form a small. freefloating colony, the series often branching.

\section{SUB-FAMILY II. TETRAEDREÆ.}

Solitary unicellular plants, flattened and angular with a definite number of angles. The angles may be rounded, notched, or furnished with spines. Only one genus, sometimes divided into two, according to the depth of the lobulation.

Tetraedron Kütz. (Polyedrium Näg.).-Cells green, single, free-swimming, three-, four-, or eight-angled; angles rounded, sometimes notched, mostly armed with a spine. 
Propagation by means of autospores, which are formed, usually to the number of four or eight, in the mother-cell.

T. minimum (A. Br.) Hansg., Fig. 23.

T. trigonum var. punctatum (Kirch.), Fig. 24.

T. trigonum var. pentagonum (Rab.), Fig. 25.

\section{SUB-FAMILY III. OÖCYSTIDEæ.}

Cells spherical or elliptical, often retained within the swollen wall of the mother-cell. There may be one or several parietal chloroplasts. The cell wall of all but Palmellococcus is firm. Multiplication by means of autospores, which often develop and grow to full size in the mother-cell.

\section{Key to Genera.}

I. Cells curved, subcylindrical or sublunate. .Nephrocytium* Cells ellipsoidal ......................öcystis Cells spherical ...................... 2

2. Cells large, solitary and free-floating.... Eremosphara Cells minute, forming a thin stratum....Palmellococcus*

\section{Description of Genera.}

Nephrocytium Näg.-Two, four, eight, or sixteen oblong or kidney-shaped cells, associated in a free-swimming family, surrounded by an oval or kidney-shaped covering. Of variable size; cells bright green. Frequent in ponds. Multiplication by autospores, which are often spirally disposed around the inside of the wall of the mother-cell.

N. Nagelii A. Br., Figs. 26, 29.

N. Agardhianum Näg., Fig. 27.

Oöcystis. This genus differs from Nephrocytium in having cells ellipsoidal and showing polar nodules. There are usually several parietal chloroplasts in each cell.

Eremosphæra D. By. (Chlorosphæra Henfrey).-Large, spherical, free-swimining cells, with firm walls, showing a colorless border. Cell contents green, granulose; each cell containing large numbers of small parietal chloroplasts. Multiplication into two or four parts, which escape through the cell wall. Found in small pools. 
Palmellococcus Chodat (Protococcus Ag., in part).Strictly unicellular Algx, globose, green, sometimes changing to red upon exposure. Cells formed singly or in clusters, growing in water, or on damp soil, flower-pots, trunks of trees, etc.; $8,16,32$, or 64 spores formed within a mother-cell, the wall of which ruptures and sets them free. Very rapid multiplication by cell division.

P.sp. (?), Fig. 30.

P. Gigas (Kütz.), Fig. 3I.

\section{SUB-FAMILY IV. SELENASTREE.}

Cells elongated and attenuated, sometimes lunate; solitary, or joined into fragile families. A single chloroplast, which may contain one or many pyrenoids, is found in each cell. The cell wall is delicate but firm. Multiplication by autospores or attocolonies.

Key to Genera.

I. Colonies enveloped in mucus..........Kirchnericlla* Colonies almost destitute of mucus........... 2

2. Cells attenuated to acute apices........... 3

Cells sublunate or ellipsoidal, arranged in groups of four in a plane; groups forming irregular colonies

Dimorphococcus

3. Cells forming definite colonies of a row of cells in one

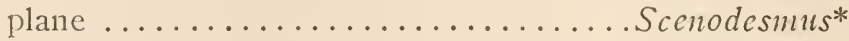
Cells solitary or loosely grouped in irregular bundles Ankistrodesmus* Cells lunate, arranged back to back.......Selenastrum* Cells dividing, oblique; daughter-cells remaining attached loosely by their apices.......... Dactylococcus

\section{Description of Genera.}

Kirchneriella.-The cells are bent like a bow, often until their apices almost touch each other; loosely aggregated within an enveloping mass of jelly. The cell wall is thin, the chloroplast parietal; multiplication by autospores, four or eight of which are produced in a mother-cell. The genus differs from Selenastrum in the presence of jelly.

K. obesa (West) Schmidle, Fig. 54 . 
Selenastrum Reinsch.-Cells lunate, attenuated on both ends to a fine point, with firm, thin walls; arranged back to back to form four-to eight-celled colonies. Multiplication by autospores.

S. acuminatum Lagerh., Fig. 46.

S. sp. (?) (perhaps acuminatum), Fig. 43 .

Scenodesmus Meyen.- Cells elliptical, cylindrical, oblongspherical, often drawn out into longer or shorter spines. One, sometimes two, rows of cells are commonly joined laterally into a cœnobium. Propagation by repeated division of the cell contents into brood-families, which are set free by rupture of the mother-cell wall.

S. obtusus Meyen, Fig. 38 .

S. caudatus Corda, Fig. 36 .

S. caudatus var. abundans Kirch., Fig. 32.

S. caudatus var. typicus Kirch., Fig. 33 .

S. caudatus var. setosus Kirch., Fig. 34 .

S. acutus Meyen, Fig. 37 .

S. dimorphus Kütz., Figs. 42, 44.

S. antennatus Breb. var. rectus Wolle, Fig. 39.

S. sp. (?), Fig. 35 .

Dimorphococcus A. Br.-Cells united more or less in fours on short branches; the two intermediate, contiguous cells oblique, obtuse-ovate; the two lateral, opposite and separate from each other, lunate; families free-swimming, in irregular clusters.

Ankistrodesmus Corda (Rhaphidium Kütz.; Schröderia Lemmermann).- Finely granulate, cylindrical cells, usually tapering at both ends and variously curved. The cells occur singly, or gathered into groups, several radially joined, two crossing each other, rarely two united at the end; covering thin and smooth; division in only one direction.

A. falcatus (Corda) Ralfs, Fig. 45 .

A falcatus var. acicularis West, Fig. 47.

A. falcatus var. mirabilis West, Fig. 4I.

A. Braunii (Näg.) (?), Fig. 40 .

SUB-FAMILY V. CRUCIGENIEÆ.

Cells gathered into flat cœnobia. The cells are generally rounded and sometimes furnished with spines. The groups of 
four are held together by a tough mucilage. Multiplication by autocolonies. The only American genus is the following:-

Crucigenia Morren (Staurogenia Kütz.; Lemmermannia Chodat; Willea Schmidle).-4, 8, I6, or 32 subquadratic cells, gathered into a flat cœnobium held in a mucilaginous envelope. As many as 128 cells in groups of four have been discovered. The cell walls are smooth, and each cell is furnished with a single chloroplast. Multiplication by autocolonies.

\section{SUB-FAMILY VI. PHYTIIELIEE.}

Unicellular or grouped in a more or less definite cœnobium, freely floating. Almost devoid of a mucous envelope and furnished with bristles.

\section{SUB-FAMILY VII, CELASTRE.}

The cells are either globose or polygonal, provided with processes by which they are united into a hollow sphere; or broadly lunate, and united at the centre by short stalks. Propagation by autocolonies which are formed in each cell of the cœnobium.

Key to Genera.

Cœnobium hollow ...................... colastrum*

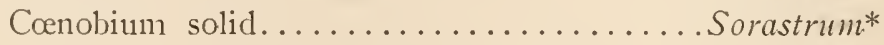

\section{Description of Genera.}

Cœlastrum Näg. (Hariotina Dang.)._Cœnobium a hollow globe formed of a single layer of green, spherical or angular cells; later the cœnobium appears to be reticulately pierced; in older growths the cells have become polygonal through continued pressure. Daughter-cœnobia are developed within the mother-cell, and escape by breaking the walls of the latter. Found in ponds.

C. microporum Näg., Fig. 51.

Sorastrum Kütz. (Selenosphærium Cohn)._- Differs from Colastrum in that the conobium is solid. It is composed of $4,8,16$, or 32 wedge-shaped stalked cells, radially disposed, with spines (usually two) on each end. Propagation by autocolonies. 
S. spinulosum Näg. (?).- The common form of Sorastrum in this region is shown in Fig. 213. It shows only one spine at each corner. A less common form which may be a different species is shown in Fig. 55.

\section{FAMILY III. HYDRODICTYACEI.}

These plants are free-floating, non-motile cœnobia, composed of cells arranged like a net or in a flat plate. Pediastrum may have fifty cells and $H_{y}$ drodictyon many hundreds. Multiplication by autocolonies. Reproduction by spores, which become quiescent within the mother colony and then unite by their extremities to form a new cœnobium. A fusion of isogamous gametes to form a zygospore also sometimes occurs. The two sub-families are probably not closely related.

\section{Key to Sub-families.}

Cells in a flat plate................. PEDIASTRE. Cells form a network.............. HYDRODICTYE $\approx$

\section{SUB-FAMILY I. PEDIASTREA.}

Microscopic plants composed of a number of small cells united into a flat disk. Zoögonidia formed in the mother-cell are liberated into an external vesicle, and there form new cœnobia.

\section{Description of Genus.}

Pediastrum Meyen.- The plane, discoid or stellate, freeswimming cœnobium is tormed of a single, rarely a double, layer of green cells, perforated or continuous. The cells are polygonal, with four or more sides; the central cells are entire, while the marginal cells are often bilobed; the lobes are wedge-shaped, simple or bidentate, sometimes drawn out into hair-like ends. The genus is very abundant and variable. The reproduction is as follows:- The cell contents are at first homogeneous, later becoming granular. The granular contents divide into small zoögonidia, spherical or nearly so, which break away from the mother-cell into an external vesicle. After they have been motile awhile, they come to rest, and then divide and redivide; a gelatinous covering forms around them, the cells arrange themselves into a single layer, and gradually take on the shape of the mother plant. Autocolonies 
are sometimes found in a single cell. Biciliated gametes are also found which conjugate.

P. sp. (?), Fig. 65 .

$P$. pertusum Kütz., Figs. 66, 68, 70, 7 I.

$P$. pertusum var. clathratum A. Br., Figs. 50, 52, 57 .

P. tetras Ehrb., Fig. 69.

P. Borjanum (Turp.) Nenegh. var. granulatum Kütz., Figs. 58, 59, 67.

P. Ehrenbergii A. Br., Figs. 61, 62, 63, 64.

SUB-FAMILY II. HYDRODICTYE.E.

Plants large, composed of a number of large cells, which are so arranged as to form a net. Zoögonidia swarm and become quiescent within the mother-cell, and there unite to form new cœnobia.

Hydrodictyon Roth.-Cœnobium large, composed of oblong cells joined at the ends, forming a reticulated stratum, at first baggy, then net-like. All the cells are fertile, breaking up to form large numbers of microgonidia within the mothercœnobium. After a period of activity they come to rest and form a new cœnobium by joining together at their extremities. Sometimes they become perfectly dry; but, when moistened, they form biciliated macrogonidia which join themselves into daughter-cœnobia within the mother-cell. Motile gametes are also found which become free and conjugate into a globose zygote. The only known species is the following:-

H. reticulatum (L.) Lag., Figs. $2 \mathrm{I}_{5}, a, b, c$.

FAMILY IV. PLEUROCOCCACEA.

Plants mostly unicellular, sometimes composed of short, creeping, slightly branched filaments, which are never attenuated to hairs. The cell walls are generally very firm, and the cells aggregate to form indefinite colonies. Multiplication by division in two or three directions. Asexual reproduction sometimes by means of biciliated zoögonidia. Of the six genera of this family we have found only one.

Pleurococcus Menegh. (Protococcus Ag., in part; Cystococcus Näg.; Chlorococcus Fries, in part; Pseudopleurococcus Snow).- The cells are usially globular, sometimes angular from pressure. Division occurs in three direc- 
tions, so at times a cubical colony is seen, which easily divides into its respective cells. The plants are occasionally creeping, branched filaments. A single parietal chloroplast is present, with or without a pyrenoid. Reproduction by aplanospores $i$. e., without cilia, - by rejuvenescence of the mother-cell contents, by isogamous gametes, or by biciliated zoögonidia.

$P$. vulgaris Menegh., Fig. 73, is a very common form in the state, growing in damp places, upon stones, etc. We have not found it in water.

\section{FAMILY V. CHARACIACEX.}

Plants unicellular, usually elongated and attenuated at both ends, the lower end terminating in a stalk, generally furnished with a disk by which it is attached to larger Algæ. A single parietal chloroplast with one pyrenoid is present. Reproduction by numerous zoögonidia formed by division of the cell contents at first transversely, then longitudinally. These portions become rounded off, become biciliated, and escape by a lateral, or, more rarely, a terminal pore. Each zoögonidium becomes a new plant on coming to rest.

Characium A. Br.- Coextensive with the family.

C. Nagelii A. Br., Fig. 53 .

C. ambiguum Herm., Fig. 56.

FAMILY VI, VOLVOCACEA.

Plants unicellular, or consisting of conobia with a definite number of cells, always ciliated and motile. Multiplication by division of the mother-cell into 2 , 4 , or 8 daughter-cells. Reproduction both by the union of isogamous planogametes and, in the higher genera, by heterogamous gametes.

The Volvocacex are sometimes found in immense quantities, and frequently give an oily taste and odor to drinking water. They are closely related to the Flagellata, and some of them are frequently classed with the Protozoa.

Key to Sub-families.

Composed of colonies of many cells; cells with two

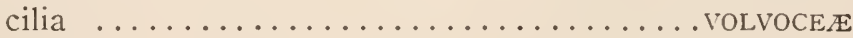

Composed of single cells with two, or rarely four,

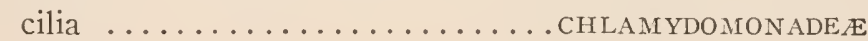




\section{SLIBFAMIIY I. VOLYOCE.E,}

Notile conobia; cells varying in number from 4 to 20,000 , globose or ovoidal, with a distinct but thin cell wall: cilia two; chloroplast one of very variable form, usually including a single pyrenoid. Cells usually imbedded in a conmon mucilaginous investment; more rarely united by protoplasmic processes. All the cells may be capable of reproducing the plant, or there may be a differentiation into regetative and reproductive cells. Vegetative reproduction by division of some or all of the cells to form daughter-conobia. Isogamous or heterogamous sexual reproduction.

\section{Key to Genera.}

I. Colonies spherical or circular ............ 2

Colonies flat, cells 4-16, angles rounded, in a color-

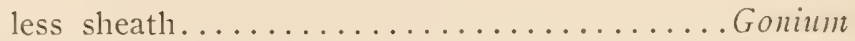

2. No gelatinous covering, cells many, in a hollow globe

Tolvo $x^{* *}$

No gelatinous covering, cells 16 , arranged in four rows ...............................

With a gelatinous covering.............. 3

3. Colony ovate or spherical............... 4

Colony of eight crlls, in an equatorial zone in a spherical or ellipsoidal investment.... Stephanosphara

4. Cells 16-32, globose, not crowded, but scattered at regular intervals on a colorless sphere...... Eudorina* Cells 8, I6, 32, or 64, globose, crowded, often angular

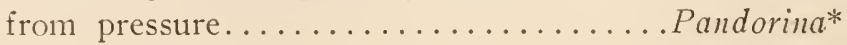

\section{Description of Genera.}

Gonium Müller (inclus. Tetragonium WVest).-Four to sixteen cells so placed in a flat stratum as to form a quadrangle with rounded angles. A colorless tegument covers all. Cells globular except when angular from pressure. The cilia all arise from one surface of the colony. When old, the cells become granular and are connected by produced angles. Reproduction by repeated division of the cytoplasm into zoögonidia. Multiplication by daughter-conobia formed in each cell of the mother-cœnobium. 
Volvox Ehrb.--Cœnobium spherical, hollow, the surface composed of green cells estimated as high as 22,000, arranged regularly on the wall, and each provided with two cilia, which reach through the gelatinous covering and keep the cœnobium in constant motion. Each green cell is attached to the six surrounding ones by fine threads which are difficult to see even under high power and with favorable light. Ö̈gonia and antheridia are developed from vegetative cells, and a brown, smooth or star-shaped cell is often found which is supposed to be a fertilized oöspore in a resting stage. Asexual reproduction takes place by the division of the larger vegetative cells, which form new families. These after sufficient growth separate from the mother-cell and begin life independently.

$V$. aureus Ehrb., Fig. 75 .

$V$. globator (L.) Ehrb., Fig. $76 . \quad$ Fig. 74 is a fertilized oöspore. These are frequently found within the cœnobia, and also occur free in the water. Ehrenberg named it $V$. stellata, but of course this was an error.

Spondylomorum Ehrb. (Uvella Ehrb.; Phacolomonas Stein.).- Cœnobium of sixteen cells in four alternating rows, each cell with four cilia.

S. quatemarium Ehrb., Fig. 288.

Stephanosphæra Coln11.-Eight green cells, each having two vibrating cilia, are arranged at regular intervals in an equatorial circle, enclosed in a colorless sphere. Propagation by macrogonidia, formed by eight-fold division of the green cells, each bearing two cilia and a lateral red spot, and gathered into families of eight; or by microgonidia, each provided with four cilia, formed by repeated division, and at first revolving within the common sphere, afterwards escaping singly. In hollow rocks and pools after rain.

Eudorina Ehrb. (Eudorinella Lemmermann).- Cœnobium somewhat oval or spherical, composed of 16 or 32 globular green cells, each with two cilia, arranged around the colorless sphere at nearly regular intervals. Usually four of the 32 cells develop antheridia and the rest oögonia for the sexual reproduction. Asexual reproduction by the division of the cells into 16 or 32 parts to form daughter-cœnobia.

E. elegans Elirb., Fig. 285. 
Pandorina Bory.-Conobium spherical, covered by a colorless jelly. Cells 8, 16, or 32, green, spherical, each covered with a thin membrane and furnished with two widely divergent cilia, often so crowded as to be angular. Propagation sexual, by the conjugation of isogamous gametes. Cells of a cœnobium divide into eight daughter-cells; these become two-ciliated gametes, and are scattered and conjugate with similar cells from other cœnobia; they flow together and produce a zygospore, which, after a season of rest, develops one to three biciliate macrospores, and these in their turn develop new cœnobia. Asexual multiplication by formation of a datightercœnobium from each of the cells of the mother-cœnobium.

P. morum (Müll.) Bory, Figs. 286, 287.

\section{SUB-FAMILY II. CHLAMYDOMONADER.}

The plants are unicellular, spherical or ovoid, with thin walls, and two or rarely four cilia. The chloroplast is in the posterior end of the cell and usually contains one pyrenoid. Reproduction by division of the resting cell into 2,4 , or 8 daughter-cells. Non-motile spores sometimes occur. Sexual reproduction by conjugation of ciliated gametes, either isogamous or heterogamous, which are similar to the vegetative cells, though smaller. Tley arise by division of the contents of the mother-cell, sometimes as many as 64 resulting from one cell.

$$
\text { Key to Genera. }
$$

Contents of cell close to cell wall......Chlamydomonas* Contents of cell connected with cell wall by threads

Spharella

\section{Description of Genera.}

Chlamydomonas Elirb.-- Vegetative cells ovate, green, enclosed in a narrow, colorless tegument, frontal extreme sometimes produced to a beak with two cilia, other end with large chloroplast, and with or without a red lateral spot. Gametes formed by continued division of cell contents of vegetative cells, numerous, oblong, or ovate, pale green or yellow, afterwards brownish. Zygospores globular, red or brownish.

Chlamydomonas is abundant in the reservoirs of the state. C. pulvisculus Elirb., Fig. 289. 
According to West the forms with four cilia should be named Carteria, Fig. 290. Both the two- and the four-ciliate forms are common in our waters.

Sphærella Sommerfeldt (Chlamydococcus A. Br.; Hæmatococcus Ag.).-Like Chlamydomonas, except that the cell walls are outstanding and joined to the cell contents by fine threads. There is always more or less red coloring matter present.

[S. lacustris (Girod.) Witter.]

\section{ORDER II. ULVALES.}

Thallus expanded and parenchymatous; attached when young by rhizoids. Each cell is furnished with a single nucleus and a parietal chloroplast, often quite large, containing one pyrenoid.

\section{FAMILY I. ULVACEA.}

Most of the genera of this family are inhabitants of salt or brackish water. The thallus consists of an expanse of cells arranged compactly with their longer axes at right angles to the plane of the thallus; either flat or, more rarely, tubular. The cells are uninucleate, with a single parietal, often ragged, chloroplast, containing one pyrenoid.

Asexual reproduction by zoögonidia with 4 cilia, and by gemmæ. Sexual reproduction by isogamous gametes. The contents of a vegetative cell divide into 8 (sometimes 4 or 16 ) gametes, smaller than the zoögonidia, which are pear-shaped, with a pigment spot and two long cilia. As a result of conjugation a rounded cell with two pigment spots and 4 cilia is formed, which becomes a zygospore on losing its cilia.

Enteromorpha Lk.-Thallus tubular, membranaceous; at first fixed, then floating; sometimes branched. It is either green or pale olive-colored. Reproduction as in the family. Found in salt or fresli water.

\section{ORDER III. SCHIZOGONIALES.}

The thallus, often attached by rhizoids, is filamentous, sometimes several filaments being joined laterally to form a flat 
plate. Each cell contains one nucleus and a central stellate chloroplast with one pyrenoid. The cells, especially of young plants, often divide in two or three directions.

\section{FAMILY I. PRASIOLACEE.}

Coextensive with the order.

Prasiola Ag. (inclus. Schizogonium Kütz., and Hormidium Kütz., in part).- Found on moist earth, trunks of trees, rocks, stones, etc.; some species require very little moisture. The cells of the filamentous thallus are broader than long, and those of the flat plates quadrate or polygonal. The cell walls are strong and colorless. Reproduction by gemmæ, by resting spores liberated at the margin of the thallus, and by tetraspores.

\section{ORDER IV. CHETOPHORALES.}

Thallus filamentous, simple or usually branched. Branches generally attenuated and bearing long hairs. The uninucleate cells possess each, except in Trentepohliacec, a single parietal chloroplast with one or more pyrenoids. Asexual reproduction by resting spores or zoögonidia with two cilia. Sexual reproduction by isogamous planogametes with two cilia, or by heterogamous gametes.

\section{Key to Families.}

I. Plant entirely filamentous, simple........... 2 Plant of branched filaments forming a flat cushionlike expansion enveloped in mucilage..........

COLEOCH ETACEE

2. Filaments branched.................. 3

Filaments not branched ............... 5

3. Gametes arise from special cells only...........

TRENTEPOHLIACE.E

Gametes arise from any cell of the filament...... 4

4. Small creeping filaments upon water plants; cells globose or cylindrical ........... HERPOSTEIRACE

Like the above, but with flask-shaped cells.......

CH.ETOSPH ERIDIACEX

Plant not creeping................... 
5. Cells with thick lamellose coats, in a series inside a lamellose sheath .............. CYLINDROCAPSACE.E Cells without lamellose coat.......... ULOTRICHaCE E

\section{FAMILY I. TRENTEPOHLIACE.E.}

Thallus filamentous and branched, filaments erect or creeping, growing on the ground or on tree trunks. The cell walls are firm and lamellose. The cells are uninucleate, and possess one or many parietal chloroplasts with or without pyrenoids. The color of the plants is usually brown or reddish. Zoögonidia are developed only in cells especially set apart, either on the ends of the branches or intercalated. These motile spores sometimes conjugate. Spores are sometimes produced which rest for a period before germinating, called resting spores or hypnospores.

\section{Key to Genera.}

Terrestrial or arboreal; chloroplasts several......

Trentepohlia*

Aquatic; cells that produce zoögonidia are terminal

Gongrosira

Aquatic; cells that produce zoögonidia not terminal

Leptosira

\section{Description of Genera.}

Trentepohlia Mart. (Chröolepus Ag.).-Filaments irregularly branched, often so dense that the branches and stem cannot be easily distinguished; primary branches and stem of same thickness. Cell contents reddish brown, goldenyellow, or olive-colored. About 32 red-brown or golden-yellow zoöspores in a cell which is set apart especially for the purpose, usually on the end, sometimes on the side of the filament.

[T. anrea (L.) Mart.; T. Iolithus (L.) Wittr.]

Gongrosira Kütz. (inclus. Pilinia Kütz., in part).- The plant is attached by a mass of cells, formed by a confluence of creeping branches. From this mass, which may be of one or many layers of cells, numerous erect branched filaments arise. The whole is frequently encrusted with lime. The cell walls are thick and lamellose, and the chloroplast is parietal with one or many pyrenoids. Zoögonidia are found in flask- 
shaped, terminal zoögonidiangia. The spores are ordinary cells from the recumbent branches which become detached.

Leptosira Borzi.- Very much like Gongrosira. The thallus is in the form of a minute bright green cushion. The cells are light yellow-green, the terminal cells being elliptical or irregtular. The zoögonidiangia are intercalated and not terminal. The zoögonidia either germinate directly, or conjugate in pairs and form resting spores. The ends without cilia fuse first in conjugation.

\section{FAMILY II. CHÆTOPHORACEX.}

The thallus is branched, and the branches are attenuated sometimes into long hyaline hairs; it is usually differentiated into creeping and erect portions. The creeping portion is attached by rhizoids, is branched, and is more or less torulose. The cells of the creeping portion are more or less swollen, and the branching is irregular. Each cell, except those of the terminal hairs, is provided with a parietal irregular chloroplast, containing a single pyrenoid.

Zoögonidia, from I to 16 , may be produced in each cell of the thallus except those of the rhizoids and the terminal hairs. They possess a red piginent spot and 2 or 4 cilia, and vary much in size. Spores of a red-brown color are produced in all the genera of the Chætophoraceæ. The gametes possess only two cilia, conjugate in pairs, and produce zygospores which rest for a short period before germinating.

\section{Key to Genera.}

I. Plants less than I mm. high, without setæ..... Microthamnion*

Plants larger, branches attenuated, and with setæ... 2

2. Filaments fine, showing little difference in character of stem and branch, not in tufts in gelatinous

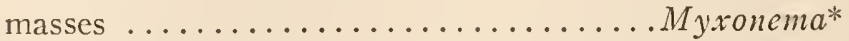

Filaments fine, in tufts in a dense gelatinous substance

Chatophora*

Filaments and main branches large, bearing tufts of small branchlets................ Draparnaldia* 


\section{Description of Genera.}

Microthamnion Näg.- Filaments articulate, variously branched, straight; end cell at first linear, then obtuse, and finally swollen into a sporangium. The plants are at first fixed, but later free-floating. The branches arise just below a transverse cell wall. The chloroplast is parietal, long and entire, and lacks a pyrenoid.

This genus is frequently placed with the Trentepohliacce; but Hazen states that the zoögonidia may be produced in any cell of the filament, and hence it has its relationship near My.ronema. Two species are found in Connecticut, according to Hazen.

\section{[M. Kuetzingianum Näg.; M. strictissimum Rab.]}

Myxonema Fries (Stigeoclonium Kütz.).-Filamentous, simple, branched, articulate; the branches not in tufts, in appearance nutch like the main stem, with the end cells often drawn out into long, colorless bristles. The chloroplasts are scattered or arranged as in Drapanaldia. One to many zoögonidia, each with two or four vibrating cilia, formed from the contents of one cell. Gametes with 4 cilia. Zygospores smooth or stellate.

M. attenuatum Haz., Fig. 220.

1. tenue (Ag.) Rab., Figs. 79, 82.

M. nanum (Dillw.) Haz., Fig. 284.

M. lubricum var. varians Haz., Fig. 81.

M. sp. (?), Fig. 78 .

[M. flagelliferum (Kütz.) Rab.]

Chætophora Schrank.- Plants enveloped in a hard, gelatinous covering of a globose, plane or lobed form. Thallus filamentous, articulated and branched. Stems radiately disposed, dividing into short branchlets, sometimes ending in a bristle. The zoögonidia have two or four cilia, and resting spores are generally developed from terminal cells and are brown.

C. incrassata (Huds.) Haz., Fig. 22I.

C. pisiformis (Roth) Ag., Fig. 222.

[C. attenuata Haz.]

Draparnaldia Ag.- Filaments articulate, much branched. The stem is thick and composed of sterile cells, colorless 
except for the chloroplast, which is in the shape of a transverse band. The filaments are furnished more or less densely with alternate or opposite, tufted branches. These are composed of smaller, green, fertile cells, the end cell often a colorless spine. From one to four zoögonidia, with four cilia apiece, arise from each cell of the lateral branches. Usually all the cells of one tuft form zoögonidia at the same time, and the whole process occupies but a few minutes. A gelatinous sheath, soft and slippery, covers the whole. Found in clear streams, attached to stones or water-plants.

D. plumosa (V'auch.) Ag., Figs. 83, 84.

D. glomerata (Vauch.) Ag., Fig. 217.

[D. acuta (Ag.) Kütz.]

\section{FAMILY III. CYLINDROCAPSACEE.}

Filamentous green Algæ, without branches or roots, living either in water or air. The filaments are covered with a thick, lamellose sheath, and the cells are lamellose and are in a single series.

In an ordinary vegetative cell the contents mass together to form one oösphere. The antherozoids, which cliange from green to red or orange, are each provided with two short cilia. After the oosphere is fertilized, it also changes to red or orange, and lies resting for some time before it germinates.

Cylindrocapsa Reinsch.- With the characters of the family. They are at first attached, then floating.

\section{FAMILY IV. ULOTRICHACE. E.}

Filaments simple, composed of cylindrical or of rounded cells. The cell wall is always colorless, though of varying thickness. Each cell contains a single parietal chloroplast with irregular margins and one pyrenoid. Asexual reproduction takes place in various ways. Both motile and non-motile spores are produced; of the former some are large (macrozoögonidia) and some small (microzoögonidia). The plants also multiply by dismemberment of the filament into single cells or series of cells. Sexual reproduction by isogamous gametes. 


\section{Key to Genera.}

Filaments attached; chromatophore a homogeneous zonate band, with one to several pyrenoids... Ulothrix*

Filaments not attached; chromatophore a parietal disk or plate, with one pyrenoid........Stichococcus* Filaments generally not attached; chromatophore granular, covering more or less completely the whole cell wall, containing starch but no pyrenoids

Aicrospora*

Description of Genera.

Ulothrix Kütz. (Hormiscia, as used by Rabenhorst, Hansgirg, and De Toni).- Filaments simple; each cell except the basal cell capable of reproduction. The chloroplast is parietal with one or many pyrenoids. Asexual reproduction by zoöspores. Sexual reproduction by conjugation of gametes, of which eight or more may be formed in a cell.

U. zonata (Web. and Mohr) Kütz., Fig. 94.

U. tenerrima Kütz., Fig. 93.

Figures 86 to $9 \mathrm{I}$ are specimens of Ulothrix of which we have not determined the species.

[U. implexa Kütz.; U. flacca (Dillw.) Thur.]

Stichococcus Näg. (Hormococcus Chodat).- Very like Ulothrix, but unlike it in being almost wholly aerial, and in the fact that the filaments easily and commonly dissociate into cylindrical cells or small groups. The dissociation frequently occurs first on the one side and then on the other, giving a zig-zag appearance. Each cell has a parietal chloroplast, usually occupying a part of the cell wall and containing a small pyrenoid. Propagation by cell division, breaking up of the filaments, by non-motile spores, and by biciliated zoọgonidia.

S. flaccidus (Kütz.) Gay, found but not figured.

[S. rivularis (Kütz.) Haz.]

Microspora Thur.-Filaments composed of cylindrical or slightly swollen cells. The firm, sometimes lamellose cell walls occasionally break up into $\mathrm{H}$-shaped pieces, each piece composed of a transverse wall and portions of the lateral walls of the two adjoining cells. The cells are uninucleate, and a more or less reticulated chloroplast occupies the cell wall. 
Resting spores with thick walls are produced, usually one in each cell, and also two- to four-ciliate zoögonidia.

M. Wittrockii (Wille) Lag., Fig. 216.

M. Stagnorum (Kütz.) Lag., Fig. 92.

[M. abbreviata (Rab.) Lag.; M. amœna (Kütz.) Rab.; M. crassior (Hansg.) Haz.]

FAMILY V. HERPOSTEIRACE

The thallus is a creeping filament, sometimes branched, and growing on larger Algæ or other water plants; most of the cells have a bristle on the back, which is bulbous at the base and separated from the cell by a septum.

In the sexual reproduction, cells in the centre of the thallus, devoid of bristles, form the oögonia. One oösphere is formed in each ooggonium, and is ejected through an opening in the wall. The oösphere is large and slowly motile, provided with four cilia. Smaller cells on the end of the thallus, frequently colorless, form the antheridia. One or two swiftly moving antherozoids, pear-shaped, each with four cilia and two pulsating vacuoles, are produced in each antheridium, and they unite, outside the oögonium, with the oösphere.

Herposteiron Näg. (Aphanochæte A. Br., Berth., Huber).-Coextensive with the family.

H. Confervicola Näg., Fig. $8 \mathrm{ob}$.

[H. vermiculoides Wolle.]

FAMILY VI. CH ETOSPH ERIDIACEE.

Thallus creeping, composed of flask-shaped cells more or less loosely joined, and each bearing a very long and slender seta, sheathed at the base. Cell division horizontal, the lower daughter-cell migrating to the side.

Asexual reproduction by zoöspores, formed to the number of four or more (?) in a cell.

Chætosphæridium Klebahn.-Coextensive. with the family.

\section{FAMILY VII. COLEOCHETACEE.}

Small, bright green water-plants. The thallus forms small green cushions or discs. The cells in the common species often 
form a flat, more or less circular plane, or are arranged as filaments radiating from one point. The cells are oblong, more or less dilated at the anterior end, and some of them bear a colorless bristle fixed in a long and narrow sheath.

The oögonium is round, on a slender neck - the continuation of the end cell of the plant. Antheridia found either on a neighboring cell or on a separate thallus. The oöspore rests for the winter, and develops in the following spring. Asexual reproduction by zoögonidia, which are larger than the antherozoids and may be developed in any cell.

Coleochæte Breb.-Coextensive with the family.

C. irregularis Pringsh. (?), Fig. 80a.

C. scutata Breb., Fig. 243 .

\section{ORDER V. GEDOGONIALES.}

Thallus of simple or branched filaments, fixed. The cells are uninucleate, and with a parietal, more or less anastomosing chloroplast containing one or more pyrenoids. In the vegetative division new pieces of the cell wall are intercalated. The zoögonidia are possessed of a circle of numerous cilia around the anterior end. Antheridia and oögonia are present.

\section{FAMILY I. EDOGONIACEE.}

Filaments branched or unbranched, attached in early stages. Cell multiplication by transverse division, shown by transverse strix, usually at the end of the mother-cell.

The oögonia are deveioped in a series of vegetative cells, and are at first green, then orange, and finally dark red or almost black. There are two kinds of male plants, dwarf and elongated; the dwarf males are attached to female plants, and the elongated males are composed of a short series of cells forming an independent thread.

Asexual reproduction by zoögonidia. The entire contents of a cell gather in one mass, the cell wall splits near one end, and the mass, with a small colorless protuberance on one end surrounded by numerous cilia, escapes and swims away to form a new plant.

\section{Key to Genera.}

Cells long, without a laterally placed bristle. Edogonium* Cells short, with a laterally placed bristle....Bulbochate* 


\section{Description of Genera.}

Edogonium Lk.-Filaments simple, articulate; the end cell sometimes setiform, sometimes with an acute conical cap; cells enlarged at the upper extremities. The ooggonia and antheridia-are either on the same or on different filaments. Dwarf males, shaped like inverted flasks, are parasitically situated near the oögonium. The elongated males are independent and shorter than the female plant. When a cell has reached maturity, it splits below the top by a circular line, the top is raised by growth, and a new cell formed. This may split again, and a new growth push the top up and leave another ring; this may be repeated five or six more times, leaving a new ring each time.

O. sp. (?), Fig. 96.

O. cardiacum (Hass.) Wittr. (?), Fig. 228. Male and female specimens.

[O. crenulato-costatum Wittr.]

Bulbochæte Ag.-Filaments much branched; almost all the cells thickened upwards, and bearing on that end long, thin, transparent bristles, bulbose at the base. Reproduction as in Edogonium. The plants are more often mixed than in Edogonium, and are enveloped in a quantity of mucus.

B. sp. (?), Figs. 97, 98.

[B. intermedia DeBary.]

\section{ORDER VI. CLADOPHORALES.}

Three families, very like the Siphonales, comprise this order. The thallus is simple or branched, incompletely divided into cells. Each portion contains many nuclei and parietal chloroplasts, with single pyrenoids. Asexual reproduction by resting spores, cysts, or zoögonidia with two or four cilia. Sexual reproduction by heterogamous or isogamous gametes.

The order is divided into families, as follows:-

\section{Key to Families.}

I. Filaments unbranched, compound or elongated cœno-

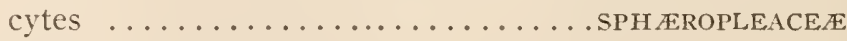
Filaments branched................. 2 
2. Producing barrel-shaped and fusiform resting spores

PITHOPHORACEX

Without the barrel-shaped resting spores........

CLADOPHORACE压

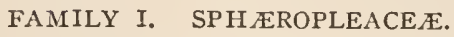

The thallus is unbranched, composed of cells from one to ninety times as long as wide, each with several nuclei, and parietal chloroplasts in the form of rings. Any segment of the filament may form an oögonium or a bright red antheridium. These sometimes alternate in a filament. Many antherozoids are formed on the breaking up of the antheridium, and they penetrate the oögonium through the transverse walls. Bright red oöspores with thick walls are produced, which hibernate in the oögonium, and on germination from two to eight zoöspores are set free, which produce young plants, simple, fusiform, attenuated to a fine point on each end.

Sphæroplea Ag.-Coextensive with the family. Its filaments are 36-62 microns in diameter.

FAMILY II. PITHOPHORACE E.

Thallus much branched, segments six to twelve or more times longer than broad. Usually many nuclei in a segment, chloroplast parietal; growth apical; attached below by a rhizoid. Asexual, green resting spores with thick walls are produced here and there; when intercalated, cask-shaped; when terminal, ovoid or fusiform. They develop on germination at both ends.

Pithophora Wittr.-Coextensive with the family. It is almost exclusively tropical.

\section{FAMILY III. CLADOPHORACEÆ.}

Thallus large, filamentous, incompletely septate, branched in Cladophora. Each segment contains several nuclei and one reticulated parietal chloroplast or several smaller ones, each with a pyrenoid. In Cladophora and Chatomorpha asexual reproduction is by zoögonidia, formed in great numbers in the mother-cell. Rhizoclonium produces thick-walled cysts. Cladophora has also an isogamous sexual reproduction. 
The Cladophoracea secrete very little or no mucus, and are, therefore, a resting place for epiphytes.

\section{Key to Genera.}

I. Filaments unbranclied; cells often slightly swollen

Chatomorpha

Filaments commonly branched; cells not swollen... 2 2. With branched rhizoids ............Rhizoclonium* Without rhizoids .......................

Description of Genera.

Chætomorpha Kütz.-Wide, simple filaments of thickwalled, swollen segments; fixed at the base, the basal segments being shorter than the rest. The cell wall is firm and lamellose. Mostly marine or in brackish water.

Rhizoclonium Kütz.-Filaments slightly branched, with branched rhizoids at the base; articulate, somewhat contorted, having here and there short branches composed of from one to three cells.

[R. lacustre forma Americanum Wille; R. hieroglyphicum var. macromeres Nordst.]

Cladophora Kütz.-Filaments much branched, the last branches much thinner than the main stem; cell walls thick, cells longer than broad. Propagation by zoögonidia, which develop in large numbers within the cells.

C. glomerata (L.) Kütz., Fig. 274 .

[C. callicoma Kütz.]

\section{ORDER VII. SIPHONALES.}

Plant composed of an elongated cœnoçytic filament (canocyte), which is much branched. The order inhabits salt water almost exclusively. The only family living in fresh water is the Vaucheriacea.

\section{FAMILY I. VAUCHERIACE五.}

Thallus elongated, somewhat branched, cœnocytic, usually attached. The protoplasm contains many minute nuclei. The oval chloroplasts are small and numerous. The cell wall is thin and easily broken; after which the injured part is cut off by a septum, and the uninjured parts develop into new plants. 
Vaucheria D. C.- Many filaments growing from one root, green, rather stout. A single filament usually more or less branched, with chlorophyll quite evenly distributed on the inside of the cell wall, forms one plant. Sexual reproduction by oöspheres and spermatozoids; asexual reproduction by zoöspores. One zoöspore, provided with many cilia, is formed in a swelling at the tip of the thallus, cut off from the rest of the cell by a wall. The oögonia and antheridia, either sessile or on short pedicles, grow in various numbers on the same tube and usually close together.

. V. sessilis (Vauch.) D. C., Figs. 200, 20I. Sexual organs of this species are shown in Fig. 206.

[V. aversa Hass.; $V$. geminata (Vauch.) D. C.]

\section{ORDER VIII. CONJUGATE.*}

The Conjugate are green or brownish Algæ, sometimes single-celled, but usually composed of many cells closely joined. They are named from the peculiar mode of propagation. Two cells unite their entire contents to form a zygospore; rarely two zygospores result from such a union. Resting spores or cysts are produced in the Zygnemacea without copulation. Non-motile spores are sometimes formed. All the Conjugate are very slimy to the touch.

\section{Key to Families.}

Unicellular; cells commonly constructed of two symmetrical halves; of very many forms, though rarely cylindrical; single, or, very rarely, bound together in a loose thread; two to eight germs develop from a single zygospore......... DESMIDIACE. E Thallus a thread of many similar cells; each zygospore produces only one germ plant..... ZYGNEMACE\&

* Our work upon the remaining orders of Chlorophycex is as yet quite in. complete. These Algæ are abundant in our waters. In the filamentous forms it is difficult or impossible to identify the species from the vegetative stages; and, since in ordinary waters it is usual to find these stages only, specific determination is frequently impossible. The family of Desmidiacea is very abundant; and, while our list contains a large number of them, doubtless a longer study will show many more species. The common species are, however, fairly well represented. 


\section{FAMILY I. DESMIDIACEX.}

Cells of various forms, but symmetrical, single, or, in a few genera, loosely united into threads. Often a constriction in the middle of the cell divides it into halves, called semi-cells; the cell contents nearly always divided. The cell wall is often provided with granules, spines, or other protuberances, which are usually arranged in a definite pattern. These projections serve as a protection from aquatic animals, and as an anchor in times of flood. Conjugation of two cells results in zygospores. Asexual multiplication by transverse division or separation of semi-cells. The Desmidiacea are surrounded by a mucus exuded through pores in the cell wall, and often may be found embedded in a mass of jelly.

They are not free-swimming, but are able under certain conditions of light and gravitation to glide along a hard surface.

Desmids are extremely abundant the world over; there are several thousand known species, living in all degrees of temperature, and found most abundantly in soft water.

The following key, modified from West, includes all the known genera of Desmids, four of which (Ichthyocercus, Triploceras, Phymatodocis, and Streptonema) are exclusively tropical, and one (Ancylonema) is exclusively arctic. We have identified certainly as yet only a part of the Connecticut species, but have indicated by an asterisk the genera, and have figured the species thus far observed.

\section{Key to Sub-families.}

Cell wall not evidently divided into two parts, and

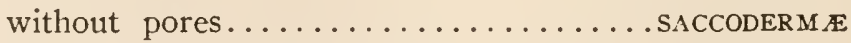

Cell wall showing two segments, and with a differentiated outer porous layer........... PLACODERM $\mathbb{E}$

\section{SUB-FAMILY I. SACCODERM}

Cell wall unsegmented and without pores. Point of division of cells indefinite, and unknown previous to the actual division. The young half of the cell is developed obliquely, and its walls are absolutely continuous with the walls of the older half. 


\section{Key to Tribes and Genera.}

Tribe I. gonatozygex. Cells elongate, cylindrical, and unconstricted, forming loose filaments. Cell wall with a differentiated outer layer, of which the small roughnesses and spines form a part.

Chloroplasts axile..................Gonatozygon

Chloroplasts parietal and spirally twisted....Genicularia

TRIBE. II. SPIRoT ENIEA. Cells solitary, relatively short, and mostly unconstricted. Cell wall a simple sac, without a differentiated outer layer. The cell becomes adult by periodical growth.

I. One chloroplast in each cell................ 2

Two chloroplasts in each cell................ 4

2. Chloroplast spirally twisted, axile or parietal. .Spirotcnia Chloroplast plane, axile.................. 3

3. Cells solitary.......................esotanium* Cells forming short filaments............Ancylonema

4. Chloroplasts star-shaped, radiating from a central

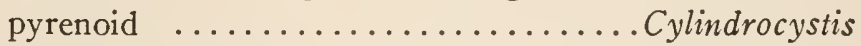

Chloroplasts ridged with longitudinal serrated ridges

Netrium*

\section{Description of Genera.}

Gonatozygon D. By.-Cells long and straight, not constricted, forming filaments which break up at maturity. The cell wall is smooth or covered with minute granules. The two chloroplasts are axile, thin and waving or twisted; they contain four to sixteen equidistant pyrenoids. The zygospores, which quickly separate from the empty cells, are smooth.

Spirotænia Breb.-Cells straight, fusiform, ends rounded, not constricted in the middle; cells single or several, covered by a gelatinous envelope. Chloroplasts spiral bands on the inside of the cell wall.

Mesotænium Näg.-Cylindrical cells, straight or slightly curved, without median constriction. The ends are broadly rounded. The chloroplast is a flat plate, extending from one end of the cell to the other; occasionally there are two chloroplasts.

M. micrococcum (Kütz.) Roy and Biss., Fig. 219. 
Netrium Näg.-Cylindrical, straight, or fusiform cells, without constriction. Chloroplasts two (or four) in each cell, each with longitudinal serrate ridges.

N. interruptum (Breb.) Lutkem, Fig. 281.

N. Digitus (Ehrb.) Itz. and Roth., Fig. 282.

SUB-FAMILY II. PLACODERM E.

Cell wall mostly constricted, with a differentiated outer layer. Cell division follows a fixed type, with interpolation of the younger halves between the old ones. The younger portions of the cell wall are joined to the older portions by an oblique surface.

\section{Key to Genera.}

I. After division the cells remain free and solitary.... 2 After division the cells remain attached to form colonies ...................... I4

2. Cells more or less constricted at the middle...... 5

Cells not constricted................. 3

3. Cells of moderate length, straight, cylindrical...Penium* Cells elongate, generally curved and attenuated.... 4

4. Cells almost cylindrical, scarcely attenuated; chloroplast single, without apical moving granules... Roya* Cells strongly attenuated towards each extremity; two chloroplasts in each cell, with apical moving granules ..........................

5. Cells elongated and cylindrical, constriction slight. . 6 Cells relatively short; deeply constricted........ Io

6. Apices of cells truncate or rounded, entire...... 7 Apices of cells cleft, incision open or narrow..... 8

7. Base of semi-cells plicate.............. Docidium* Base of semi-cells plane.............Pleurotanium*

8. Cell wall adorned with rings of furcate processes..

Triploceras

Cell wall plane ....................... 9

9. Apical incision widely open, each apical angle furnished with a spine.............. Ichthyocercus Apical incision narrow............... Tetmemorus

Io. Cells compressed (at right angles to the plane of the 
front view), in the vertical view fusiform or el-

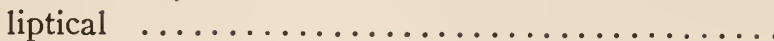

Cells in vertical view radiating, triangular, quadrangular, or radiate; rarely fusiform...... Stcurrastrum*

I I. Cells mostly oblong or elliptical; moderately lobed; margins wavy, the depressions rounded....Euastrum* Cells very much compressed, mostly orbicular or broadly elliptical, deeply lobed or incised.Micrasterias* Cells with a more or less entire margin, often furnished with warts or spines..............

12. Cell wall with regularly arranged spines of considerable length ...................... I3

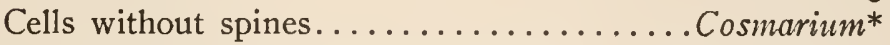

13. Spines several, commonly in pairs; a central protuberance always present.............Xanthidium*

Spines 4 or 8 , occasionally 16 , no central protuberance Arthrodesmus*

14. Colonies spheroidal; cells not in contact, but joined

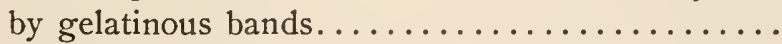

Colonies thread-like; cells attached by their apices to form long filaments.................. 16

I5. Gelatinous bands narrow; few cells forming a microscopic colony.................. Cosmocladium

Gelatinous bands very broad, many cells forming a macroscopic colony............... Oöcardium

16. The line of division of the cell, where the new and old parts of the cell wall are obliquely fitted to gether, develops a girdle during division.........

The line of division does not develop a girdle during division ........................ I7

I7. Cells attached by special apical processes....... I8 Apices of cells plane and flat............. I9

18. Apical processes very short............Spharozosma* Apical processes long and overlapping the apices of the adjoining cells ............. Onychonema*

19. Cells deeply constricted................. 20 Cells slightly constricted..............Hyalotheca*

20. Cells in vertical view elliptical......... Spondylosium* Cells in vertical view quadrangular with produced angles Phymatodocis 
21. Cells joined by special apical processes..... Streptonema Cells joined by their flat apices or by flattened apical projections ................... 22

22. Cells short, in vertical view fusiform, triangular, or quadrangular (rarely circular with produced angles) $\ldots \ldots \ldots \ldots \ldots \ldots \ldots$ Desmidium*

Cells elongate, cylindrical............. Gymnozyga

\section{Description of Genera.}

Penium Breb.-Cells straight, cylindrical or fusiform, without mediar constriction, ends rounded; free or collected in a gelatinous membrane. Cell wall smooth, or minutely granular, colorless or sometimes red, often finely striate. Chloroplast axile; when seen in cross section star-shaped, with arms often forking. Multiplication by division, and by zygospores formed by conjugation.

$P$. closterioides Ralfs, Fig. I72.

P. polymorphum Perty, Fig. I73.

P. margaritaceum (Ehrb.) Breb., Fig. I75.

P. Navicula Breb., Fig. 218.

Roya West.-Cells curved but not attenuated. Cell wall without pores, chloroplast single, without dancing granules.

R. obtusa (Breb.) West, Fig. I45.

Closterium Nitzsch.- Cells simple, elongated, crescentshaped or lunately curved, entire. The centres are not constricted, but often bear a few transverse striæ. The cell walls are smooth or finely striate, colorless or brown; at each end of the cell is a vesicle, colorless or straw-colored, containing numerous granules. The chloroplasts are arranged in longitudinal rows broken in the middle by a transverse, colorless band.

C. acuminatum Kütz., Fig. I47.

C. lanceolatum Kütz., Fig. I48.

C. Cucumis Ehrb. (?), Fig. I49.

C. acerosum (Schrank) Ehrb. (?), Figs. I50, I5I.

C. Lunula Ehrb., Fig. I 52.

C. turgidum Ehrb., Fig. I53.

C. strigosum Ehrb., Fig. I54.

C. costatum Corda, Fig. I 55 .

C. Delpontei Klebs, Fig. 156. 
C. prelongum (Breb.) Delp., Fig. I57.

C. lineatum Ehrb., Figs. I57a, I58.

C. decorum Breb., Fig. 159.

C. areolatum Wood, Fig. I6r.

C. Diance Elirb., Fig. I62.

C. Jenneri Ralfs, Fig. I6o.

C. parvulum Näg., Figs. 163,164 .

C. moniliferum (Bory) Ehrb., Fig. I65.

C. Leibleinii Kütz., Fig. I66.

C. Leibleinii var. curtum West, Fig. I67.

C. rostratum Ehrb., Fig. 168 .

C. rostratum var. brevirostratum West, Fig. I69.

C. subcostatum Nord., Fig. I7o.

C. Brébissonii Delp., Fig. I7 I.

Docidium Breb.-Cells straight, cylindrical or fusiform; ends rounded, truncate or smooth, constricted in the middle; each semi-cell furnished with a basal inflation. The base is plicate with a granule under each plication. Chlorophyll axile and an axile row of pyrenoids. The ends have a vacuole containing dancing granules.

D. Baculum (Breb.), Figs. I03, 223.

D. verticillatum (Bailey) Ralfs, found but not figured.

Pleurotænium Näg.- In shape much like Docidium, without plications at the base of the semi-cells. The ends are truncate and usually furnished with a ring of tooth-like projections. The parietal chloroplasts are longitudinal and are provided with several pyrenoids. The centre of the cells usually contains large vacuoles, and in the apical ones moving granules are often seen.

P. crenulatum (Ehrb.) Rab., Fig. 224.

P. Archerii Delp., Fig. 225.

P. Trabecula (Elırb.) Näg., Fig. 226.

P. nodosum (Bail.) Lund., Fig. 283.

P. sp. (?), Fig. гог.

Tetmemorus Ralfs.-Cells like Penilum, except that the ends are slightly cut and the middle is constricted. One central chloroplast with a single row of pyrenoids is present. Cell wall mostly punctate or granulose. 
Staurastrum Meyen.-The second largest genus of Desmids. Cells in front view oblong, cylindrical, elliptical, or orbicular, with margins notched or smooth, always constricted in the middle, ends rounded, entire. End view with three to six obtuse, acute, or horn-like angles. Chlorophyll more or less central, zygospores commonly furnished with spines (see Fig. 26I).

S. orbiculare (Ehrb.) Ralfs, Figs. 123, 124.

S. dejectum (Breb.) var. convergens Wolle, Fig. I22.

S. dejectum var. mucronatum Ralfs, Fig. I25.

S. megacanthum Lund., Figs. 126, 127.

S. hirsutum (Ehrb.) Breb., Figs. 133, 263, $263 a$.

S. brevispinum Breb., Fig. I28.

S. leptocladum Nord., Figs. 264, $264 a$.

S. erasum Breb., Figs. I30, I3I.

S. arctiscon Ehrb., Figs. 268, 268a.

S. odonatum Wolle, Fig. I32.

S. coronulatum Wolle, Figs. $267,267 a$.

S. Ravenelii Wood, Figs. I34, I35.

S. dejectum Breb., Figs. 233, 236.

S. furcigerum Breb., Fig. 136.

S. crenulatum (Delp.) Näg., Fig. 23I.

S. margaritaceum Ehrb., Fig. 235 .

S. iotanum Wolle, Fig. I43.

S. eustephanum Ralfs, Fig. I44.

S. pygmaum Breb., Fig. 261. Conjugating.

S. muricatum Breb., Fig. I29.

Four'species, names unknown, Figs. I37-I42.

$S$. gracile Ralfs, found but not figured.

Euastrum Ehrb.-Cells elliptical or oblong, deeply constricted; semi-cells usually cut at the ends and wavy or lobed at the sides, the number of lobes being uneven; usually furnished with circular inflated protuberances.

E. integrum Wolle, Fig. I05.

E. verrucosum (Ehrb.) Ralfs, Fig. I04.

E. oblongatum (Grev.) Ralfs, Fig. 229.

E. ampullaceum Ralfs, Fig. 230.

E. elegans Kütz., Fig. $23^{2}$.

E. Nordstedtianum Wolle, Fig. 234. 
E. sp. (?), Fig. 227.

E. ansatum (Ehrb.) Ralfs, found but not figured.

Micrasterias Ag. (Holocystis Hass.; Tetrachastrum Dixon).- Cells simple, flattened, in the form of a double-convex lens, deeply constricted in the middle. Front view orbicular or broadly elliptical; end view spindle-shaped, with acute ends. Each semi-cell three- to five-lobed; lateral lobes entire, or irregularly cut into large, deep lobes; the end lobes entire, or more slightly cut, sometimes with angles pronounced, and two-cleft. Zygospores seldom found, large, globular, with stout spines which are at first simple and later branched.

M. radiosa (Ag.) Ralfs var. punctata West, Fig. 106.

M. apiculata Menegh., Fig. 108.

M. rotata (Grev.) Ralfs, Fig. 238.

M. furcata (Ag.) Ralfs, Fig. 239.

M. Americana (Ehrb.) Kütz., Fig. 240.

M. muricata Bailey, Fig. $24 \mathrm{I}$.

M. truncata (Corda) Ralfs, Fig. 242.

M. Crux-Melitensis (Ehrb.) Hass., Fig. 107.

Arthrodesmus Ehrb.-Cells simple, deeply constricted in the middle; each half-cell is wider than long, and furnished with several spines. This genus is distinct from Xanthidium by the absence of the protruding area in the centre of the semicells. There are usually fewer spines, and the zygospores are either smooth or spinous.

A. octocornis Ehrb., Fig. 260.

A. convergens (Ehrb.) Ralfs, Fig. 259.

Cosmarium Corda (Dysphinctium Näg.; Calocylindrus (Näg.) Kirch.; Cosmaridium Gay; Pleurotæniopsis (Lund.) Lagerh.).- The largest genus of Desmids. The single cells circular, elliptical, or oblong, usually one and onehalf diameters in length, always more or less constricted in the middle. Ends usually entire, rounded or truncate. The margins are smooth, dentate, or crenate, the cell wall smooth, punctate, warty, or even covered with spines. End view oblong or oval, with sometimes a swelling in the middle of the longer sides. Zygospores usually spherical, sometimes cubical or angular, smooth or furnished with spines. 
C. Botrytis Menegh., Figs. II5, II6.

C. Broomei Thwaites, Figs. 99, 258.

C. suborbiculare Wood, Fig. 113 .

C. granatum Breb., Fig. Io9.

C. crenatum Ralfs, Fig. IIo.

C. contractum Kirch., Fig. II7.

C. tumidum Lund., Figs. 100, rooa.

C. ornatum Ralfs, Fig. IO2.

C. ovale Ralfs, Fig. 245.

C. undulatum Corda, Fig. 244 .

C. pyramidatum Breb., Fig. 246.

C. Meneghinii Breb., Fig. 247.

C. octhodes Nord., Fig. 248.

C. perforatum Lund., Fig. 249.

C. Nägelianum Breb., Fig. 250.

C. intermedium Delp., Fig. $25 \mathrm{r}$.

C. Portianum Arch., Fig. 252.

C. orbiculatum Ralfs, Fig. 253.

C. tetrophthalmum (Kütz.) Breb., Fig. 254.

C. galeritum Nord., Fig. 255 .

C. Cucurbita Breb., Fig. 256.

C. pseudobroomei Wolle, Fig. 257.

Xanthidium Ehrb.-Cells single, or two joined end to end; deeply constricted; semi-cells wider than long, entire, furnished with spines, and with a round, truncate, or toothed arm projecting from the centre. The spines are either simple or with two or three forks at the end. In the centre of each semi-cell is a roughened protruding area of variable size. Zygospores spherical and spinous.

X. fasciculatum (Ehrb.) Ralfs var. subalpinum Wolle, Figs. I2r, 266.

X. antilopæum (Breb.) Kütz., Fig. 262.

X. cristatum (Breb.) Ralfs, Fig. 265.

$X$. aseptum Nord., found but not figured.

Sphærozosma Corda.- Filaments of cells closely united by a narrow isthmus or by a granular process. Cells deeply constricted, thus forming bilobed cells.

S. fliforme Rab., Figs. II8, Ir9. 
S. spinosum Delp., Figs. I20, 277.

S. pulcrum Bailey, Fig. $27 \mathrm{I}$.

Onchonema Wall-Like Spharozosma except that the granular processes are long.

O. serratum (Bailey) Wall., Fig. 272.

Hyalotheca Ehrb.-Cells short, cylindrical, usually blunted, constricted in the centre; joined in long filaments enclosed in an ample mucilaginous sheath. The end view of the cell is round and shows the chloroplast to be eight- to ten-rayed.

H. dissilicns (Sm.) Breb., Fig. 273.

Spondylosium Breb. (Leuronema Wallich).-Like Spharozosma except that instead of being united by lateral processes, the cells are joined in filaments merely by the close apposition of the cells.

S. papillatum West, found but not figured.

Desmidium Ag. (Didymoprium Kütz.; Aptogonum Ralfs).-Cells incised or entire, with two chloroplasts barely touching in the middle; triangular or quadrangular in end view; united into fragile, elongated filaments, regularly twisted, and enclosed in a mucous envelope.

D. cylindricum Grev., Fig. 276 .

D. Swartzii Ag., Fig. 275.

Gymnozyga Ehrb. (Bambusina Kütz.).-Cells barrelshaped with one or more narrow bands around the middle; closely united into articulate filaments. Chlorophyll bodies as in Hyalotheca. Zygospores smooth, ellipsoidal.

\section{FAMILY II. ZYGNEMACEIE.}

Unbranched filaments composed of single cells or of a simple series of cells. Chloroplasts in the shape of spiral bands, axile plates, or twin stellate bodies.

Key to Sub-families.

Conjugation producing a zygospore which, after a period of rest, develops directly into a new gameto-

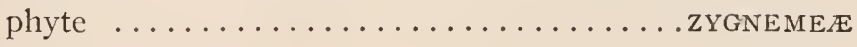


Conjugation producing a zygospore which immediately develops a sporocarp of several cells, one of which is the spore. The gametophyte is developed from this spore after a period of rest.... MESOCARPE $E$

\section{SUB-FAMILY I. ZYGNEME尺.}

Filaments unbranched. A lining of protoplasm is in each cell, and the nucleus is held in the centre by quite prominent bands of protoplasm. The chloroplasts containing numerous prominent pyrenoids are twin stellate bodies in Zygnema and spiral bands in Spirogyra.

Vegetative multiplication by breaking of filaments into separate cells or groups of cells. Asexual reproduction by spores. Sexual reproduction by conjugation between cells of different filaments which lie close together. Each cell puts out a tube on the side nearest the other filament, and these meet with similar tubes from the cells of the other filament. The ends of the tubes join, and an open "conjugating tube" is formed. The contents of the cells separate from the cell walls, and the mass from one cell flows into the other, there to unite with the mass in that cell and form a zygospore. The zygospores are usually all found in one of the two filaments. Occasionally lateral conjugation between two cells of the same filament is observed.

\section{Key to Genera.}

Cells containing two star-shaped chlorophyll bodies near the nucleus.......................

Cells with spirally twisted bands of chlorophyll...

Spirogyra*

Cells with nearly straight bands of chlorophyll.Choaspis*

\section{Description of Genera.}

Zygnema Ag. (Zygogonium Kütz.).-Cells with two star-shaped chlorophyll bodies near the nucleus, each chloroplast bearing a starch grain.

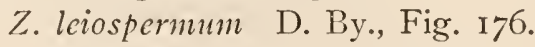

Z. stcllium Ag., Figs. I77, I78.

Z. stellium var. genuinum Kirch., Fig. I79. 
Z. pectinatum (Vauch.) Ag., Fig. 279. In conjugation.

Z. cruciatum (Vauch.) Ag., Fig. I8o.

Spirogyra Link.-Cells with from one to many bands of chlorophyll in the cell wall, winding to the right. The zygospores are always inside the walls of one of the conjugating cells.

The length and width of the cells, the form of the dividing wall (which may be plane or replicate, $i$. $e$., with an annular ingrowth of cellulose), the number of spirals, and the number of turns each spiral makes in a cell, are all points for consideration; but the zygospores form the only decisive factor in the determination of species. In the determination of the species given below, we have chiefly relied on the vegetative thread.

Found in low-lying ponds and ditches.

S. varians (Hass.) Kütz., Figs. I81, I82.

S. Weberi Kütz., Figs. I83, I84.

S. matrima (Hass.) Witt., Fig. I85.

S. jugalis (Dillw.) Kütz., Figs. I86, 187.

S. inflata (Vauch.) Rab., Fig. 269.

S. calospora Cleve, Fig. I95.

S. dubia Kütz., Fig. I88.

S. quimina (Ag.) Kütz., Figs. I89, I90.

S. Grevilleana (Hass.) Kütz., Fig. I9I.

S. majuscula Kütz., Fig. I92.

S. adnata Kütz., Fig. I93.

S. Spreciana Rab., Fig. I94.

S. decimina (Müll.) Kütz., Fig. Ig6.

S. communis (Hass.) Kütz., Fig. I97.

S. fuviatilis Hilse, Figs. I98, I99.

S. mirabilis Hass., Fig. 202.

S. bellis (Hass.) Cleve, Figs. 203, 204, 270.

S. Alavescens (Hass.) Cleve, Fig. 205.

S. crassa Kütz., Fig. 6o.

[S. nitida (Dillw.) Link.]

Choaspis S. F. Gray (Sirogonium Kütz.).- Filamentous. The only genus of Conjugatæ without a mucous coat. Sterile cells much like Spirogyra; conjugating cells arise by unequal division of the cells of the filaments, and, 
bending knee-like towards each other, grow together; zygospores elliptical.

\section{- SUb-FAMily iI. MESOCARPEA.}

The plants of this sub-family are often narrower than those of Zygnemex, with thin cell walls. The chloroplast is a thin axile plate, and all those of a filament usually lie in one plane. The chloroplasts change their position according to the degree of light, turning the edge to bright light and the face to dim light. Reproduction as in Zygnemex.

Key to Genera.

Plants reproducing by conjugation..........Mougeotia* Reproduction by non-sexual methods only. Gonatonema

\section{Description of Genera.}

Mougeotia A. Br. (Staurospermum Kütz.; Mesocarpus Hass.; Craterospermum Braun; Plagiospermum Cleve).Cells long, cylindrical, with axile chloroplasts. Conjugation scalariform; zygospores spherical or quadrate and more or less flattened with rounded angles.

M. sp. (?), Fig. 85. The method of conjugating is shown in Fig. 280. Ag.]

[M. robusta (De Bary) Wittr.; M. genuflexa (Dillw.)

Gonatonema Wittr.-Cells similar to Mougeotia, but reproduction only by means of non-sexual spores. Spores produced without conjugation, formed by division of the mothercells, which are afterwards often burst and bent angularly and alternately at the point of fructification.

\section{CLASS V. CHARACE}

Algæ with a peculiar odor; often encrusted with lime. Thallus a stem with nodes and internodes. The plants grow from a few inches to over a foot in height by means of an apical cell. Whorls of leaves, on which may be borne antheridia and oögonia, grow at the nodes.

Zoöspores are wanting. The organs of reproduction are conspicuous in color and form. The antheridia are spherical, 
red when mature, the wall consisting of eight shields or plates. The spermatozoids are spirally coiled. The oögonium is situated on a nodal cell from which five other cells grow and coil around the oögonium, covering it closely. They divide once or twice at the top, so that a crown of five or ten small cells is formed.

\section{Description of Genera.}

Chara Vaill.- The crown consists of five cells. The stems are covered with a cortex.

C. $s p$. (?), Figs. 207-209.

Nitella Ag.- The crown consists of ten cells; cortex lacking.

\section{CLASS VI. PHÆOPHYCEÆ (FUCOIDE}

The Algæ of this class are almost exclusively salt-water forms, known as the Brown Seaweeds, and include the most highly developed of the Seaweeds. The vegetative cells are uninucleate, and the chromatophores are distinctly brown.

Asexual reproduction by means of motile cells or zoögonidia. Sexual reproduction by isogamous or heterogamous gametes. Copulation always takes place outside the plant, and the resulting spore germinates directly. The motile cells always possess two laterally placed cilia, one directly forward and the other backward.

While the class is made up mostly of marine plants, there is one order that is found in fresh water.

\section{ORDER I. SYNGENETICA.}

Exclusively fresh-water forms. Plants unicellular, solitary or colonial, or multicellular; free-swiming or motionless. The cells are either naked or surrounded by a mucilaginous envelope. The cells are uninucleate, posseșs one or more pulsating vacuoles, one or two yellow or pale brown chromatophores, and occasionally pyrenoids.

The order as thus defined includes about seven families. But at least four of the seven are frequently classed with the Flagellate Protozoa, and are described in the report upon the Protozoa of our waters. These include the following genera: 
Cryptomonas, Synura, Uroglena, Dinobryon. (See Bull. No. 2 of this Survey.)

The only other family known to us to occur in our fresh water is the following:-

\section{FAMILY I. HYDRURACEA.}

The plant consists of an attached colony, from two to twelve inches long. The cells have each one chromatophore, lack a cell wall, and are embedded in a large mass of jelly. Cells brown at one end, colorless at the other; arranged in irregular, longitudinal families; at first globose, then elliptical. Division at first in one, later in two directions.

Asexual reproduction by uniciliated tetrahedral zoögonidia. Two or four of them are produced from each cell of the branches, and germinate at once. Resting spores have been observed.

Hydrurus Ag.-Coextensive with the family.

\section{CLASS VII. RHODOPHYCE E (FLORIDE $A$ ).}

Plants generally rosy red or purple, dark reddish-brown, or blackish. Most closely related to salt-water Algæ. Crustaceous, filamentous, variously branched.

Asexual propagation by means of motionless spores. In the sexual reproduction, which is wanting in some of the genera, the female cell, called the carpogonium, is fertilized by a mass of protoplasm, called spermatium, derived from a male cell. The result of fertilization is called a cystocarp, and the method of its formation determines the different groups of Rhodophyceæ.

Sometimes the cystocarp is developed directly, and sometimes the fertilized carpogonium puts out growths, known as oöblastema-filaments, which conjugate with auxiliary cells, the result being the cystocarp. The carpospores are always developed on a tuft of filaments which spring from the fertilized cells and are called gonimoblasts.

Of the four orders of this class, two are found in fresh water. They are distinguished as follows: 
Key to Orders.

Carpogonium developing directly...... NEMALIONALES Carpogonium developing a filament of which two cells conjugate with each other.... CRYPTONEMIALES

\section{ORDER I. CRYPTONEMIALES.}

A long branched filament is sent out from the fertilized carpogonium. Each terminal cell of the filament unites with an auxiliary cell, and from the latter the gonimoblasts arise.

\section{FAMILY I. SQUAMARIACEE.}

A small group, mostly marine, but with a few fresh-water species. The thallus consists of dense, upright cell-filaments, which form minute, flat, gelatinous or membranous expanses. Cavities in the upper surface of the thallus hold the sexual organs, and, after the fertilization of the carpogonia, are filled with cystocarps.

Hildenbrandtia Nardo.- Thallus crustaceous; firmly adhering, formed of subcubical, blood-red, dark red, rose, or brown cells, placed in close vertical series. Sexual organs in cavities in the upper surface.

\section{ORDER II. NEMALIONALES.}

The gonimoblasts are developed in tufts, directly from the fertilized carpogonium.

\section{Key to Families.}

Thallus with a basal attached portion, from which arise tufts of simple or branched filaments....

LEMANEACEA

Thallus filamentous, simple or branched, with secondary axes often in whorls... HELMINTHOCLADIACE $E$

\section{FAMILY I. LEMANEACE E.}

Exclusively fresh-water Algæ, growing in very rapid water. The thallus consists of a basal attached portion from which arise dense tufts of erect branched filaments. From these grow the fructiferous branches which are the most conspicuous part of the plant. After the growth of this part, the 
vegetative portion of the thallus generally dies away, and these branches become fixed by rhizoids of their own. The fructiferous branches are long, filamentous, cartilaginous, and swing freely in the water; they are olive-green or greenish black. Each thread is built up of an axile row of tubular cells surrounded by rows of smaller cells; at short, more or less regular, distances along the entire length are distinct swellings or nodes.

Only sexual multiplication is known. The antheridia are short and cylindrical, growing on whorled eminences or on the widest part of the nodes. The carpogonium possesses a long, simple or branched process for the reception of the male gamete, called a trichogyne. After fertilization the carpogonium puts out an oöblastema-filament, at the extremity of which a bunch of jointed moniliform filaments arises, each of the swollen cells of which becomes at maturity a carpospore. The carpospores are produced on the inside of the thallus, filling up the space between the axile cells and the cortical cells. The carpospores in turn produce the vegetative thallus.

Lemanea Bory.- Large, simple or somewhat branched, bristle-like threads of dark or brownish color; hollow except for the axile series of cells which is held in place by transverse threads at regular intervals.

[L. fucina var. rigida (Sirdt.) Atk.]

Tuomeya Harvey.- Thallus much branched, upright, five $\mathrm{cm}$. high, rosette-like.

[T. Alviatilis Harvey.]

FAMILY II. HELMINTHOCLADIACEE.

The plants consist of a filamentous thallus, simple or branched, with the secondary axes often arranged in whorls. The main filament may consist of a single row of cells or of an axile row surrounded by cortical rows of smaller cells.

The terminal cells of the gonimoblasts, which are short tufts of filaments, generally form the carpospores. When the carpospore has become detached, the supporting cell grows through the old cell wall and produces a new spore-forming cell. The cystocarp has no definite wall. 
Key to Genera.

I. With clustered tufts of branches....Batrachospermum*

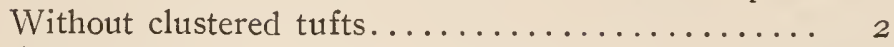

2. Thallus three to seven mm. in length....... Chantransia Thallus thirty to sixty $\mathrm{cm}$. in length.......... Thorea

\section{Description of Genera.}

Batrachospermum Roth.-A wholly fresh-water genus. The plants are diœcious, of a violet or bluish green color. Thallus is from sixteen to twenty $\mathrm{cm}$. in length, moniliform, gelatinous, slippery, consisting of an axile series of cells growing by means of a hemispherical apical cell, and an accessory parallel series, covered with clustered tufts of branches which are more or less scattered. The carpogonium grows in a cell at the extremity of a short branch which stands out directly from the main branch; it possesses a short, straight trichogyne, and after fertilization develops a dense mass of exposed carpospores.

B. vagum (Roth) Ag., Fig. 278.

[B. anatinum Sirdt.; B. Boryanum Sirdt.; B. Corbula Sirdt.; B. ectocarpum Sirdt.; B. moniliforme var. typicum, and var. chlorosum Sirdt.; $B$. pyramidale Sirdt.; $B$. virgatum Sirdt.]

Chantransia Fries.-Diœcious, red, steel-blue, or purplish violet, growing in fresh and salt water. Filaments articulate, branched; branches simple or compound; mucilage lacking.

The carpogonium develops, after fertilization, numerous gonimoblasts in small clusters, upwards and on one side. Asexual multiplication by tetraspores developed on ends of cells.

Thorea Bory.- This genus possesses but one species, $T$. ramosissima Bory. The thallus is round, filamentous, much branched, the thickness of a horse hair, of a purple-brown or dark brown color, very mucous, and reaching the length of thirty to sixty $\mathrm{cm}$. The branches are short and compact, slightly attenuated, and the cells are from two to five times longer than their diameter. The cells possess starch-like granules, and the spores are naked and non-motile. 



\section{INDEX.}

Amphithrix, 15.

Ancylonema, 57.

Ankistrodesmus, 34, 35 .

Aphanocapsa, 12, I3.

Aphanochæte, 50.

Aphanothece, I3.

Apiocystis, 30 .

Aplanospores, 39 .

Aptogonum, 65.

Arthrodesmus, 59, 63 .

Arthrosiphon, 22.

Arthrospira, 18, 20.

Autocolonies, 3I.

Autospores, 3I.

Bacillariæ, 9, 24.

Bambusina, 65.

Batrachospermum, 73.

Botrydiaceæ, 24.

Botrydina, 29.

Botrydium, 25.

Botryococcus, 32 .

Bulbochæte, 5I, 52.

Calocylindrus, 63 .

Calothrix, I5, I6.

Camptotrichaceæ, I6.

Chætomorpha, 54.

Chætophora, 46.

Chætophoraceæ, 44, 45.

Chætophorales, 27, 44 .

Chætosphæridiaceæ, 44, 45.

Chætosphæridium, 50.

Chamæsiphoniaceæ, I4.

Chantransia, 73.

Chara, 9, 69.

Characeæ, 9, 68.

Characiaceæ, 28, 39.

Characium, 39.

Chlamydococcus, 43.

Chlamydomonadex, 42 .
Chlamydomonas, 42.

Chlorobotrys, 25, 26.

Chlorococcus, 29, 38 .

Chlorophyceæ, 9, 26.

Chlorosphæra, 33 .

Choaspis, 66, 67.

Chroöcoccacex, II.

Chroöcoccus, I2, I4.

Chroölepus, 45 .

Cladophora, 54 .

Cladophoraceæ, 53.

Clathrocystis, I3.

Closterium, 58, 6 .

Coccogoneæ, II.

Cœlastreæ, 3I, 36.

Cœlastrum, 36.

Colosphærium, I2, I3.

Conobia, 27, 31 .

Coleochata, 5I.

Coleochætaceæ, 44, 50.

Conferva, 25.

Conjugate, 9, 27, 55 .

Cosmaridium, 63 .

Cosmarium, 59, 63 .

Cosmocladium, 59 .

Craterospermum, 68 .

Crucigenia, 36.

Crucigeniex, 3I, 35 .

Cryptonemiales, 7I.

Cthonoblastus, 20.

Cyanophycex, 9, Io.

Cylindrocapsa, 45, 48 .

Cylindrocapsaceæ, 45, 48.

Cylindrocystis, 57 .

Cylindrospermum, 2I.

Cystococcus, 38 .

Dactylococcus, 34 .

Desmidiaceæ, 55, 56.

Desmidium, 60, 65 .

Diatomaceæ, 9, 24. 
Diatomin, 9.

Dicothrix, I5, I6.

Dictyocystis, 32 .

Dictyosphærieæ, 3I.

Dictyosphærium, 3I, 32.

Didymoprium, 65.

Dimorphococcus, 34 .

Docidium, 58, 6r.

Dolichospermum, 2 I.

Draparnaldia, 46, 47.

Dysphinctium, 63 .

Enteromorpha, 43.

Eremosphæra, 33.

Euastrum, 59, 62.

Eudorina, 40, 4 I.

Eudorinella, 4I.

Gametes, 9.

Genicularia, 57.

Glœocapsa, I2, I3, I4.

Glœocystideæ, 28, 29.

Glœocystis, 29.

Glœothece, I2, I3.

Glœotrichia, I4, I5, I6.

Gomphosphæria, I2, I3.

Gonatonema, 68.

Gonatozygon, 57.

Gongrosira, 45 .

Gonium, 40.

Gymnozyga, 60, 65.

Hæmatococcus, 43.

Hapalosiphon, 23.

Hariotina, 36.

Hassallia, 23.

Helminthocladiaceæ, 7I, 72.

Herposteiraceæ, 44, 50.

Herposteiron, 50.

Heterocysts, Io.

Heterokontæ, 9, 24.

Hildenbrandtia, 7 I.

Hormidium, 44.

Hormiscia, 49.

Hormococcus, 49.

Hormogoneæ, IO, II, I4:

Hormogones, Io.

Hyalotheca, 59, 65.
Hydrodictyaceæ, 28, 37 .

Hydrodictyon, 37, 38 .

Hydrurus, 70.

Hyphœothrix, I9, 20.

Ichthyocercus, 58 .

Inactis, 20.

Isactis, I5, I6.

Kirchneriella, 34 .

Leibleinia, I9.

Lemanea, 72.

Lemaneaceæ, 7 I.

Lemmermannia, 36 .

Leptosira, 45, 46.

Leptothrix, I9.

Leuronema, 65 .

Limnactis, I6.

Lyngbya, I8, I9, 20.

Lyngbyeæ, I7, I8.

Mastigonema, I6.

Mastigothrix, I6.

Merismopedia, II, I2.

Mesocarper, 68.

Mesocarpus, 68.

Mesotænium, 57.

Micrasterias, 59, 63 .

Microcoleus, 20.

Microcystis, I2, I3, 22.

Microspora, 49.

Microsporales, 27.

Microthamnion, 46, 47.

Mougeotia, 68.

Myxonema, 46, 47.

Myxophyceæ, 9, 10.

Nemalionales, 7 I.

Nephrocytium, 33.

Netrium, 57, 58.

Nostoc, 2 I.

Nostocaceæ, I7, 20.

Edogoniales, 27, 5I.

Edogonium, 5I, 52.

Onchonema, 59, 65 .

Ö̈cardium, 59.

Ö̈cystideæ, 3I, 33. 
Öcystis, 33 .

Ophiocytium, 25, 26.

Oscillaria, 19.

Oscillatoria, I8, I9, 20.

Oscillatoriaceæ, I0, I7.

Palmella, 30.

Palmellaceæ, 28.

Palmelleæ, 29, 30.

Palmellococcus, 33, 34 .

Palmodactylon, 30 .

Palmodictyon, 29.

Pandorina, 40, 42.

Pediastreæ, 37.

Pediastrum, 37.

Penium, 58, 60.

Petalonema, 22.

Phæophyceæ, 9.

Phormidium, I8, I9.

Phycocyanin, 9.

Phycoerythrin, Io.

Phycophæin, 9.

Phymatodocis, 59.

Phythelieæ, 3I, 36.

Pilinia, 45.

Pithophora, 53.

Placodermæ, 56, 58.

Plagiospermum, 68.

Planogametes, 30.

Plectonema, I8, I9.

Pleurococcaceæ, 28, 38.

Pleurococcus, 38.

Pleurotæniopsis, 63.

Pleurotænium, 58, 61.

Polycystis, I3.

Polyedrium, 32.

Prasiola, 44.

Protococcaceæ, 28, 31.

Protococcales, 27.

Protococcus, 34, 38 .

Pseudocilia, 29.

Pseudocœnobia, 3I.

Pseudopleurococcus, 38.

Psilonemateæ, I4, I7.

Raphidium, 35 .

Rhizoclonium, 54 .
Rhodophyceæ, Iо.

Rivularia, I5, I6.

Rivulariaceæ, I 5 .

Roya, 58, 60.

Saccodermæ, 56 .

Scenodesmus, 34, 35 .

Schizochlamys, 30 .

Schizogoniales, 27, 43.

Schizogonium, 44.

Schizophyceæ, 9.

Schizosiphon, 22.

Schizothrix, 20.

Schoderia, 35 .

Sciadium, 26.

Scytonema, 22, 23.

Scytonemacer, I7, 22.

Selenastreæ, 31, 34.

Selenastrum, 34, 35 .

Selenosphærium, 36.

Sex union, 9.

Siphonales, 27, 54 .

Sirogonium, $6 \%$.

Sirosiphon, 23.

Sorastrum, 36.

Sphærella, 42.

Sphæroplea, 53.

Sphærozosma, 59, 64.

Sphærozyga, 21.

Spirocoleus, 19.

Spirogyra, 66, 67.

Spirotænia, 57.

Spirulina, 18.

Spondylomorum, 40, 4I.

Spondylosium, 59, 65 .

Spores, 8.

Squamariaceæ, 7 r.

Staurastrum, 59, 62 .

Staurogenia, 36 .

Staurospermum, 68.

Stephanosphæra, 40, 4I.

Stichococcus, 49.

Stigeoclonium, 47.

Stigonema, 23.

Stigonemaceæ, I7, 23.

Streptonema, 60.

Swarm spores; 9. 
Symphysiphon, 22.

Symploca, I8, I9.

Synechococcus, II, I2.

Tetmemorus, 58, 6 I.

Tetrachastrum, 63 .

Tetraedrex, 3I, 32.

Tetraedron, 32 .

Tetragonium, 40.

Tetraspora, 29.

Tetrasporeæ, 28, 29.

Thorea, 73 .

Tolvpothrix, 22, 23.

Trentepohlia, 45 .

Trentepohliacer, 44, 45.

Tribonema, 25.

Tribonemaceæ, 24, 25.

Trichormus, 2I.

Trichophoreæ, 14.

Triploceras, 58.

Tuomeya, 72.

Ulothrix, 49 .
Ulotrichacex, 48, 49.

Ulvaceæ, 43.

Ulvales, 27.

Vaucheria, 55.

Vaucheriaceæ, 54.

Vaginarieæ, 17, 20.

Volvocaceæ, 28, 39.

Volvoce:, 39, 40.

Volvox, 40, 4I.

Willea, 36 .

Xanthidium, 59, 64.

Xanthophyll, 9.

Zonotrichia, I6.

Zygnema, 66.

Zygnemacex, 65 .

Zygnemex, 66.

Zygogonium, 66.

Zygote, 9. 





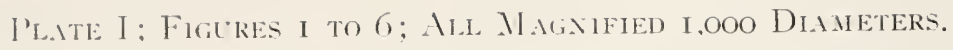

Fig. I. Oscillatoria subtilissima Kütz. . . page 19 Fig. 2. " arugine-corulea Kütz. . “ " " Fị. 3. Merismopedia glanca Näg. . . . " $\quad$ I2 Fig. 4. ". convoluta Iireb. . . .. " Fig. 5. Oscillatoria limosa A. . . . . . . . Fig. 6. . percursa Kütz. . . . . 
Plate I.

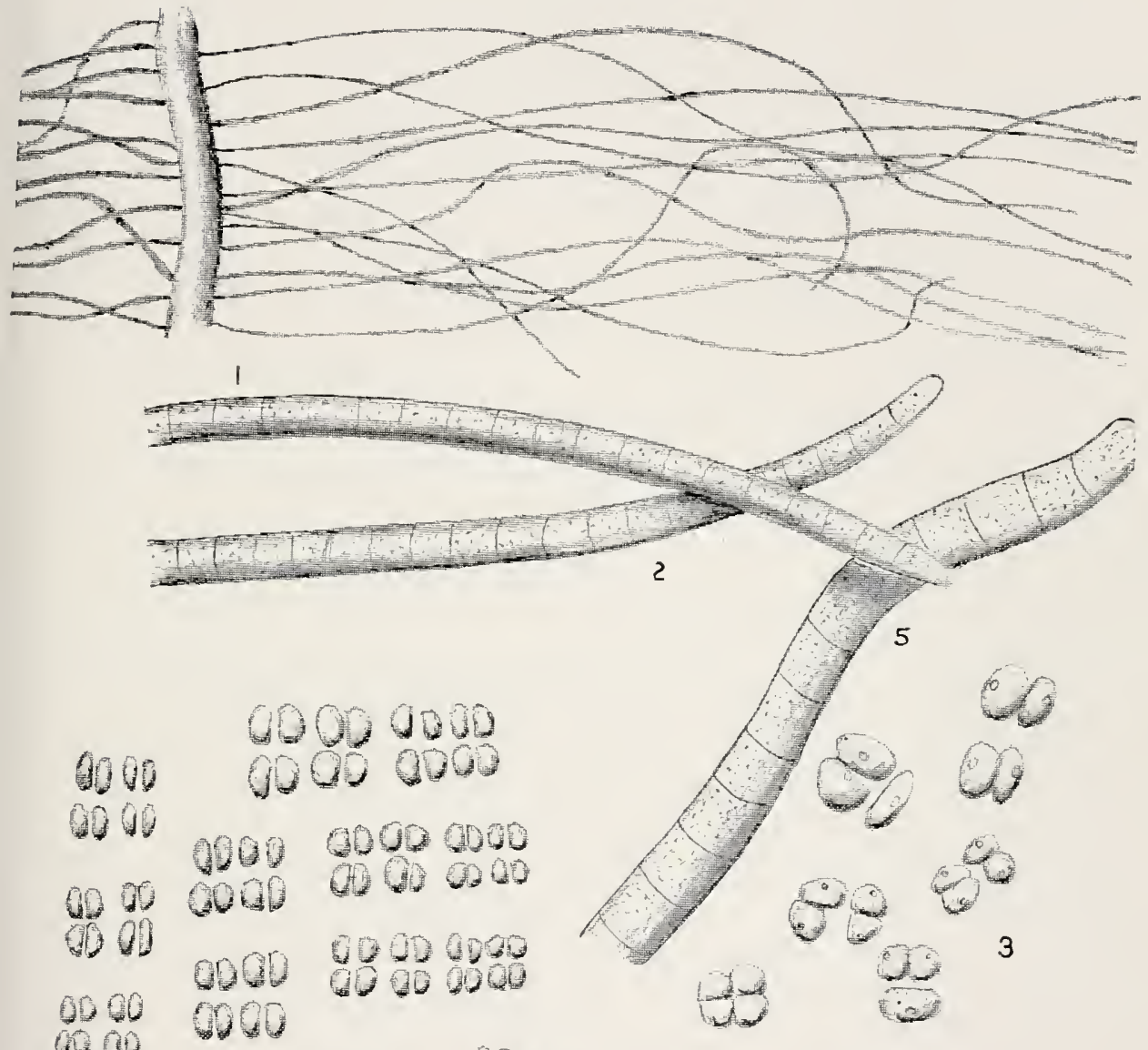

0000

$00000000 \quad 0000 \quad 0000$

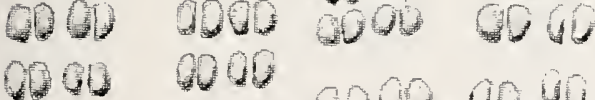
00000000 $\begin{array}{lll}0000 & 0000 & 00000000 \\ 6000 & 0000 & 4\end{array}$ $63000=$

20009004 00009000 0000 QOQ

4 
Plate II: Figlies 7 to ro: All (except Fig. Sa) MligniFIED IOOO DIMIETERS.

Fig. 7. Colospharium Kuctsingianum Näg. page I3 Fig. 8. Glaocapsa arenaria (

Fig. Sa. ". " A mass of the plant. natural size

Fig. 9. Microcystis aruginosa Kütz. (?). - In a mucilaginous mass .

Jïg. ya. Microcystis aruginosa Kütz. Without the mucilagino:1s mass

Fig. Io. Aphanocapsa Groillici (Hass.) Rab. “ " It 
of 0

0.6000

1. 00,0

150.000

Bo 0.000

3000000000

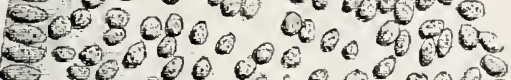

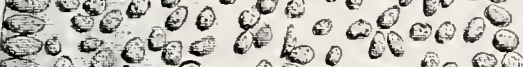
ENO 000000 1000 . 00 - 98 ec ato 10000000000

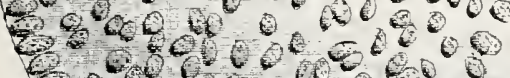
Co 0000000

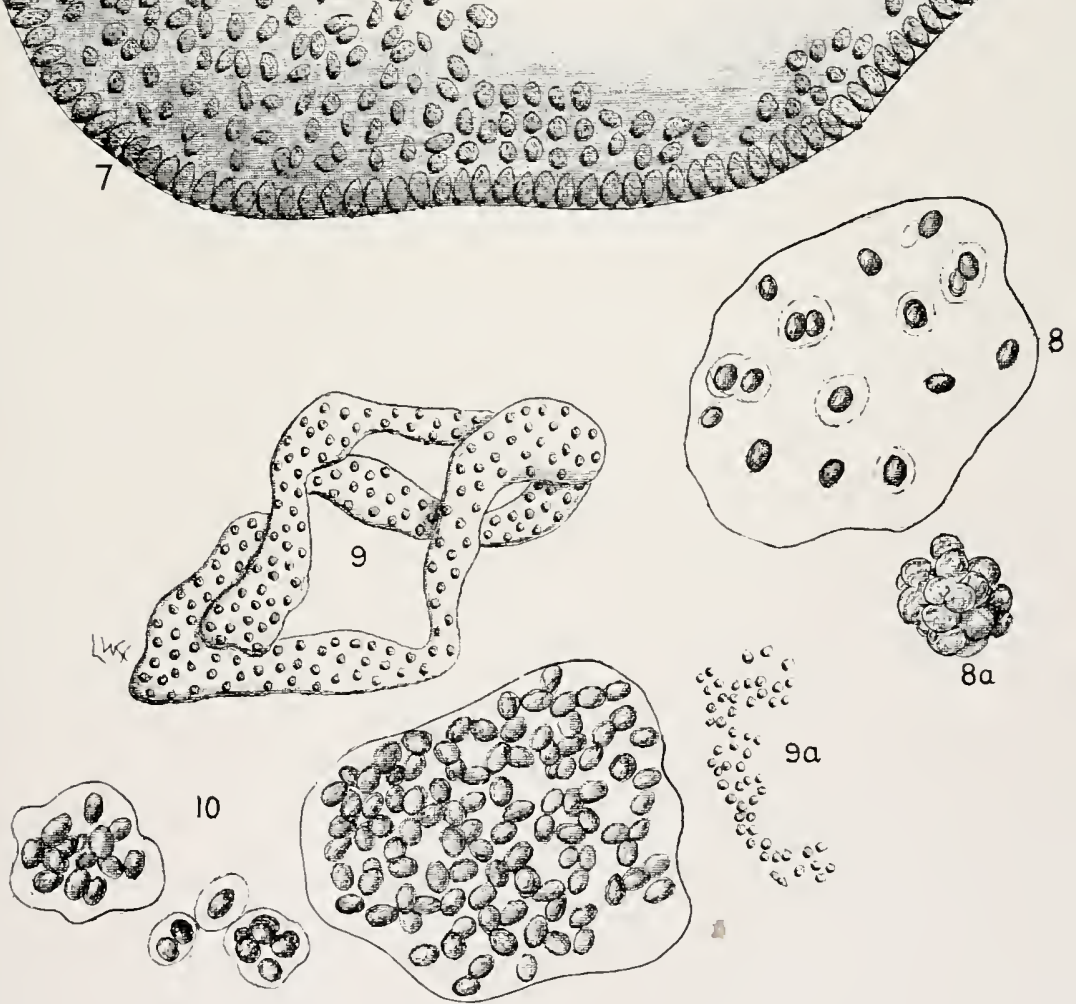


Plate III; Figures il to I5; All Magnified 1000 DiAMETERS.

Fig. 1. Anabana gigantea Wood . page 22 Fig. I2. " Flos-aqua Kütz. or circinalis (Rab.) Kirch. . . . . . . . . . " .

Fig. I3. Ly'ngbya sp. (?) . . . . . " “ 19

Fig. It. Oscillatoria chalybea Mertens . $\quad$.

Fig. I5. " amhlibia Ag. . . . . 


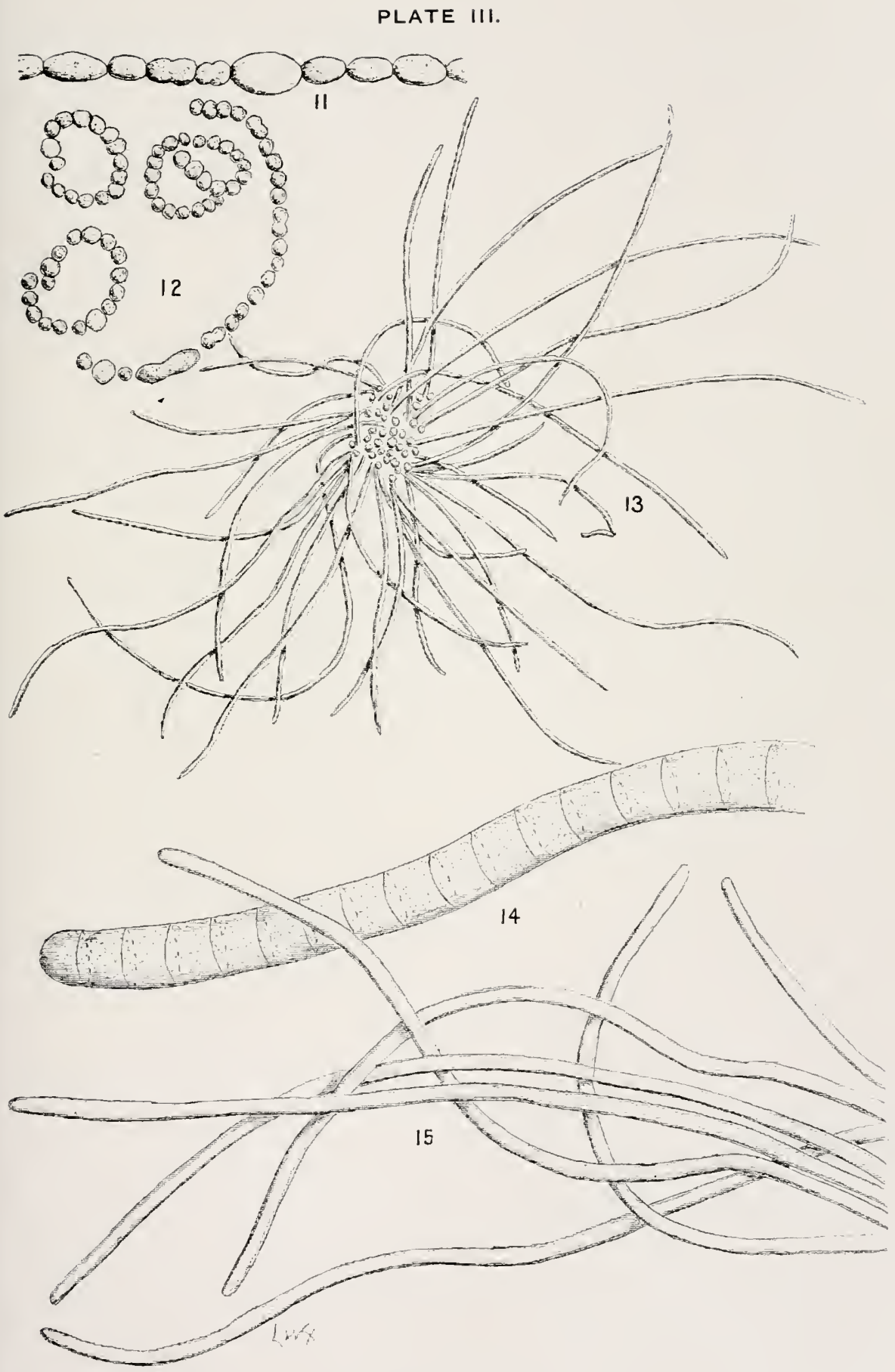


Plite IV; Figures 16 to 19 ; Fig. 18 Magnified 500 DianETERS; THE CTHERS IOOO DIMMETERS.

Fig. 16. Nostoc rupestre Kütz. . . . page 2I

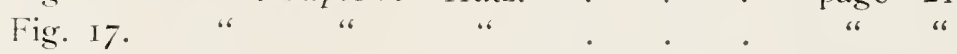
Fig. I8. " Fig. Iy. " comminutum Kütz. . . “ “ 
PLATE IV.

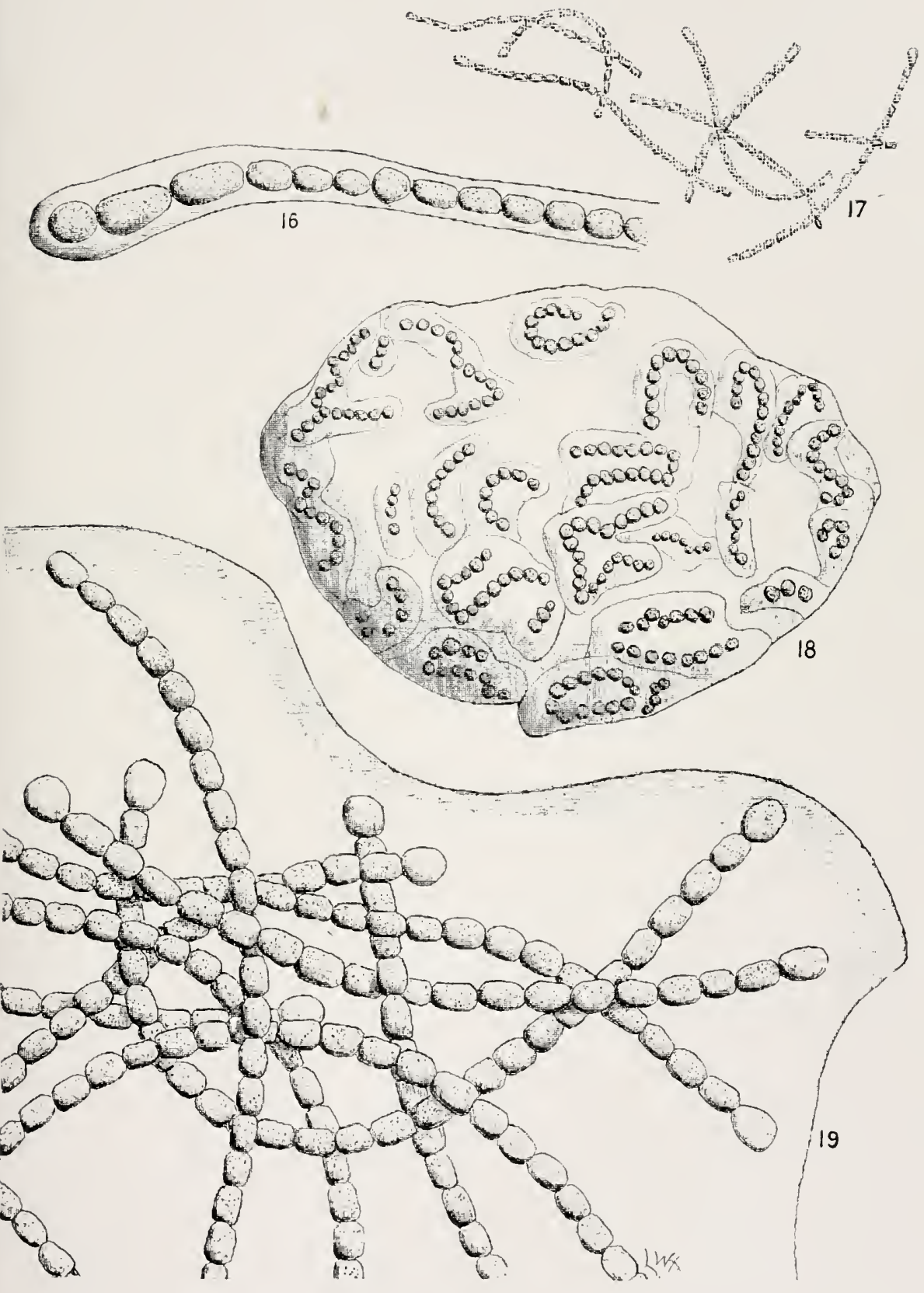


Plate T: Figures 20 to 29; Figs. 26 ANo 29 Migatified 500 Diameters; ALL Others ioOO Diameters.

Fig. 20. Ophiocytium paralum (Perty) A. Br. page 26 Fig. 2I. Triboncma minus (Wille) Haz. . ". 26 Fig. 22. Dictyospharium Ehrenbergianum Näg. ". 32 Fig. 23. Tetracdron minimum (A. Hir.) Hansg. " 33

Fig. 2+. $\quad$. trigonum var. punctutum ( Kirch.)

Fig. 25. Tetraedron trigonum var. pentagonum (Rab.)

Fig. 26. Nephrocytium Naegelii A. Br. .

Fig. 27. " Agardhiantm Näg. . . " “

Fig. 28. Glaocy'stis a'esiculosa Näg. . . . . . 29

Fig. 29. Nephrocytium Nägclii .A. Pr. . . . " 33 
PLATE V.
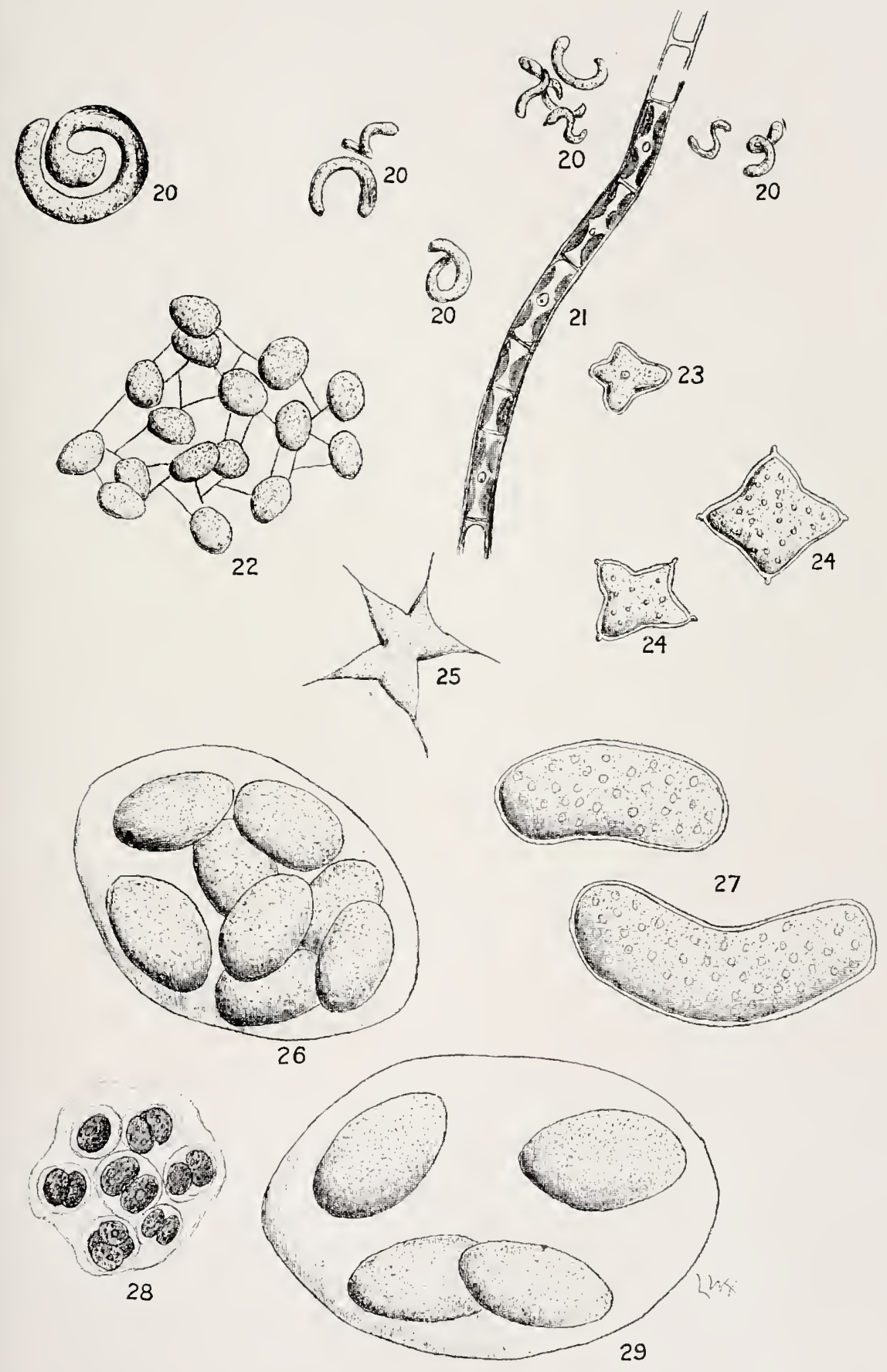
Plite VI: Fingres 30 to 49 : All Magxified 1000

DIMMETERS.

Fig. 30. Palmellocoecus sp. ( $\vdots$ ) . . . page 34

Fig. 31. ․ Gigas (Kütz.).

Fig. 32. Sconodesmns caudatus var. abundans Kirch. . . . . . . . . . 35

Fig. 33. Scenodesmus candatus var. typicus Kirch.

Fig. 34. Secnodesmus candatus var. sctosus Kirch.

Fig. 35. Secnodesmus sp. (

Fig. $36 . \quad$.. eandatus Corda

Fig. 37. ‥ acutus Meyen

Fig. 38 . ‥ obtusus Meyen

Fig. 39. " antennatus Breb. var. rectus Wolle

Fig. +o. Ankistrodesmus Brannii (Xäg.) (?)

Fig. +I. ". falcatus var. mira-

\section{bilis West}

Fig. 42. Secnodesmus dimorplus Kütz. .

Fig. 43. Sclenastrum sp. (?).

Fig. H. Scenodesmus dimorplus Kütz.

Fig. 45. Ankistrodesmus falcatus (Corda) Ralfs.

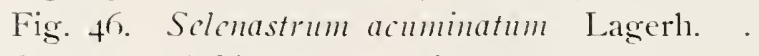

Fig. 47. Ankistrodesmus falcatns rar. acicu-

$$
\text { laris West }
$$

Fig. 48. Triboncma bombycinum (Ag.) Derbes and Sol. . . . . . . . . . 26

Fig. 49. Sccnodesmus sp. (?) . . . . . " $\quad 35$ 
Plate Vi.

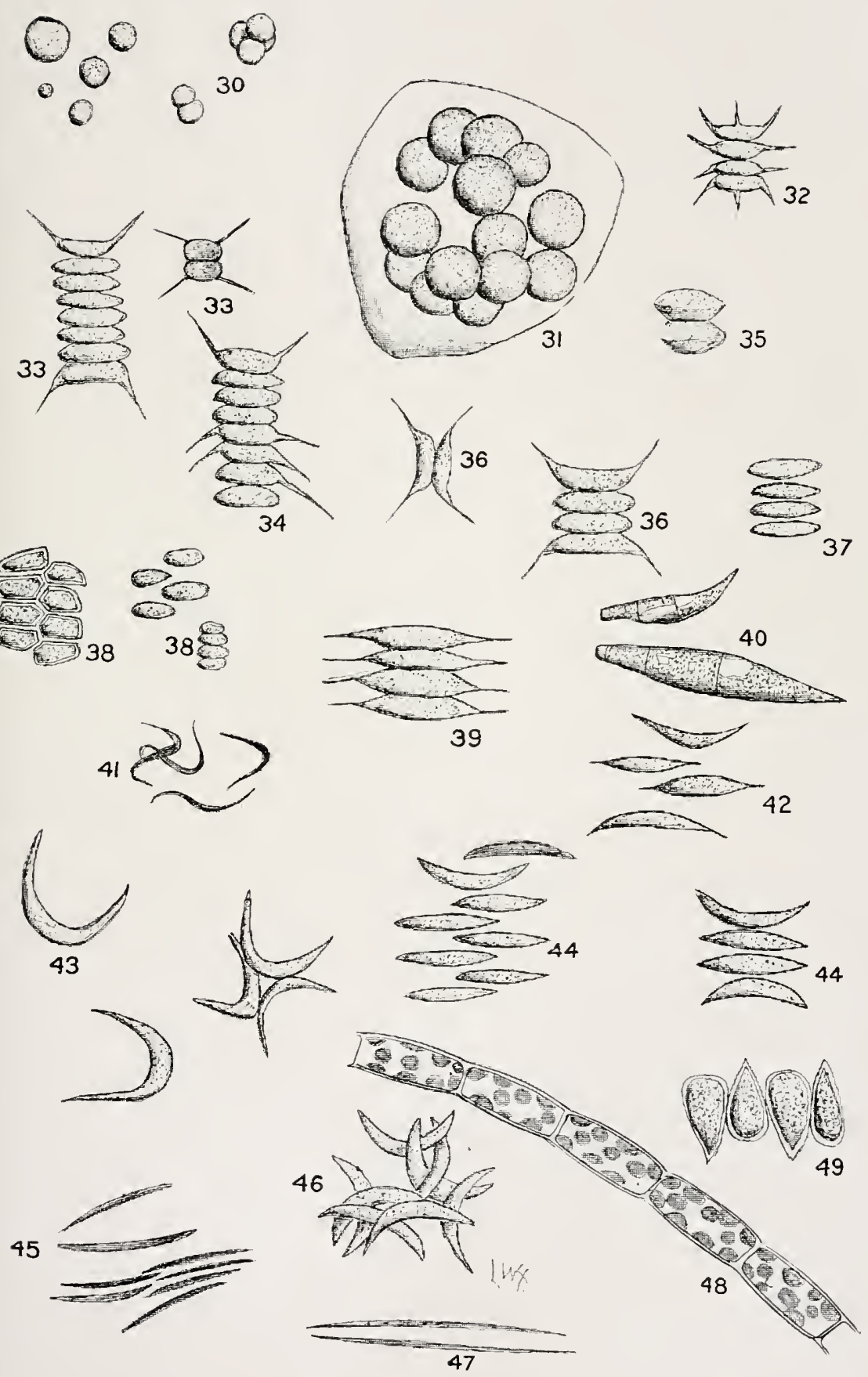


Plate VII Figures 50 to 56 : All except Fig. $5+a$ Mlagatfied iooo Diameters.

Fig. 50. Pediastrum pertusumu var. clathratum

A. Br. . . . page 38

Fig. 51. Colastrum micropornm Näg. . . " " 36

Fig. 52. Pediastrum pertusum var. clathratum

A. Br. . . . . . . . " 38

Fig. 53. Characium Nacgelii A. Br. . . . " 39

Fig. 54. Kirchucriclla obesa (West) Schmidle.

Fïg. $54 a$ represents a single cell . " “ 34

Fig. 55. Sorastrum spinulosum Näg. . . . " " 37

Fig. 56. Characinul ambigutum Herm. . . " " 39 
PLATE VII.
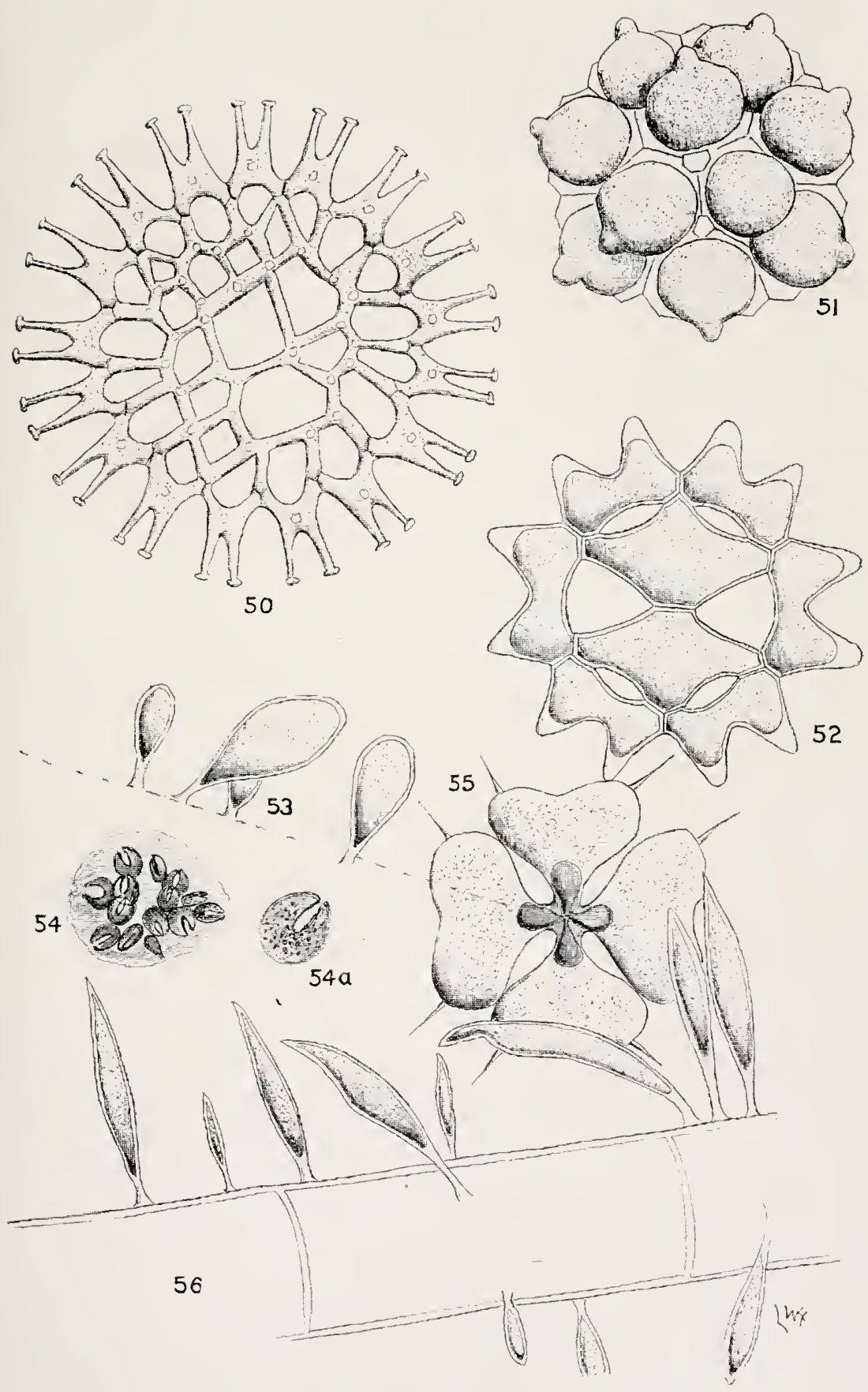
Plate Vill; Figures 57 to 60: All Magnified 500 DiamETERS.

Fig. 57. Pediastrum pertusum var. clathratum A. Br. . . . . page $3^{8}$ Figs. 58, 59. Pediastrum Borganum (Turp.) Meneg. var. gramilatum Kütz. . " " Fig. 6o. Spirogyra crassa Kütz. . . . . . " " 67 

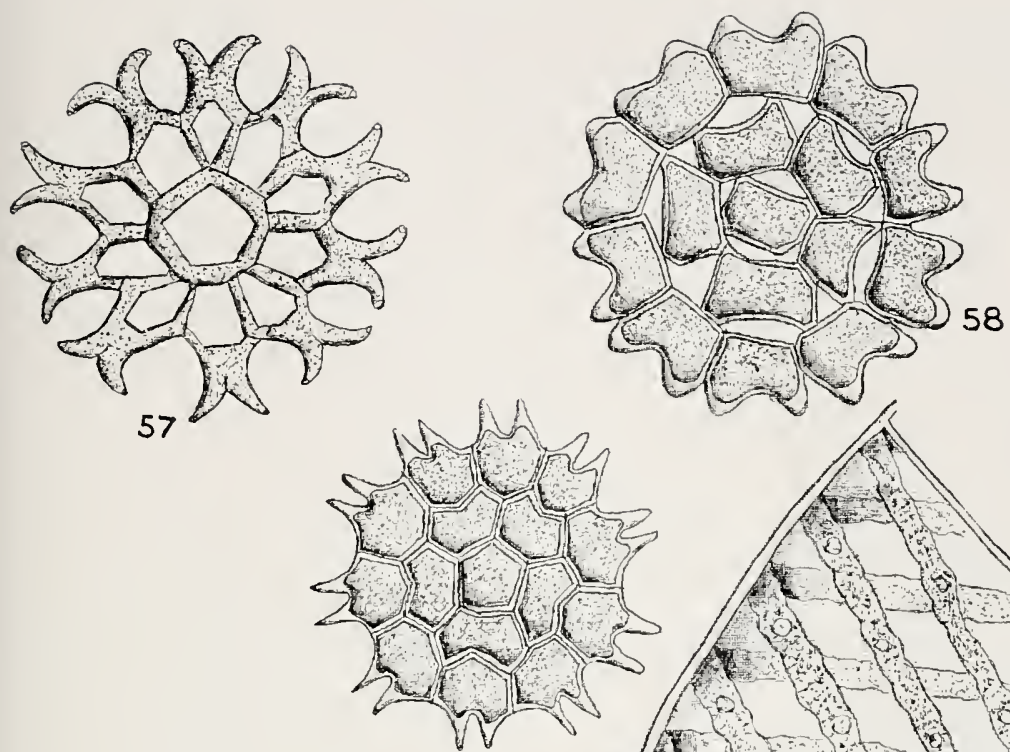
Plate IX; Figures 6 i to 7 i ; Fig. 68 Magnified 500 DianETERS; ALL OTHERS IOOO DIAMETERS.

Figs. 6I-63. Pediastrum Ehrenbergii A. Br. . page 38 Fig. 64.

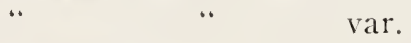

Fig. 65. Pediastrum sp. (?)

Fig. 66. " pertusum Kütz.

Fig. 67. " Boryanum (Turp.) Meneg. var. granulatum Kütz.

Fig. 68. Pediastrum pertusum Kütz.

Fig. 69. " tetras Ehrb.

Figs. 70,71 . " pertusum Kütz. 


\section{PLATE IX.}

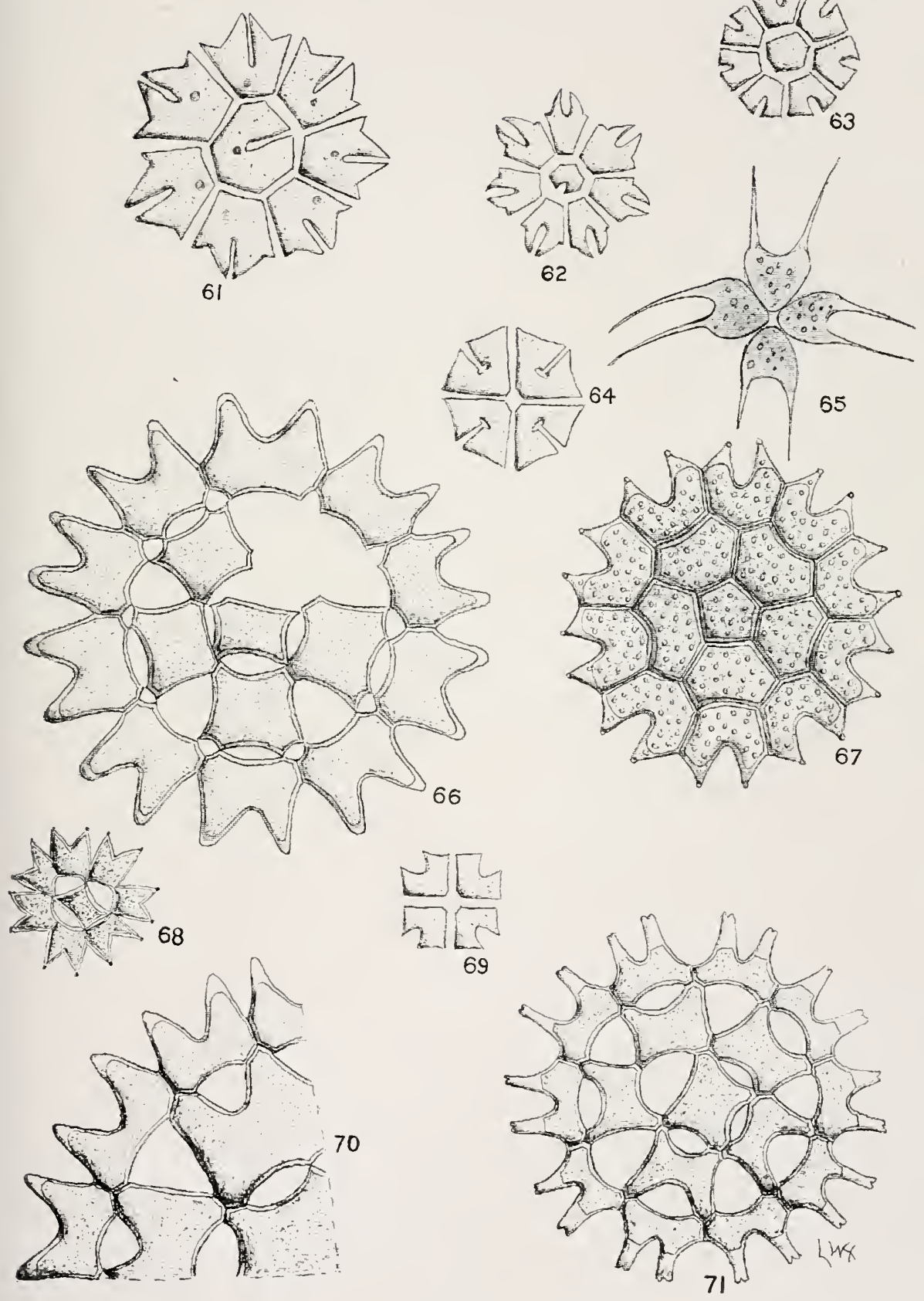




\section{P'LAte X; Figures 72 to 77 .}

Fig. 72. Palmella mucosa Kütz. (?) (250 diameters) . . . . page 30

Fig. 72a. A colony of the same, natural size .

Fig. 73. Pleurococcus vulgaris Menegh. (500

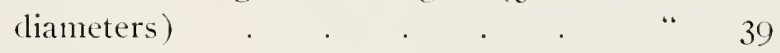

Fig. 74. Tolio.t. A young colony. (500 diameters) . . . . . . . . .

Fig. 75. I'olion aurcus Ehrb. (200 diameters) “" “"

Fig. 76 . " globator Ehrb. (125 diameters)

Fig. 77. Titraspora gelutinosa (Vanch.) Desv. ( 250 diameters) . . . . . . 30

Fig. 77a. A colony of the same, natural size . . " " 
PLATE $X$.

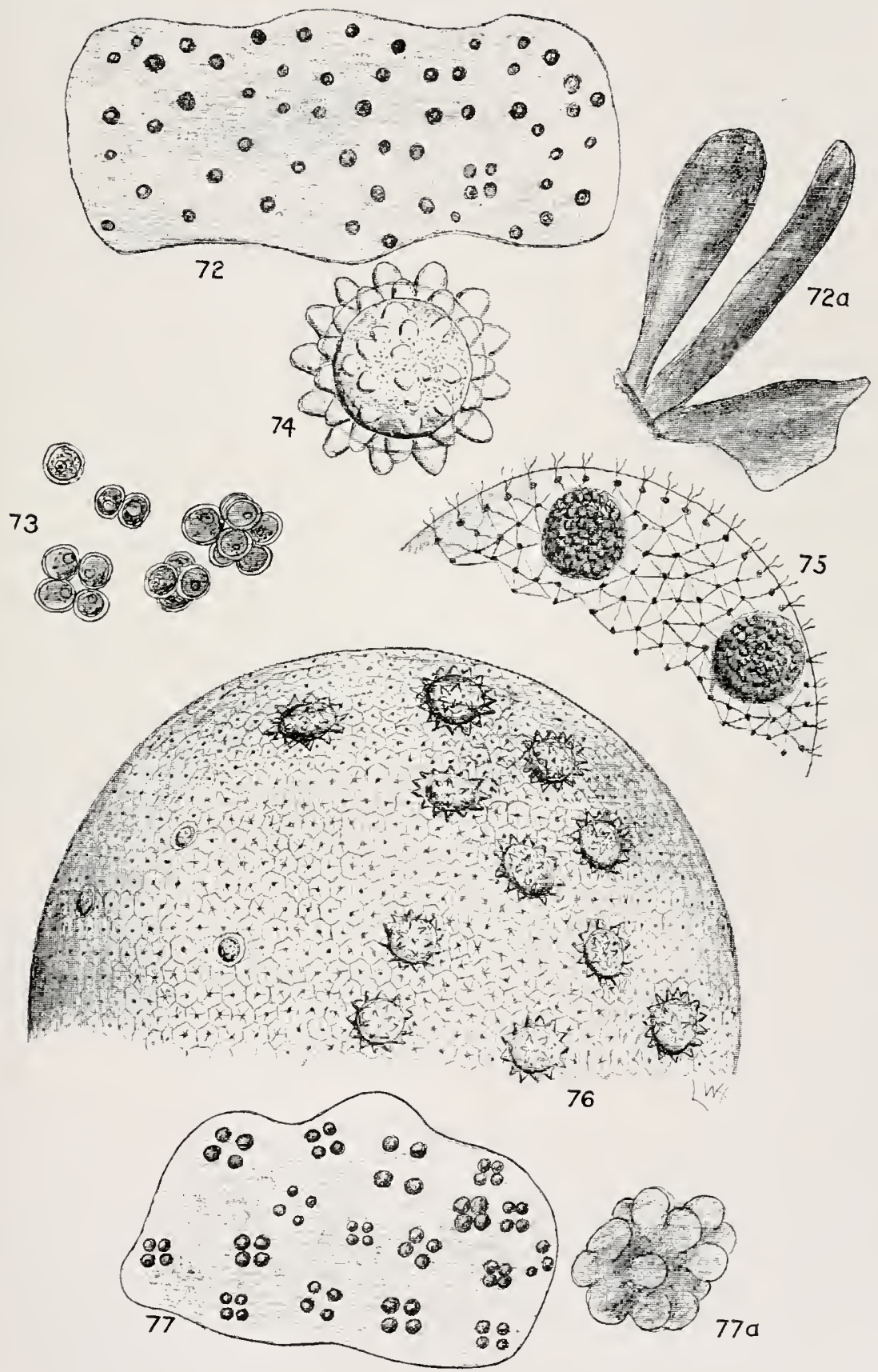


Plate AI; Figlese 78, 79; Mugnified 250 Dimaeters.

Fig. 78. Myronema sp. (?) . . . . page 47 Fig. 79. ". tenue (Ag.) Rab. . . “ “ 
Plate Xil; Figures 80 to 82 .

Fig. Soa.Coleochate irregularis Pringsh. (?) (250 diameters) . . . page 5I

b. Herpostciron Confericicola Näg. . " 50

c. Diatom . . . . . .

Fig. 8I. My'ronemalubricum var. zarians Haz.

(500 diameters) . . . . . . . 47

Fig. 82. My.roncma tenuc (Ag.) Rab. (250 (liameters) . . . . . . . . 
PLATE XII.

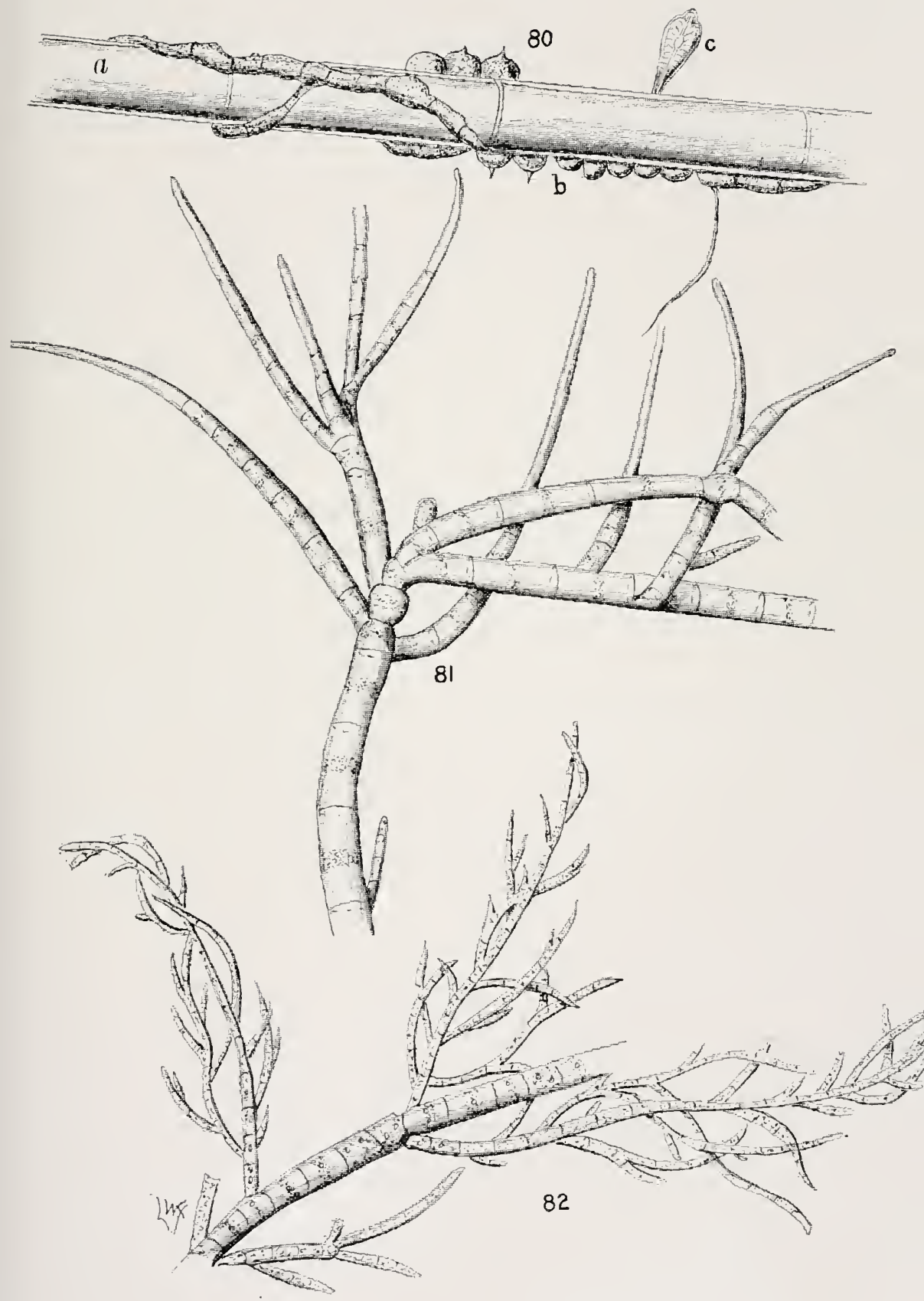


Plate Xili; Figlres $8_{3}$, $\$_{4}$; Magnified ioo Diameters. Figs. 83. 84. Draparnaldia plumosa (Vauch.) Ag. . . . . page 48 
PLATE XIII.

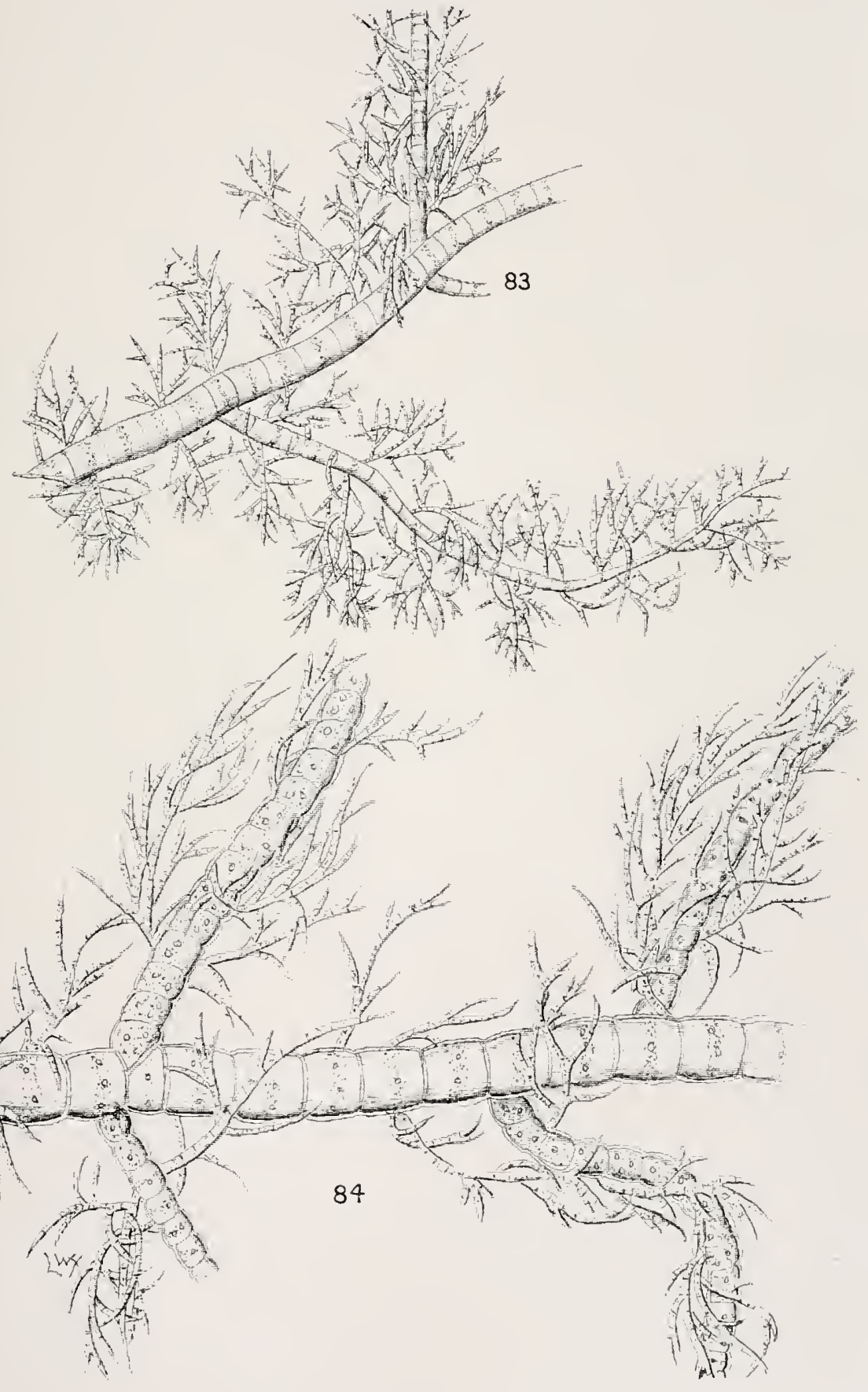


Plite XIV: Figures 85 to 89.

Fig. 85. Mougeotia sp. (?) (5oo diameters) . page 68 Figs. 86 to 80. Ulothrix sp. (?) ( Iooo dianeters, except $86 a$, which is 500 (liameters) 
PLATE XIV.

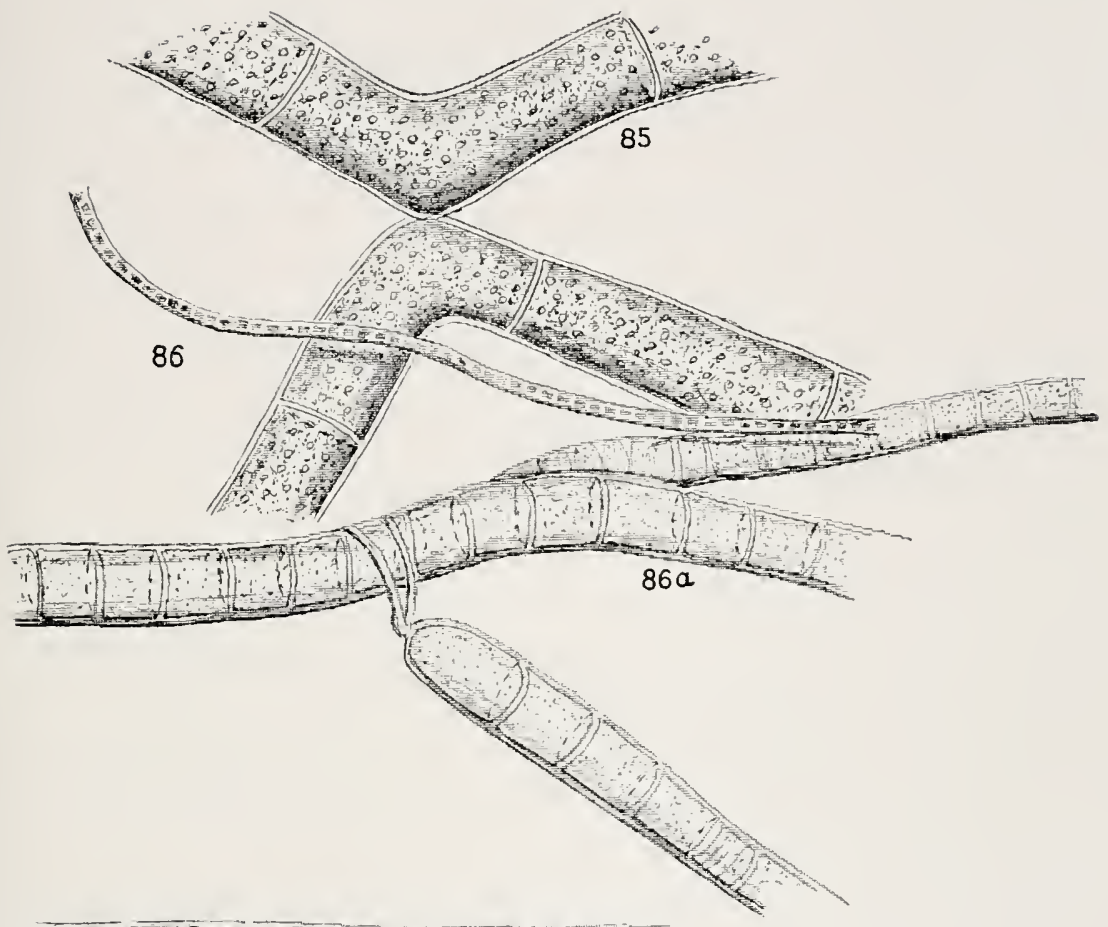

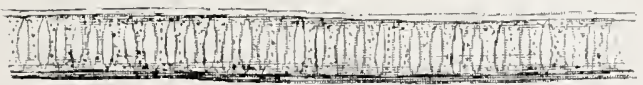

\section{7}

ar a

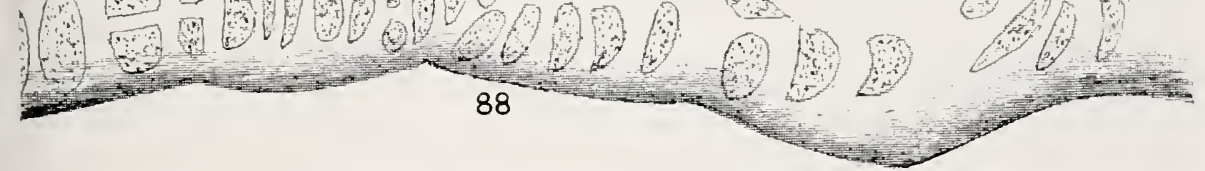

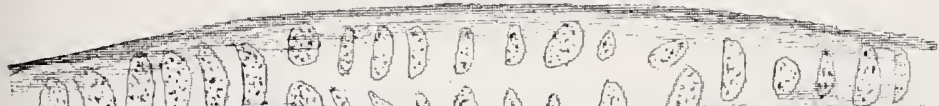

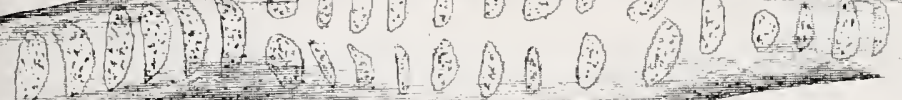

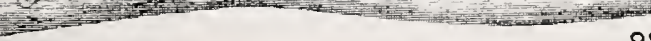


Plate XV; Figures 90 to 95 : Magnified iooo Diameters, EXCEPT Fig. 9I.

Fig. 9o. Ulothrix. Young stage . . . page 49 Fig. 91. " " " (low power) " " Fig. 92. Microspora Stagnorum (Kütz.) Lag. " 50 Fig. 93. Ulothrix tenerrima Küitz. . . " " 49 Fig. 94. " zonata (Web. and Mohr) Küitz.

Fig. 95. Ulothri.r sp. (?) 
PLATE XV.
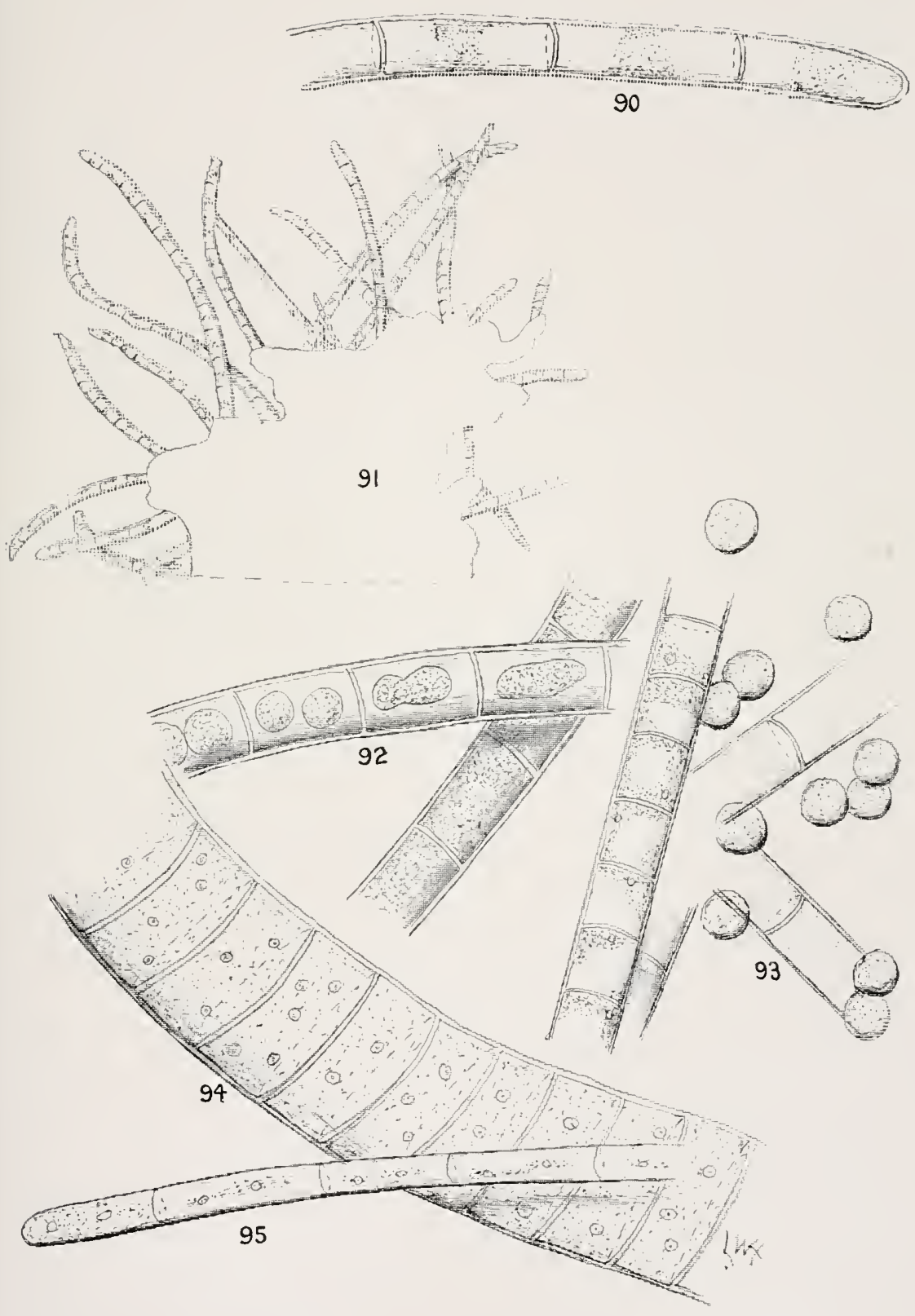
Plate XVi; Figures 96 to 98 ; Magnified iooo Diameters. Fig. 96. Edogonium sp. (?) . . . . . page $5^{2}$ Fig. 97. Bulbochate sp. (?) . . . . " " Fig. 98. " " . " . " 
PLATE XVI.

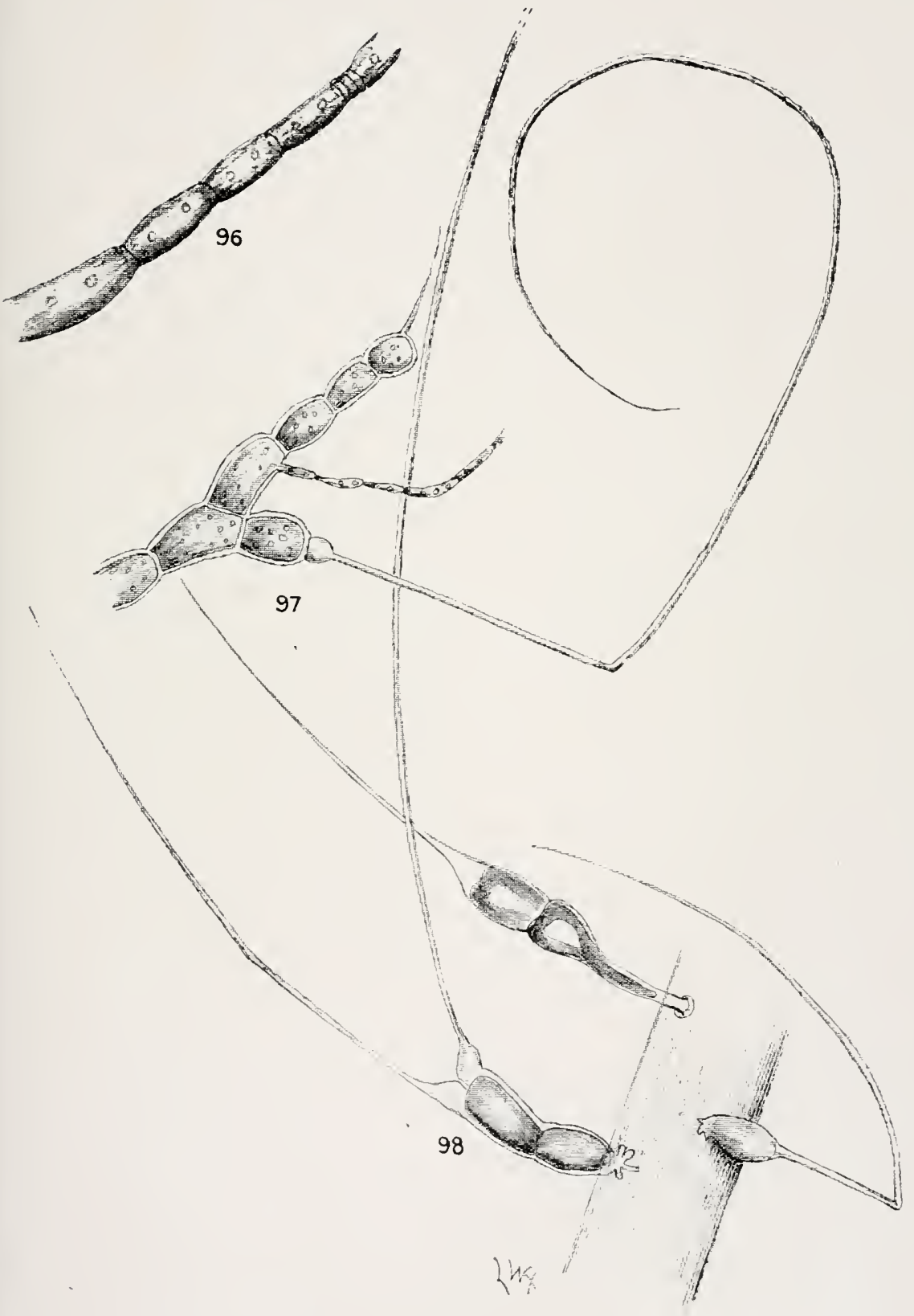


Plate Alil Fugres 99 to IOz; Mlagified 1000 DIAMETERS.

Fig. 99. Cosmarimm Broomci Thwaites . page 6t Fig. 100. ". tunidum Lund. . . . . " .

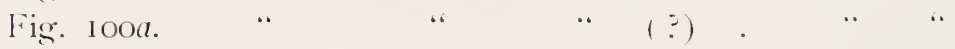
Fig. IOI. Plcurotanimull sp. (?) . . . . . " " Fig. 102. Cosmarimu ormatum Ralfs . . . " 61 Fig. ı03. Pleurotanium Baculum Breb. . . " . Fig. Iot. Euastrum a'crucosum (Ehrb.) Ralfs " 62 Fig. I05. " integrum Wolle . . " . 
PLATE XVII.

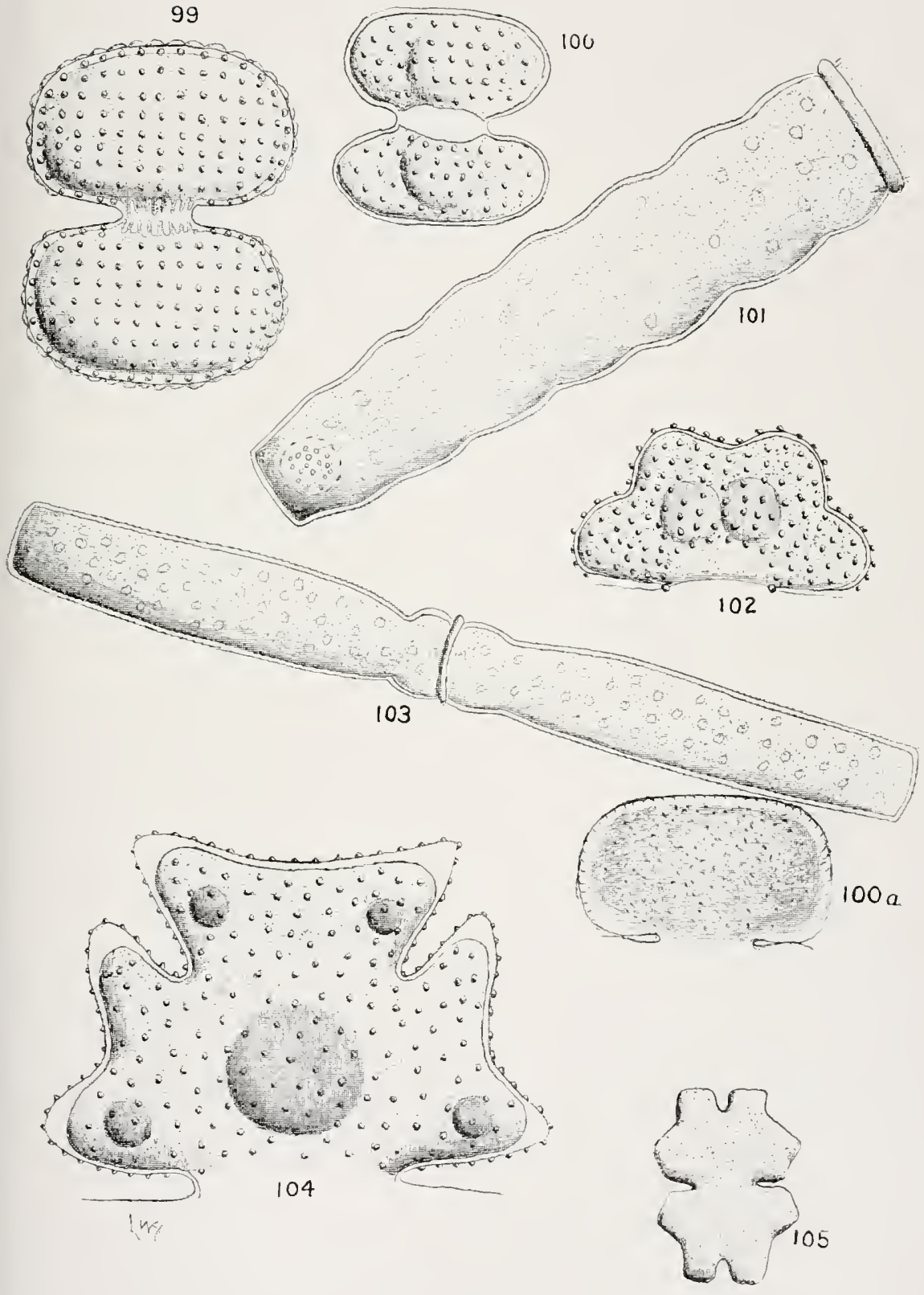


Plate Nifil: Figures 106 to io8: Fig. 107 M.ıgnified iooo Dicmeters: others 500 Dicheters.

Fig. 106. Micrasterias radiosa (Ag.) Ralfs var. punctata West . . page 63 Fig. 107. Micrasterius Crut-1/elitensis (Ehrb.) Hass.

Fig. 108. Micrasterias apiculata Menegh. 


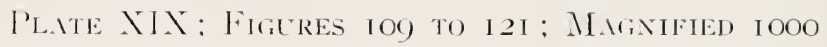
DIAMETERS.

Fig. Ioy. Cosmarimm grmatum Breb. . . page 64

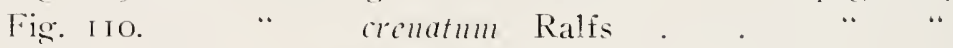

Figs. I1I, I12. Cosmarimm sp. (?) .

Fig. II3. Cosmarimu suborbiculare Wrood . . . . Fig. 114 . $\quad$ sp. (?) . . . . . . . .

Figs. I г, i 16 . Cosmarimm Botrytis Menegh. ". Fig. II\%. Cosmarium contractum Kirch. . . . . . Figs. II8, пा\%. Splecrozosma filiforme Rab. . ". .

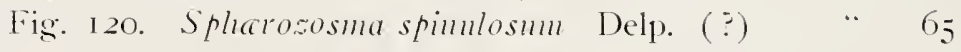
Fig. 12I. Tuntlidinm fasciculatmm var. subalpinum Wolle . . . . . . . $\quad 66_{4}$ 
PLATE XIX.

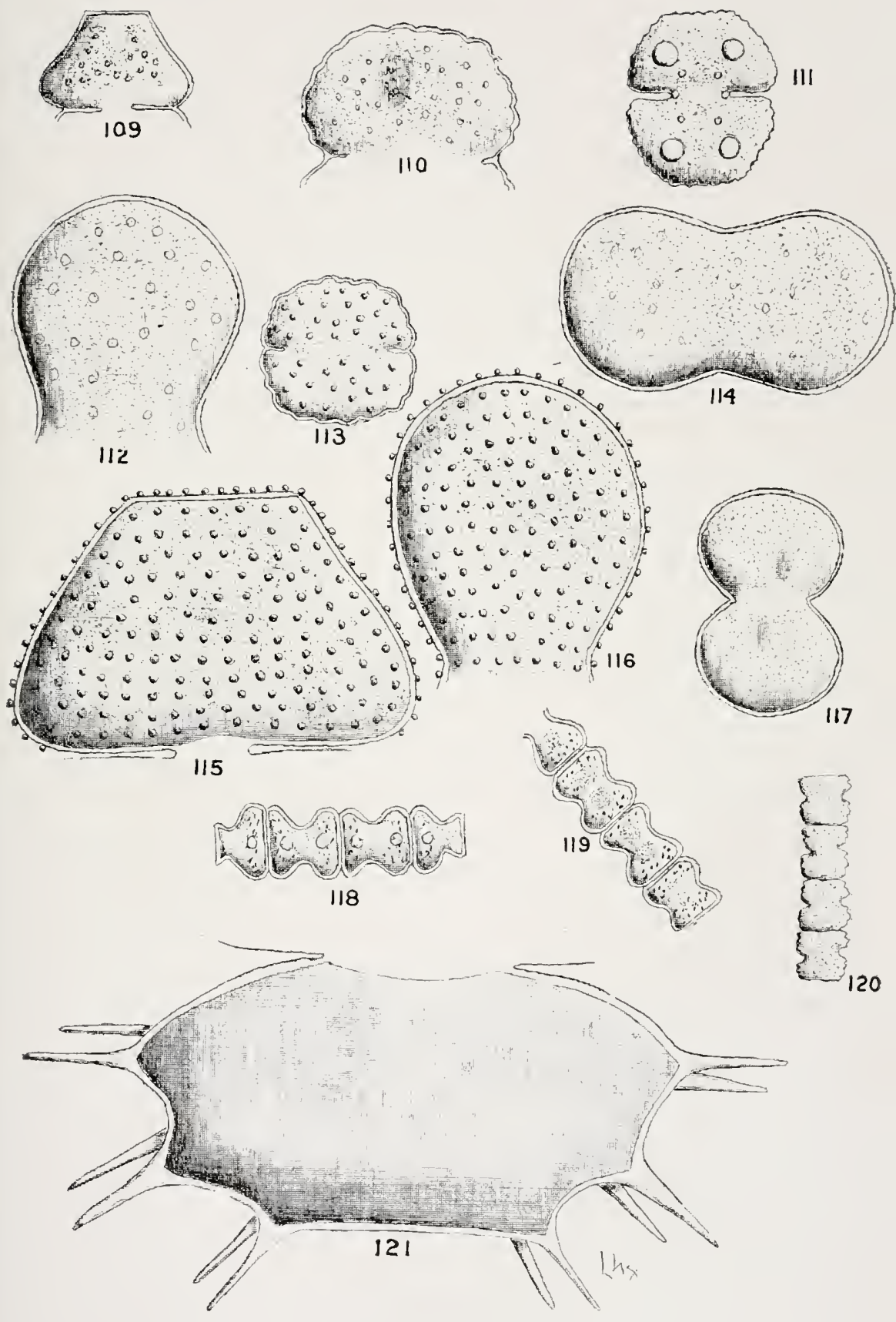


Plate XX; Figites 122 to I33: Mhagrified iooo Dinmeters.

Fig. 122. Staurastrum dejectum var. conergens Wolle. . . . . page 62

Figs. 123, 124. Staurastrum orbiculare (Ehrb.) Ralfs.

Fig. 125. Staurastrum de jectum var. mucronatum Ralfs

Figs. 126, 127. Staurastrum megacantlutm Lund.

Fig. I28. Staurastrum brcitspinum Breb.

Fig. 120. $\quad . \quad$ muricatum Breb.

Fig. г зо. $\quad$ " crasum Breb.

Fig. I31. " " ing multiplication by division

Fig. 132. Staurastrum odonatum Wolle .

Fig. I33. ". hirsutum (Ehrb.) Breb. 
Plate NXI; Figlres I 34 to I H4; Magnified 1000 DIAMETERS.

Figs. I34, 135. Staurastrum Raienclii Wood (?) page 62 Fig. I36. Staurastrum furcigerum Breb. . " " Figs. I.37-I +2. Staurastrum species undetermined " " " Fig. I43. Staurastrum iotanum Wolle . . " " " Fig. 1.4. ". custephanum Ralfs . . ". 
PLATE $X X I$.

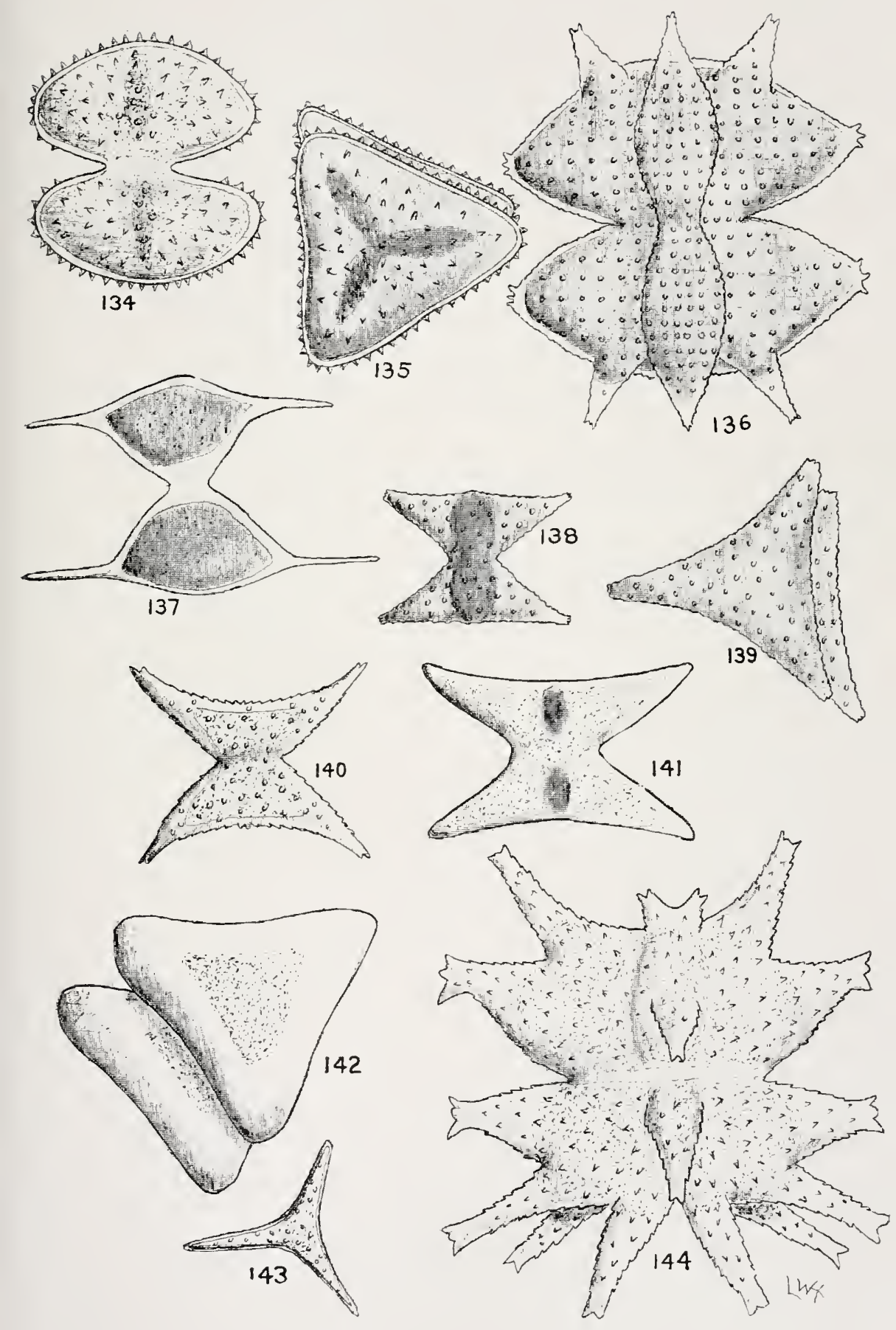


Plate XXII; Figures 145 TO I51; Figleses 147, 149 , I5 Magnified 500 Diameters; Others 1000 Dilmeters.

Figs. 145, 146. Roya obtusa (Breb.) West. page 60 Fig. I 47. Closterium acuminatum Kütz. . . . " . Fig. It8. ‥ lanccolatum Kütz.

Fig. If). ". Cucumis Ehrb. (?)

Fig. $150 . \quad$." accrosum (Schrank) Ehrb. (?). With fungous growth

Fig. 151. Clostcrium accrosum (Schrank) Ehrb. (?). About to divide. 


\section{PLATE XXII.}

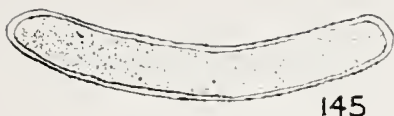

145

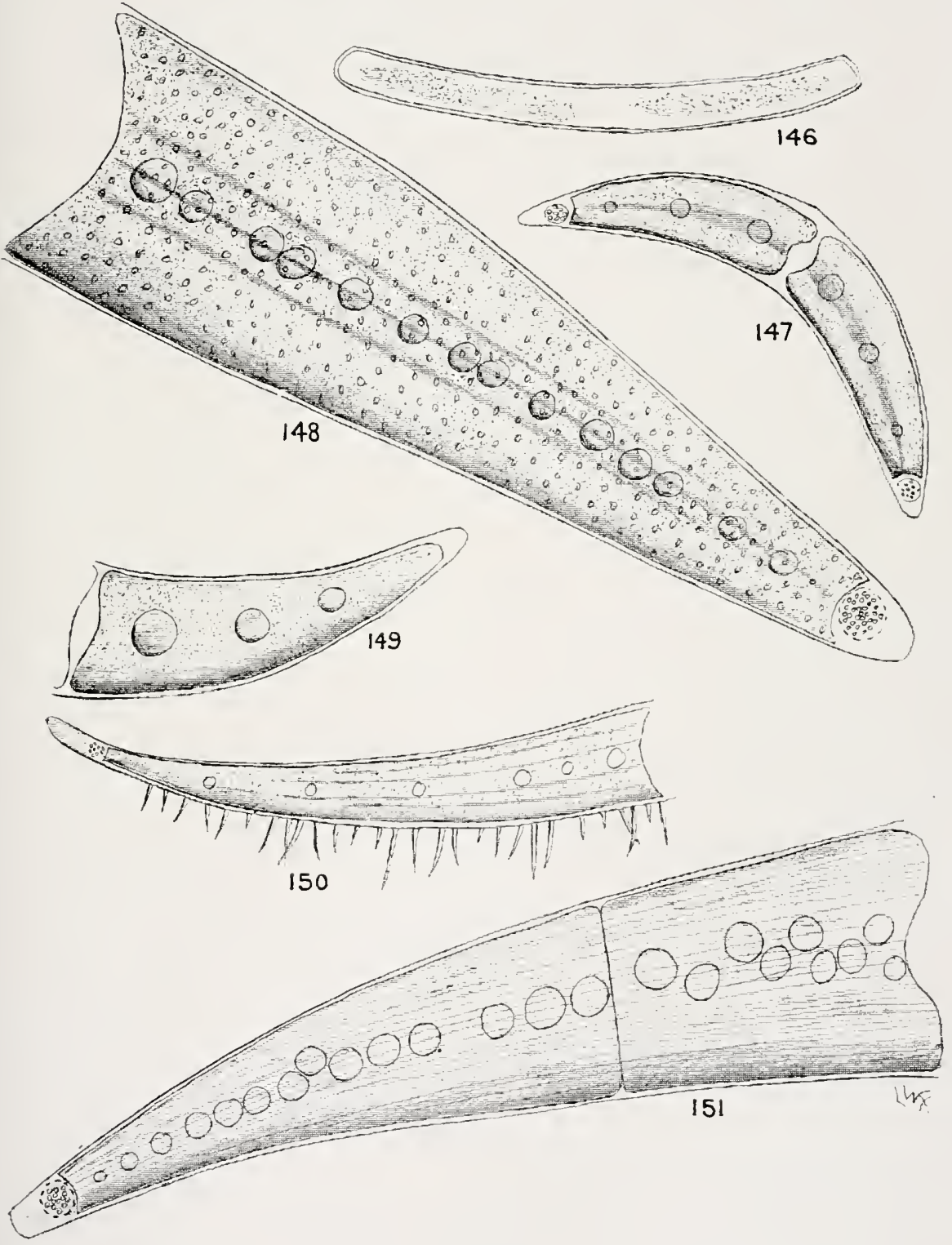


Plate XXili: Figleses 152 to i 59 : Figs. I52, 157, 158 Magnified 500 Dimaters; others iono Diameters.

Fig. 152. Closterinm Lunnla Ehrb. . . page 60 Fig. 153. . . turgidum Ehrb.

Fig. I54. " strigosum Ehrb.

Fig. 155. " costutum Corda

Fig. $156 . \quad$. Delpontci Klebs . . . . .

Fig. $157 . \quad$ ". prelongum (Preb.) Delp. ". 6I

Fig. 157a. .

Fig. 158 . .

$$
\text { tiplication by division }
$$

Fig. I5). Closterium decormm lireb. . . ...... 
PLATE XXIII.

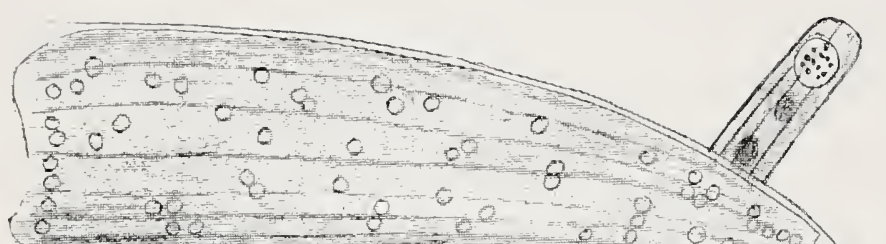

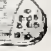

- 10000

$\frac{0}{x+2+\infty} 153$
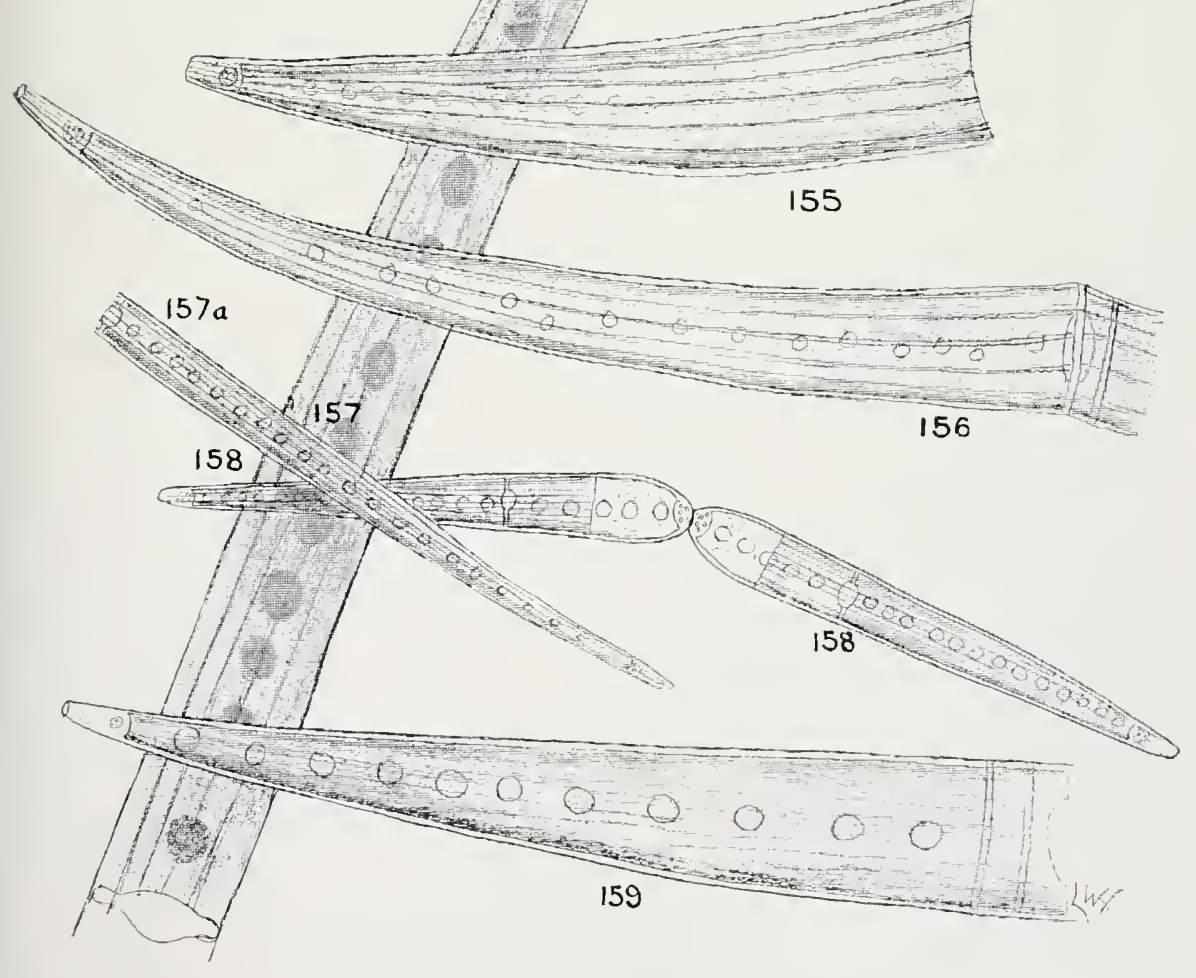
P'late XXiv; Figlikes ifo to i65; Maginified 1000 DiamETERs, Except Fig. i6i.

Fig. I60. Closterium Jenneri Ralfs. . . page 61

Fig. I61. ". areolatum Wood (500 diameters)

Fig. I62. Clostcrium Diance Ehrb. .

Figs. 163,164 . Closterium parculum Näg.

Fig. 165. Closterium moniliferum (Bory) Ehrb. " " 
PLATE XXIV.

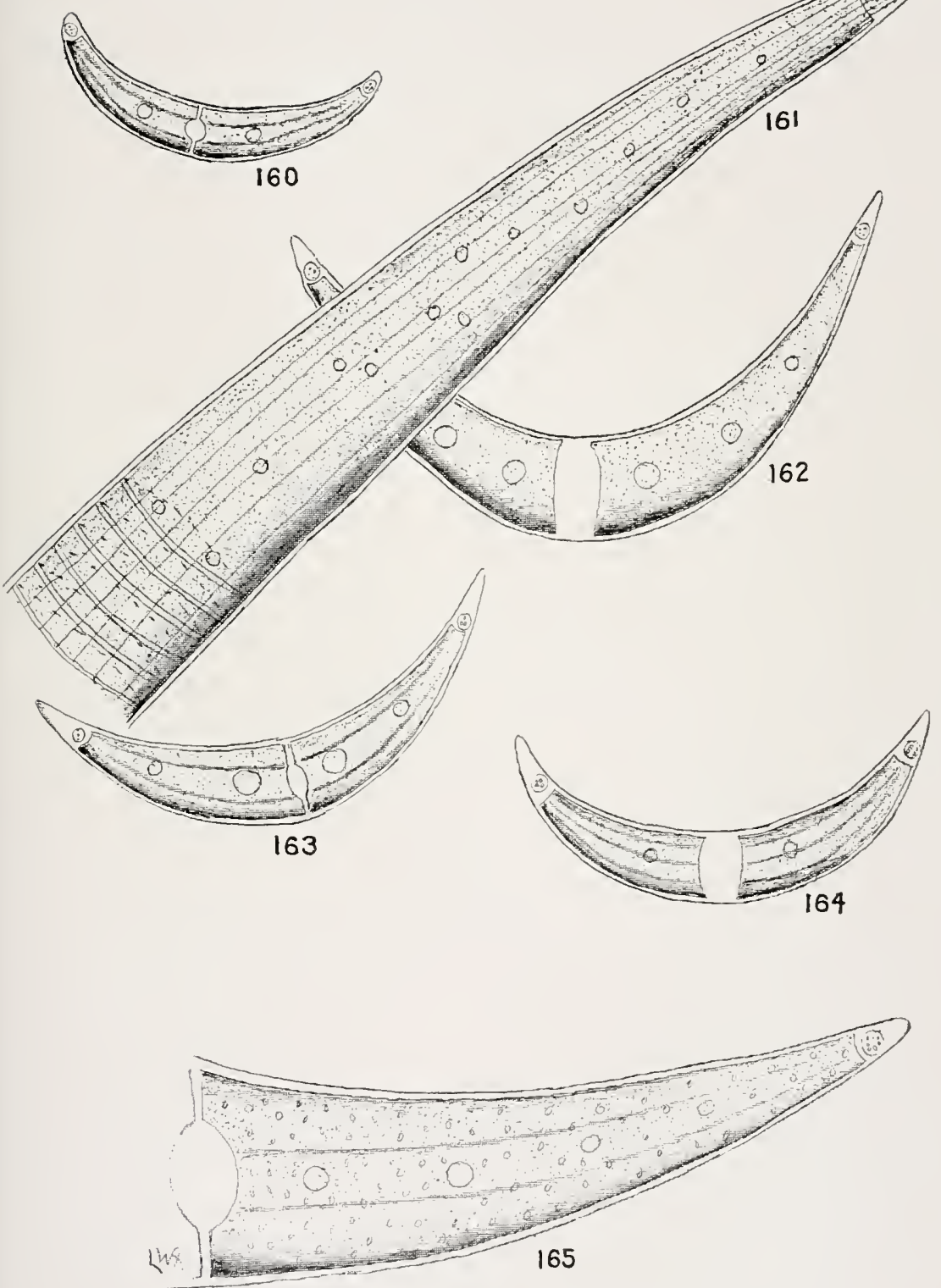


Plate NXI; Figures i66 to I7I: Figs. i68, i69 MAgnified 500 Dinmeters; all others iOOO Dhameters.

Fig. 166. Closterinm Lcibleinii Küitz. . . page 61 Fig. $167 . \quad$ " $\quad$ " var. curtum WTest " ". Fig. I68. ․ rostratum Ehrb. . . " " " Fig. I69. ". breitrostratum llest.

Fig. izo. Clostcrium subcostatum Nord. With only 6 costex.

Fig. г7г. Clostcrinun Brébissonii Delp. . 
PLATE $X \times V$.

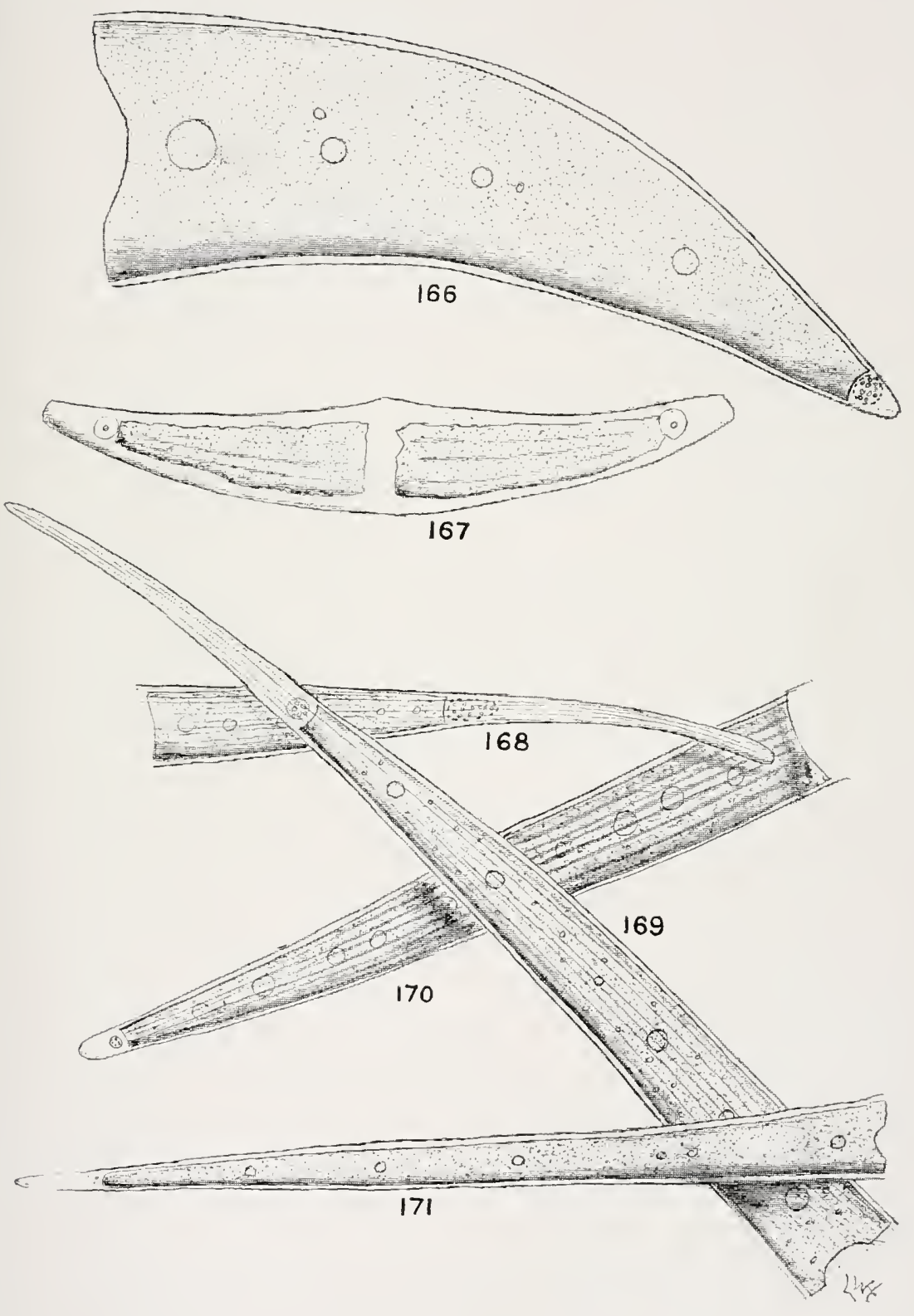




\section{Plite XXII; Figures i72 to I75: Magnified 1000 DIAMETERS.}

Fig. 172. Penium closterioides Ralfs . . page 60

Fig. 173. " polymorphum Perty . . . " .

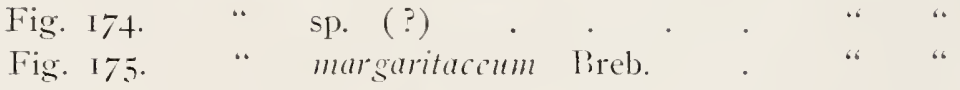


PLATE XXVI.
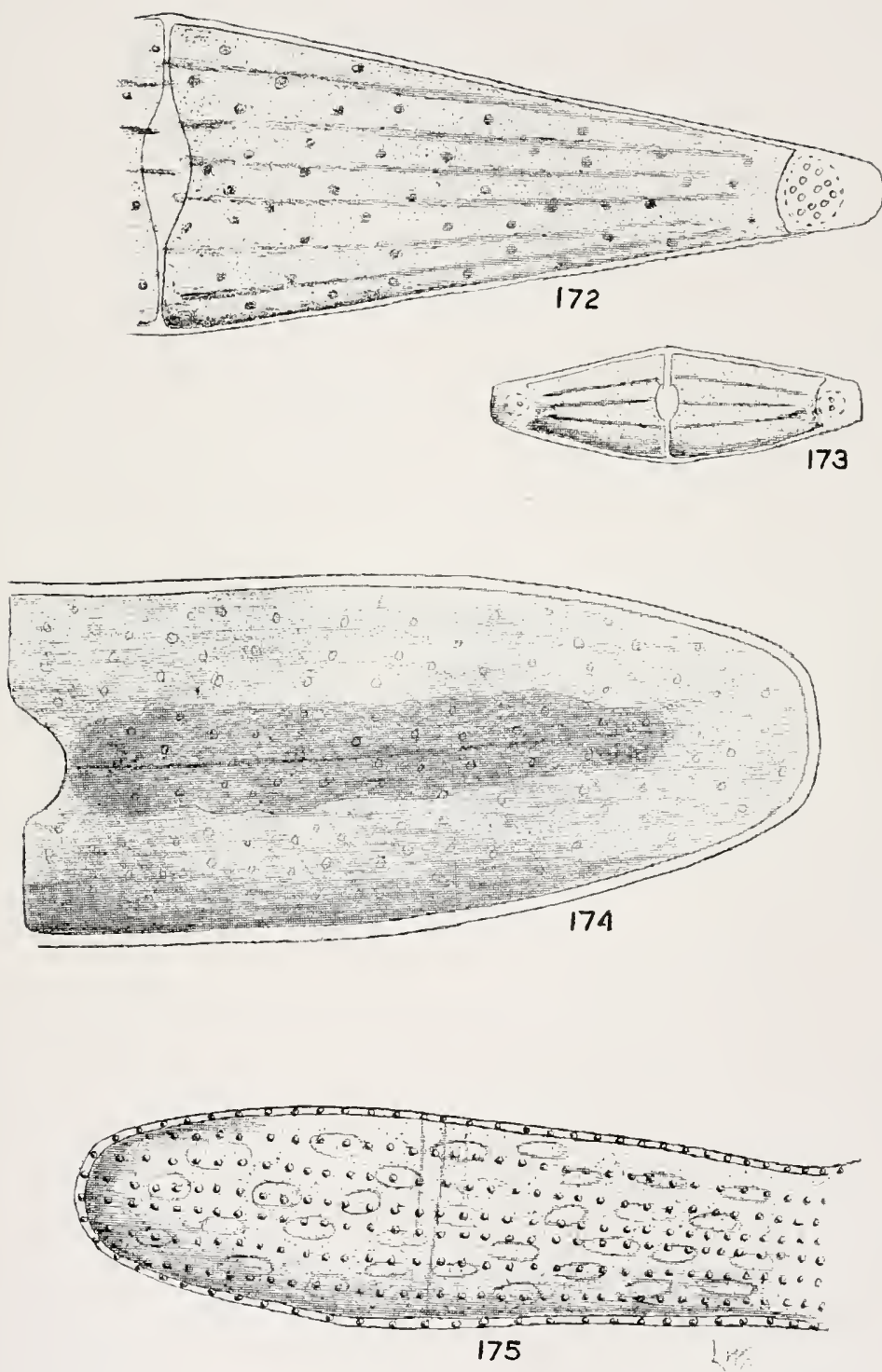
Plite XXYII; Figlres ij6 to iso; Magnified 500 DiAMETERS.

Fig. 176. Zygnema leiospermum D. Py. . page 66 Figs. 177, 178. Zygnema stellium Ag. . . “ “ Fig. 179. Zygnema stellium var. genumum

Kirch. .
Fig. ISo. Zygnema cruciatum (Vauch.) Ag. 
PLATE XXVII.
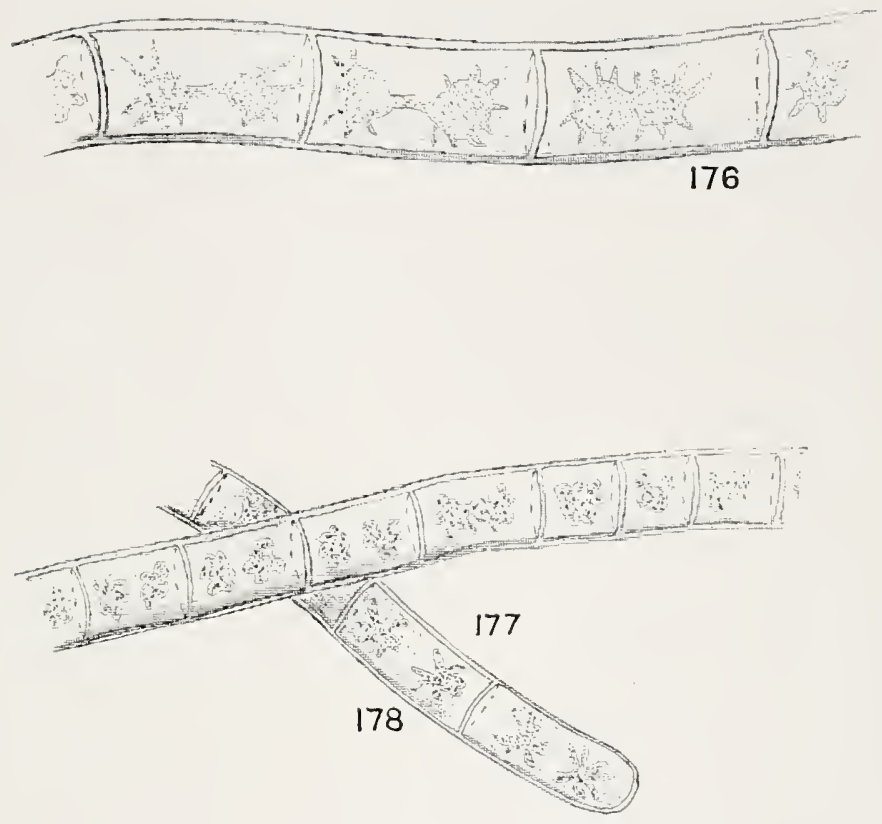

179

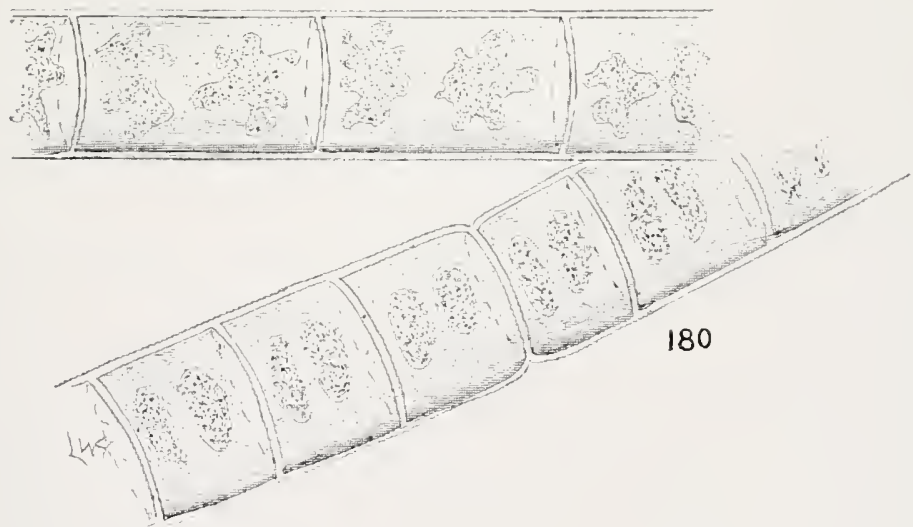


Plate XXYili; Figures i8I to i87; Figs. i82, i86 MagNified 250 Diameters; all others 500 Diameters.

Fig. I8I. Spirogyra zarians (Hass.) Kütz. . page 67 Fig. ${ }_{1} \&_{2}$.

\section{Conjugating}

Figs. I83, I84. Spirogyra W Veberi Kütz. . Fig. I85. Spirogyra marima (Hass.) Witt. Fig. 186. ‥ jugalis (Dillw.) Kütz. . Fig. 187. " "

Conjugating 
PLATE XXVIII.

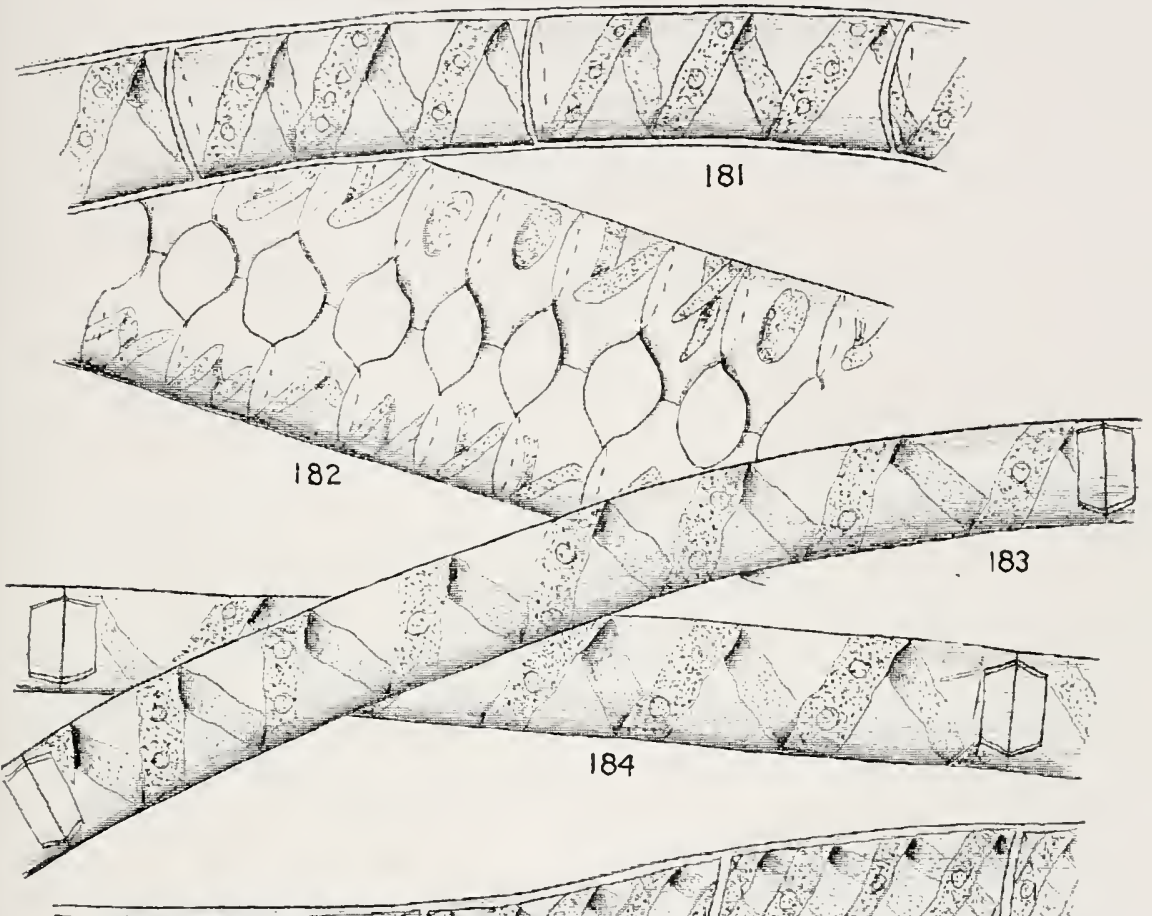

a

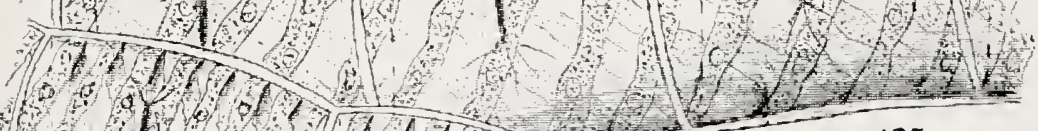

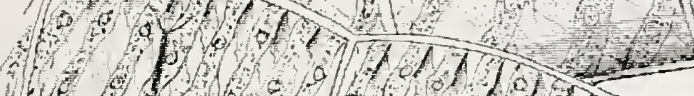

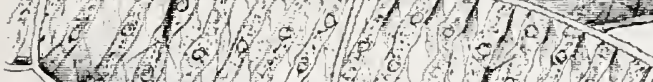


Plate XXIX; Figlres is8 to 196 ; Magnified 250 DIMMETERS.

Fig. I88. Spirogyra dubia Kütz. . . . page $6_{7}$ Figs. I89, 190. Spirogyra quinina (Ag.) Kütz. “. “ Fig. I91. Spirogyra Greilleana (Hass.) Kütz. “. “ Fig. IO)2. ". majuscula Kütz. . . * " Fig. I93. ‥ adnata Küitz. . Fig. 194. .. Spreciana Rab. Fig. I95. " " calospora Cleve Fig. Ig6. “ decimina (Mull.) Kütz. 

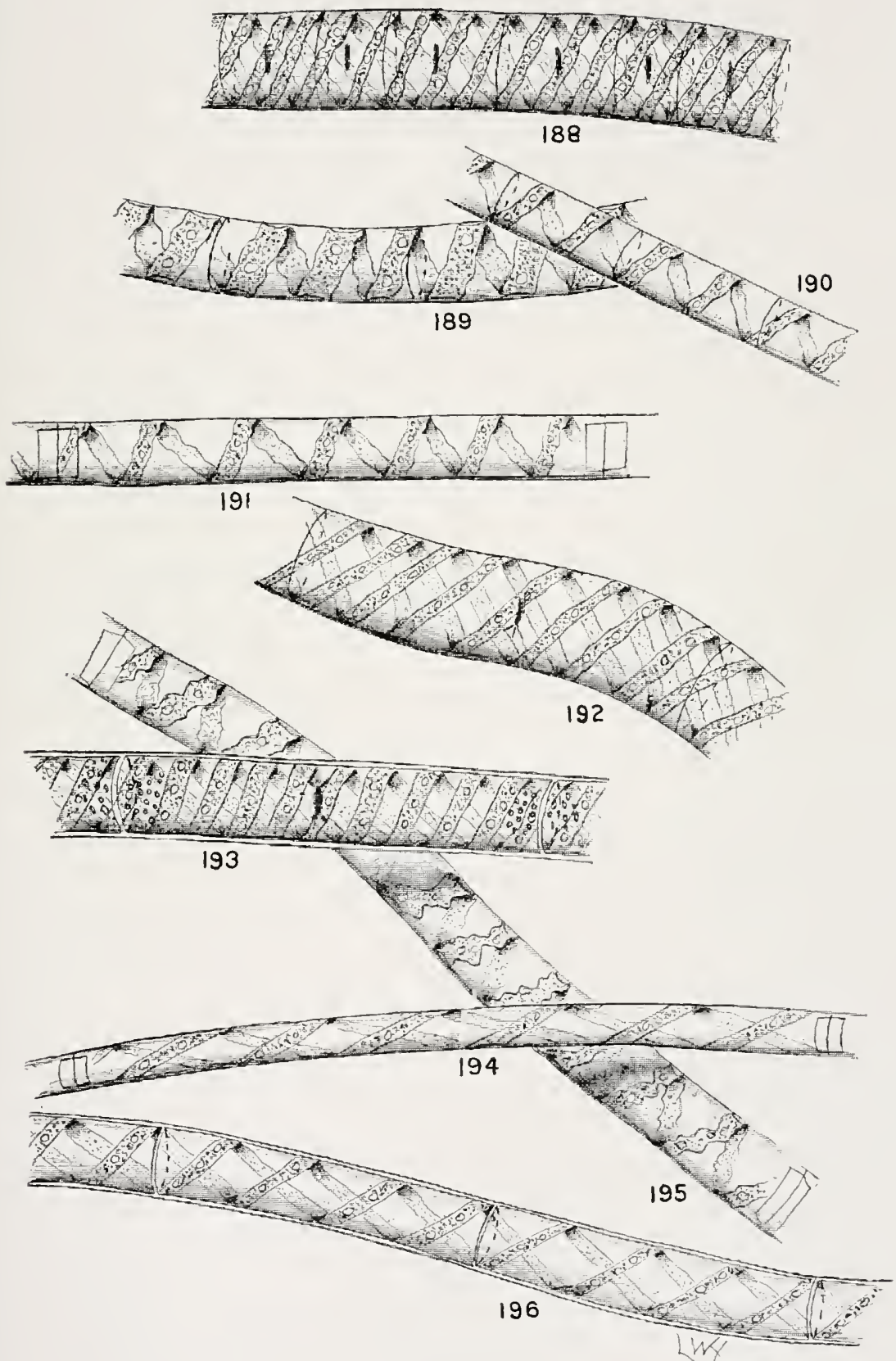
Plate XXX; Figleses ig7 to 206: Figures 197. 205 M.igNified 500 Diameters: All Others 250 Diameters.

Fig. 197. Sprogyra communis (Hass.) Kütz. page 67 Fig. 11,8. " Alnciatilis Hilse

Fig. 199. ". dishes, the cells elongating without dividing. and dancing dots of oil appearing in the encls

Fig. 200. T'aucheria sessilis (?) ( Vauch.) D. C. “ 55 Fig. 20I.

Fig. 202. Sfirogyra mirabilis Hass. . . . " " 67 Fig. 203. " bellis (Hass.) (leve. In state of decomposition . . . . . . 67

Fig. 204. Spirogyra bellis (Hass.) Cleve . “ “ Fig. 205. " flaz'escens (Hass.) Cleve “. “ Fig. 206. Fanchcria. Showing sexual organs. “ 55 


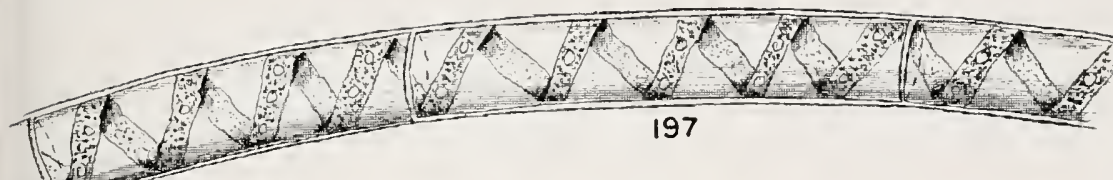

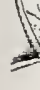

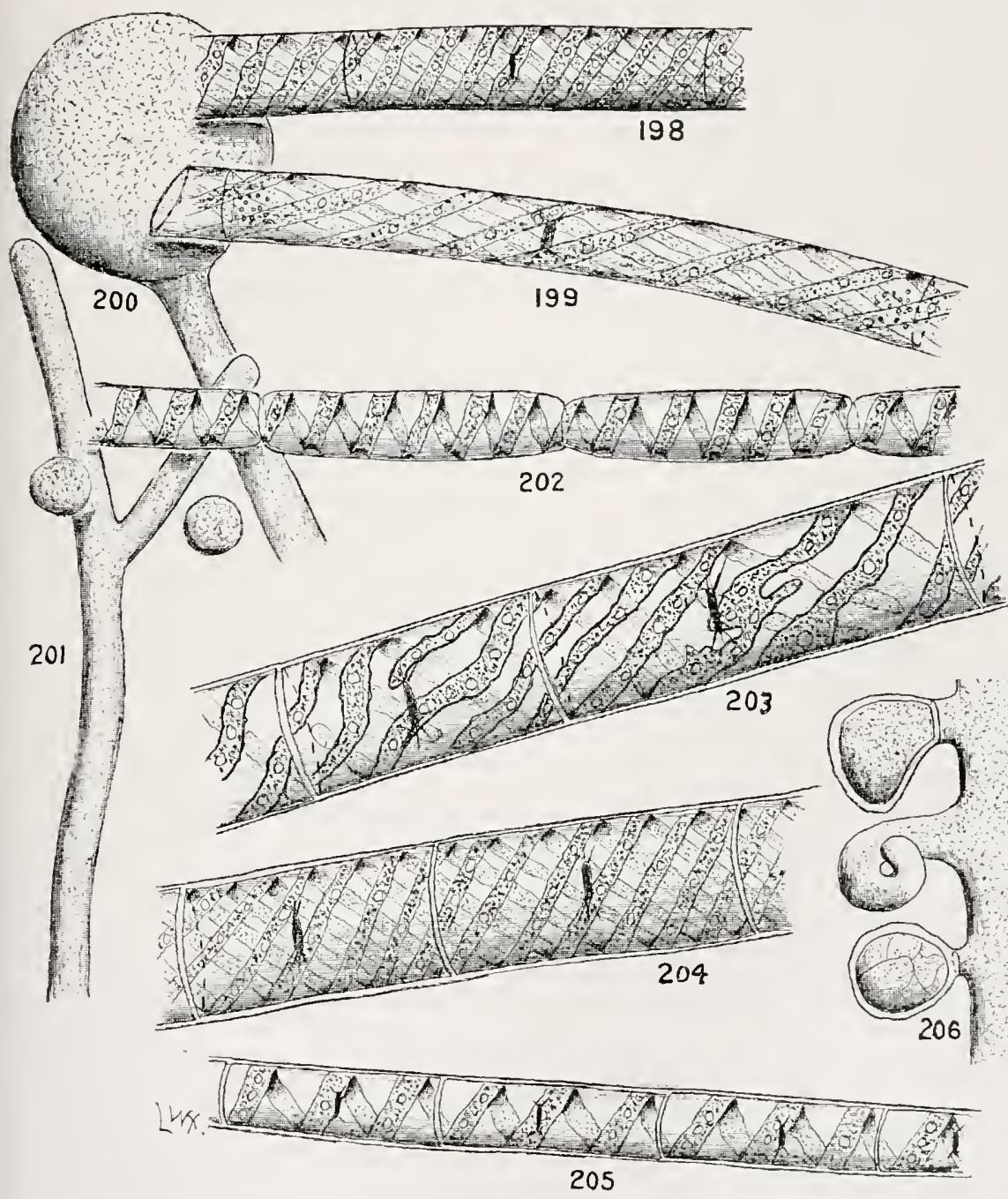


Plate XXXi: Figlres $20 \%$ TU 200.

Fig. 20\%. Chara sp. ( 3 ) Shield of antheri(limm ( 25 dianneters) . . page 69

Fig. 208. Chara sp. (?) A portion of the plant. natural size .

Fig. 209. Chara sp. (?). a. antheridium;

b, oögonium ( 5 o diameters). 
PLATE $X X X I$.

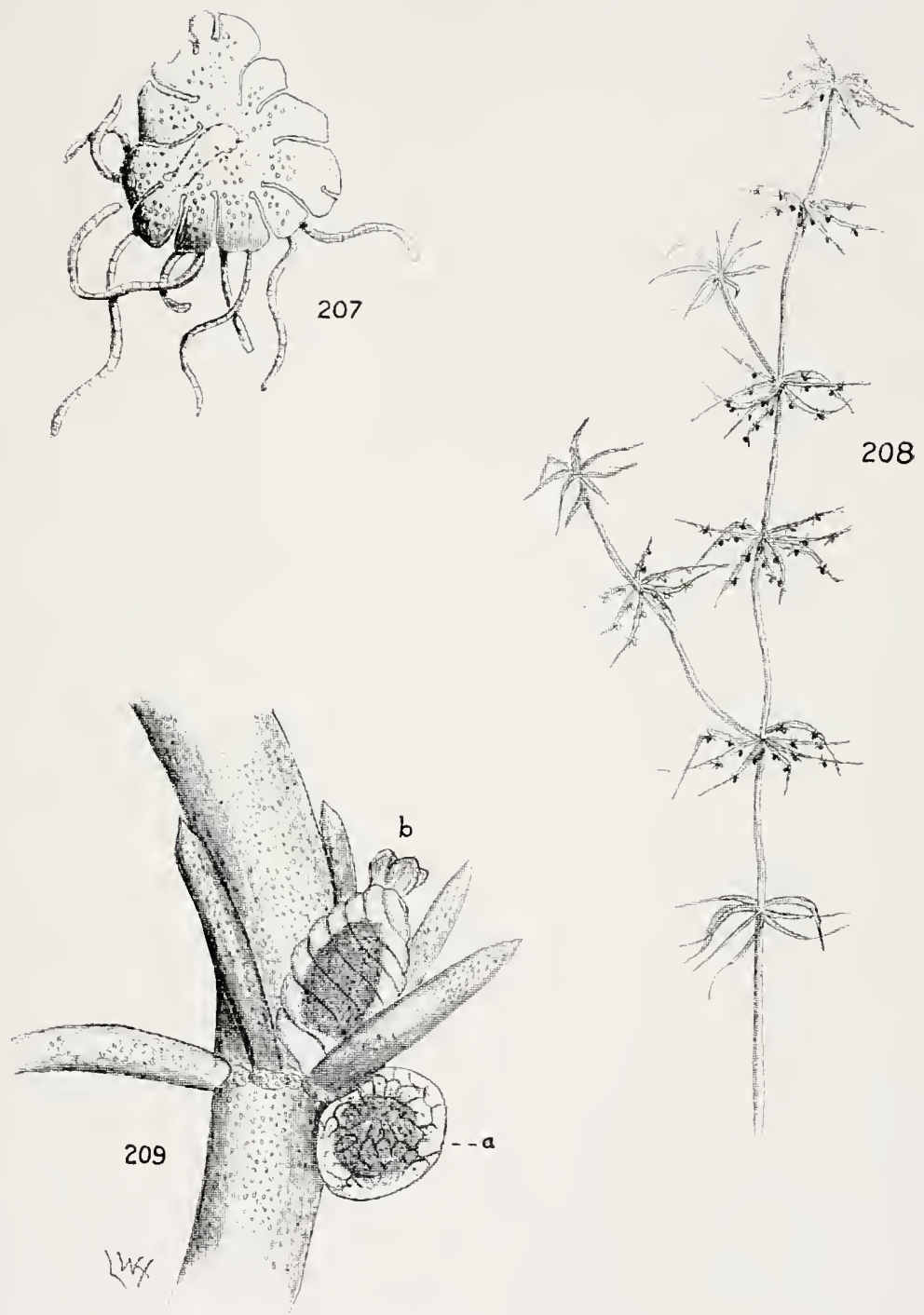


l'LATE NXIII; Figures 2 IO TO 216.

Fig. 2ı. Chrö̈coccus coharns (Breb.) Näg. page I4

Fig. $210 a . \quad$ ". $\quad$ (I000 diam-

eters)

Fig. 211. Nostoc minntissimus Kütz. . . “ 21

Fig. 21 1 . " “ $\quad$ " $\quad$ " Single

thread ( Iooo diameters)

Fig. 212. Tetraspora lubrica (Roth.) var.

lacunosa Chand. . . . . . . 30

Fig. 2Iza. Tetraspora lubrica var. lacunosa

Chand. ( IOOO diameters) . . . . .

Fig. 2I3. Sorastrum spinulosum Näg. (1000

diameters) . . . . . . . 37

Fig. 2I4. Glacotrichia pisum (Ag.) Thur. . . .

Fig. 215. Hydrodictyon reticulatum (L.) Lag. “. 38

a. Natural size

b. Young colony, slightly magnified

c. Full grown colony, highly magnified

Fig. $2 \mathrm{I}$ 6. Wicrospora Wittrockii (Wille) Lag. 


\section{PLATE $X X X I 1$.}

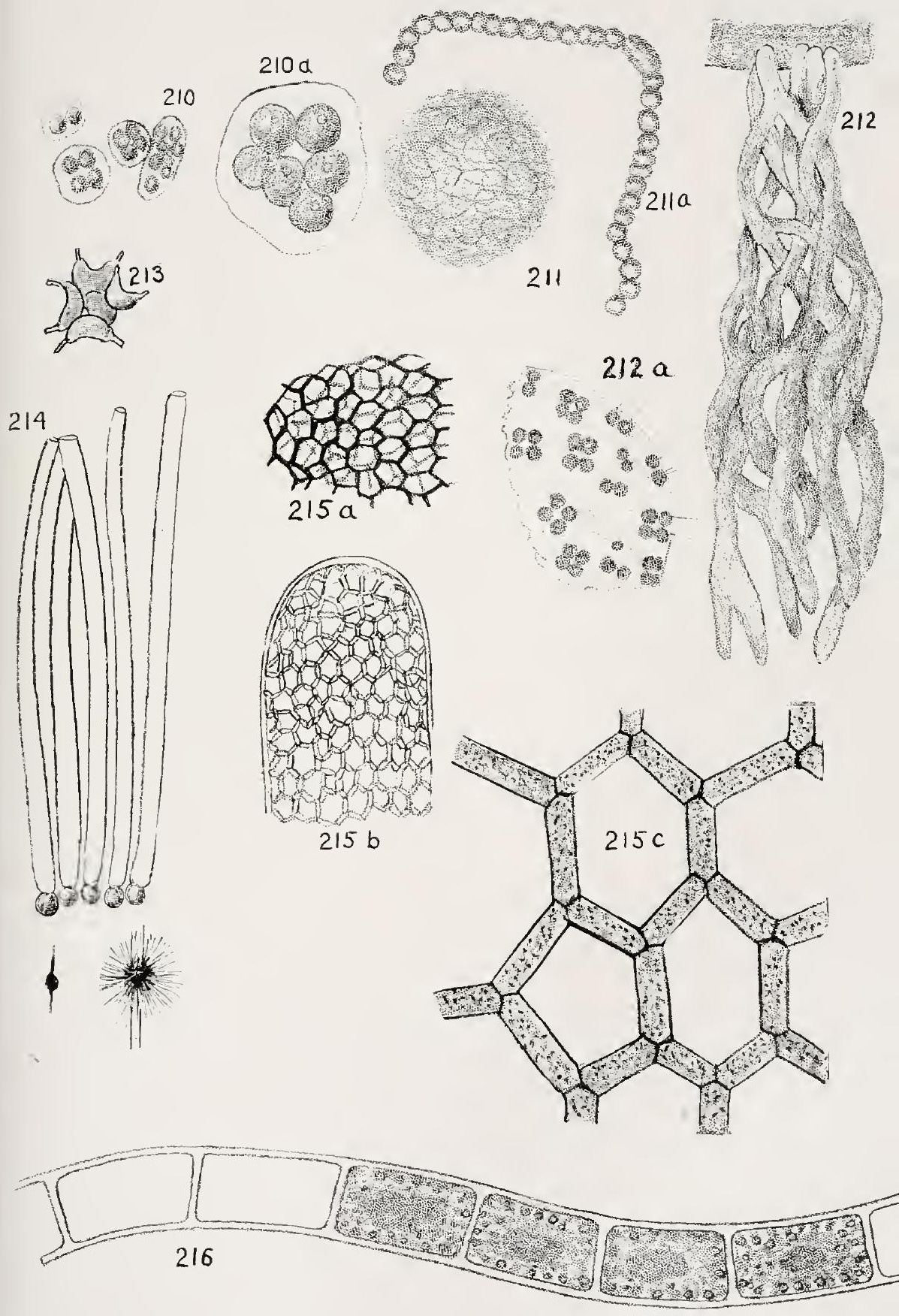


Plite XXXIII; Figures 2 I7 TU 220.

Fig. 217. Draparnaldia glomerata Ag. $\quad(250$ (liameters) . . . page 48

Fig. 2ıs. Penimu Naricula Breb. (I000 (liameters) . . . . . . . . . 60

Fig. 2I9. Mesotchinum micrococcum (Kütz.) Roy and Biss. ( Iooo diameters) * 57

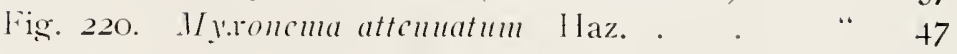


PLATE XXXIII.

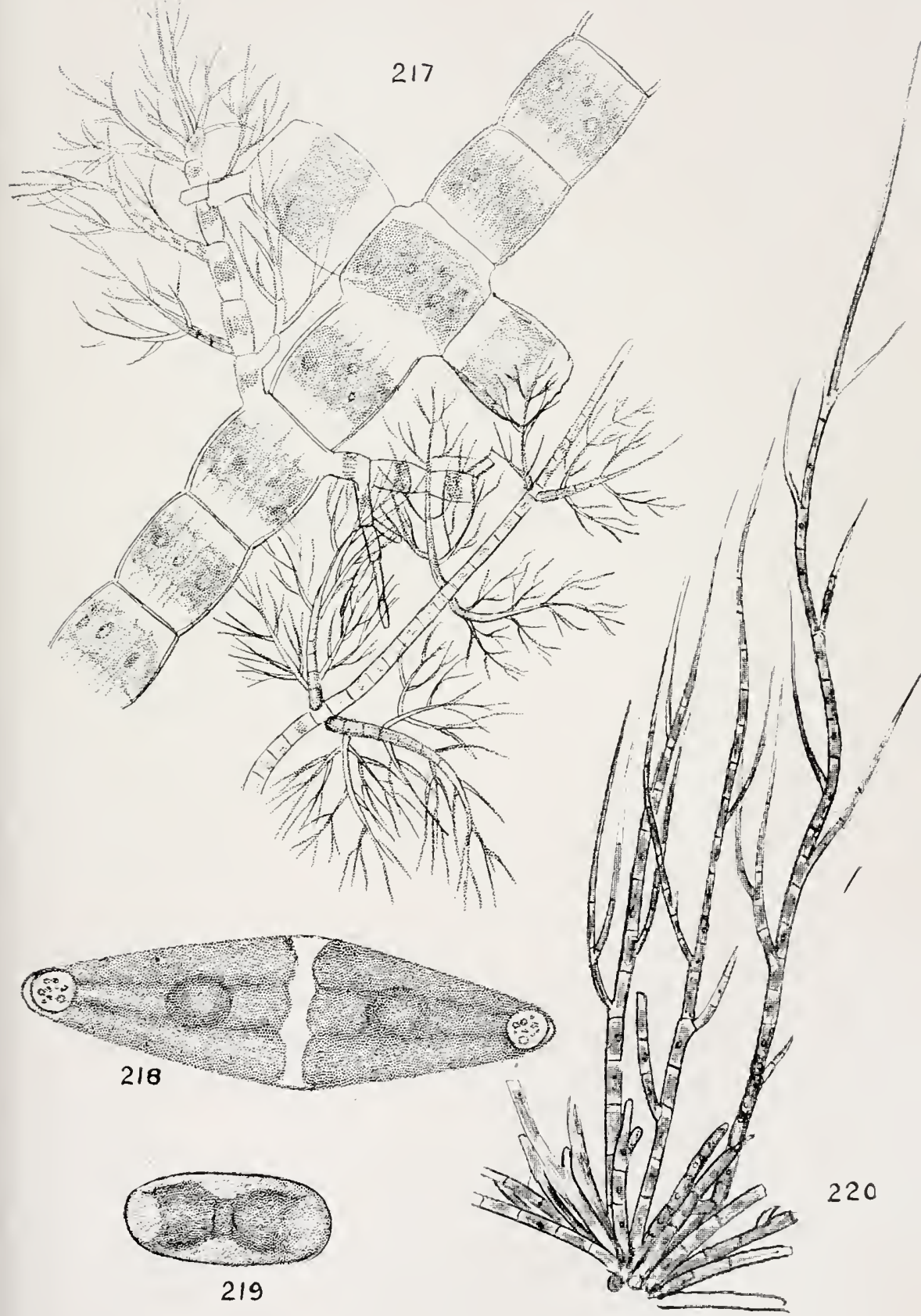


Plite IXXIV: Figures 22I, 222.

Fig. 22I. Chatophora incrassutu (Huds.) Haz. Upper figure, natural size; lower figure, highly magnified. . . page 47

Fig. 222. Chatophora pisiformis (Roth.) Ag. $a$, colony, natural size. $b$, a single filament 

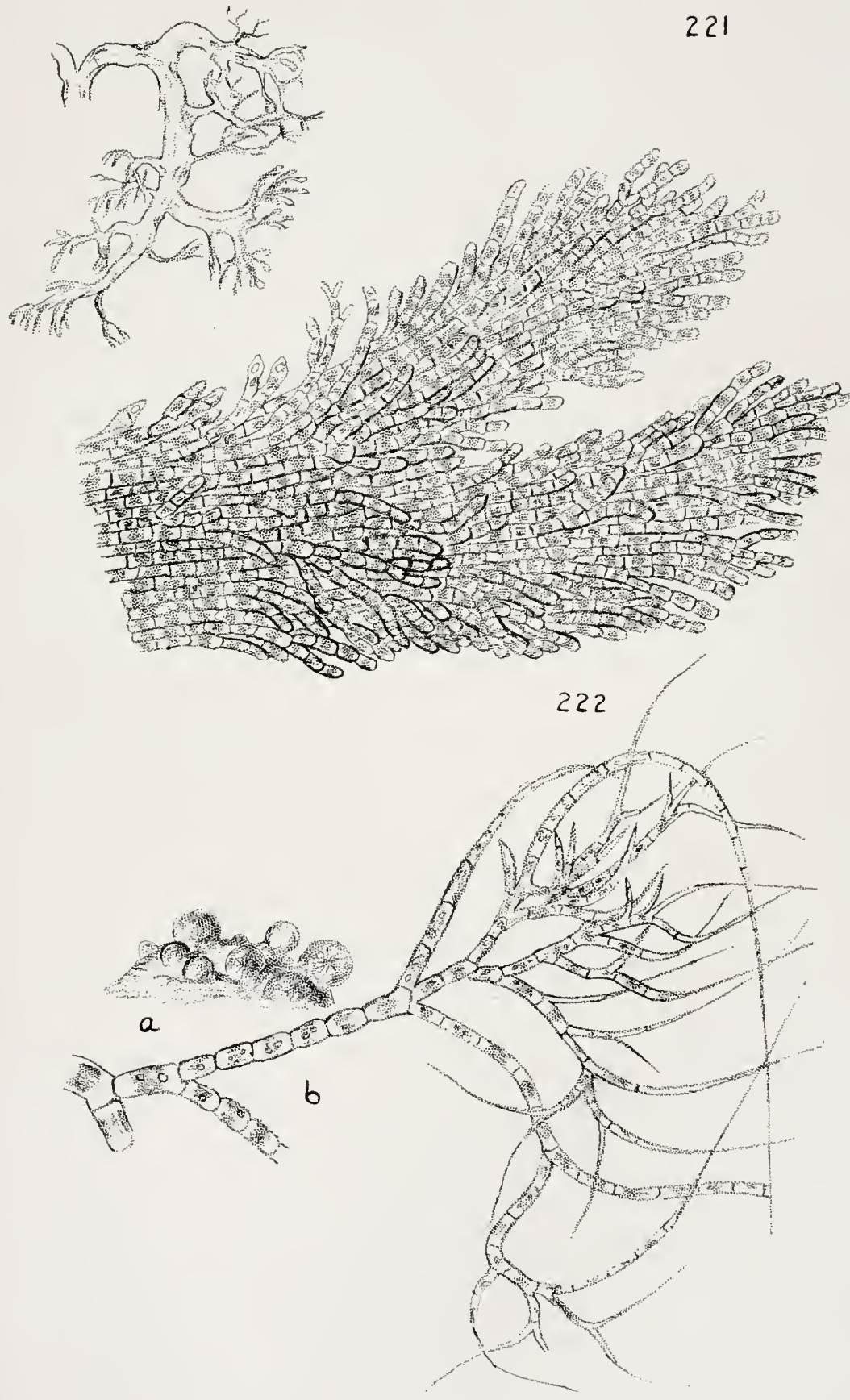
Plate NANi: Figures 223 to 228: Mlagxified 500 DiamETERs, Except Fig. 228.

Fig. 223. Docidium Baculum Breb. . . page 6r Fig. 224. Pleurotcnium crenulatum (Ehrb.)

Rab.

Fig. 225. Pleurotanium Archerii (Delp.)

Fig. 226. $\quad$ " Trabecula (Ehrb.) Näg. " "

Fig. 227. Euastrum sp. (?) . . . . . . " 63

Fig. 228. Edogonium cardiacum (Hass.)

Wittr. (?) . . . . . . . . 52 


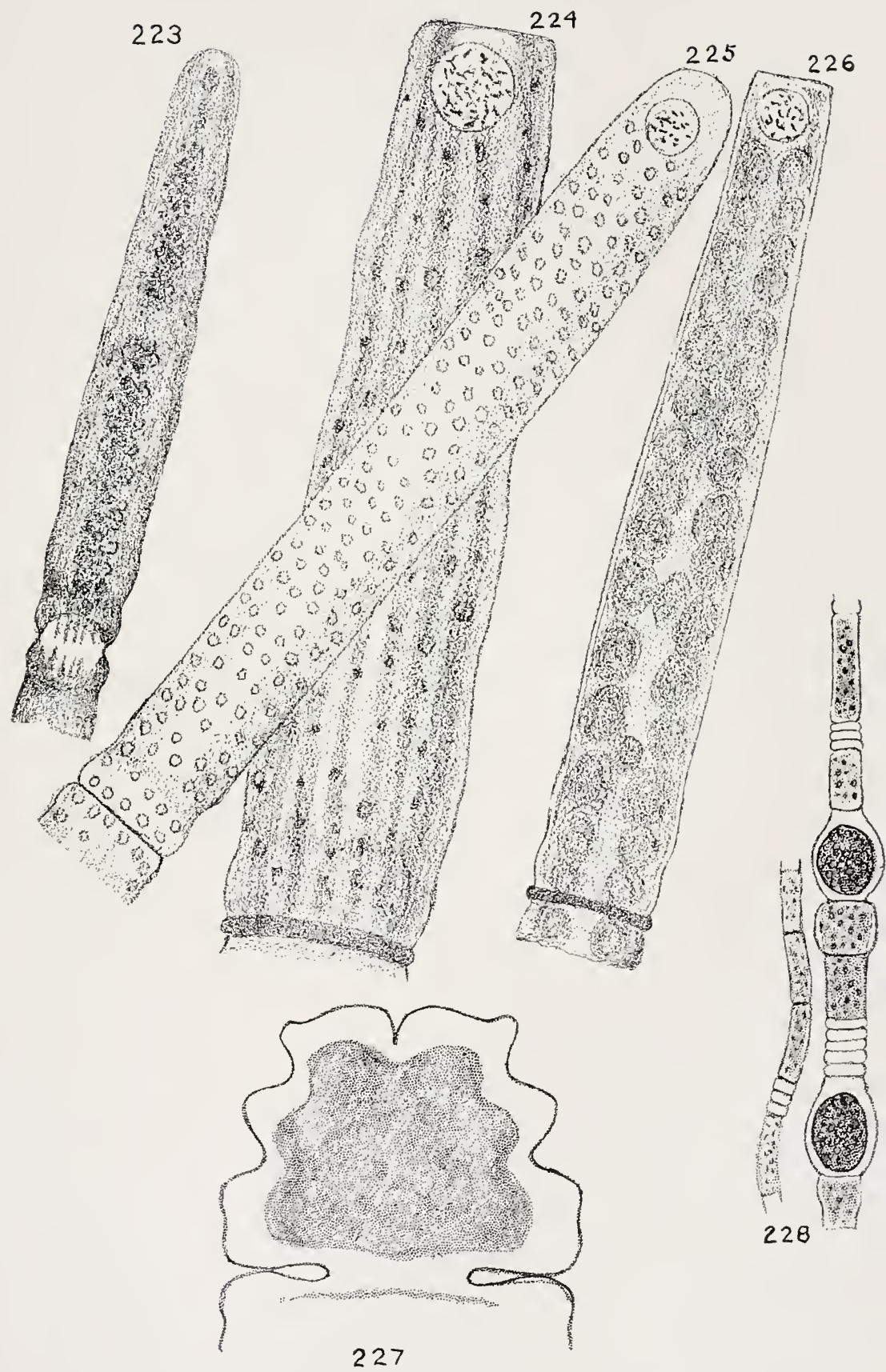


Plate XXXl1: Figures 229 to 237: MAgnifien Iooo DIMAETERS.

Fig. 229. Enastrum oblongatmm (Grev.) Ralfs page 62 Fig. 230. " ampullacemm Ralfs . . . .

Fig. 231. Stanrastrum cromulatmm (Delp.)

Näg. End view . .

liig. 231a. Stamrastrmu cromlatum (Delp.)

Sicle view

Fig. 232. Enastrmm elegans. Kütz. .

Fig. 233. Stanrastrmm dejectnm Breb. .

Fig. 233a. $230 \quad$ ". End view

Fig. 234. Enastrum Nordstedtiannm Wolle

Fig. 235. Stamastrmm margaritacenm Ehrb. .

Fig. $235 \%$.

Sicle view

Fig. 236. Stanrastrum dejectmm lireb. liig. $236 a$.

liig. 237 .

Fig. $237 a$. .. $\quad$ gracile Ralfs

Sicle view

$\begin{array}{ccc}. & \text {.. } & \text {.. Sirle view }\end{array}$




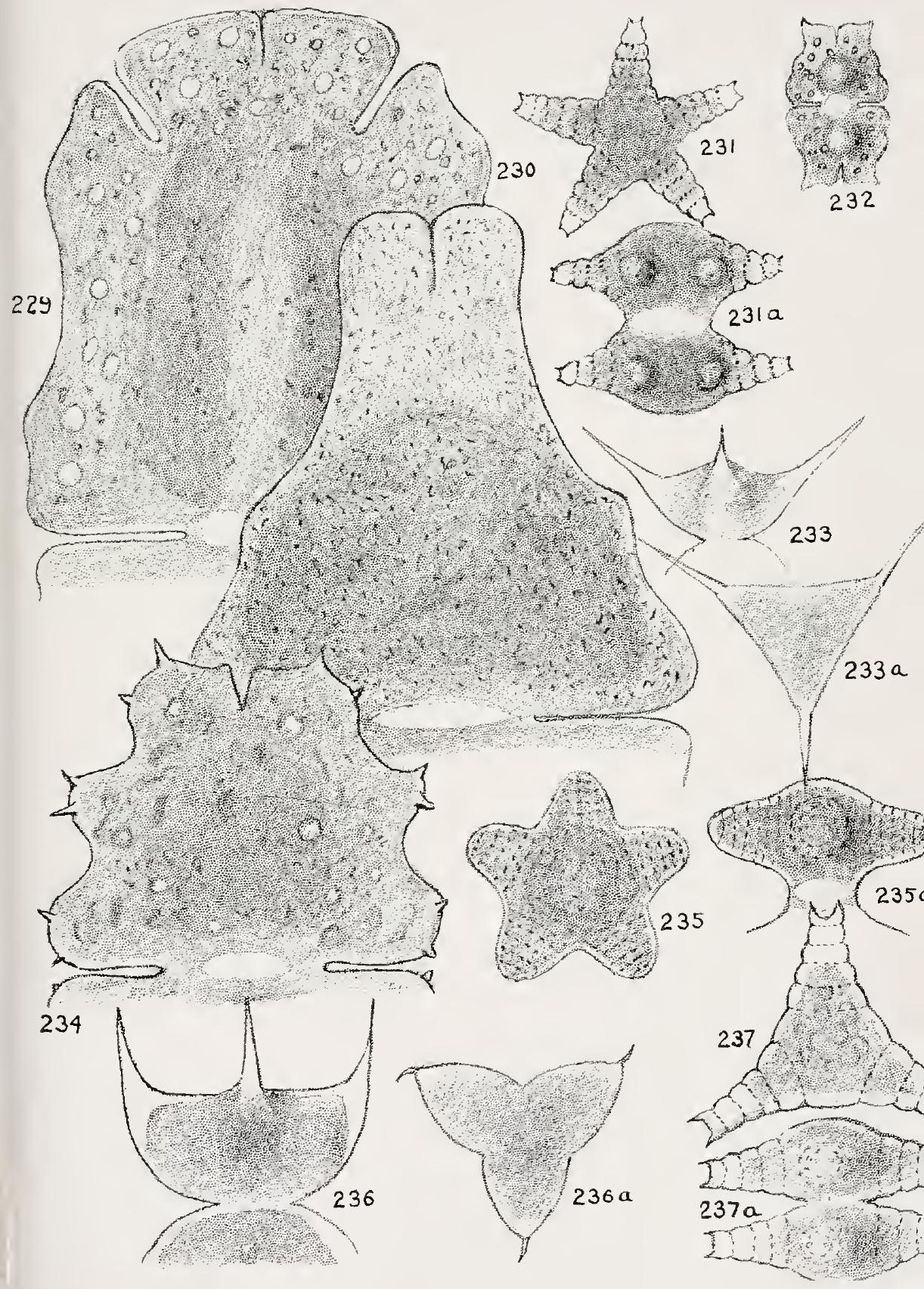


Plate XXXYil; Figures 238 to 244; Mignified 500 Diameters, except Figs. $243,244$.

Fig. 238. Micrastcrias rotata (Grev.) Ralfs page $6_{3}$ Fig. 239. ucata (Ag.) Ralfs.

Fig. 240. ". Alllericana (Ehrb.) Kütz. " ".

Fig. 2+1. " muricata Bail. . . ". "

Fig. $242 . \quad$ " truncata (Corda) Ralfs " "

Fig. 243. Colcochata scutata Preb. . . " "

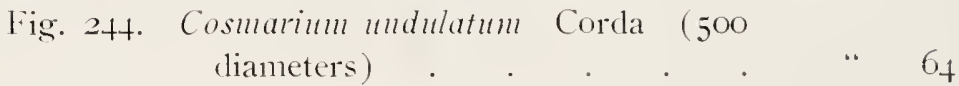


PLATE XXXVII.

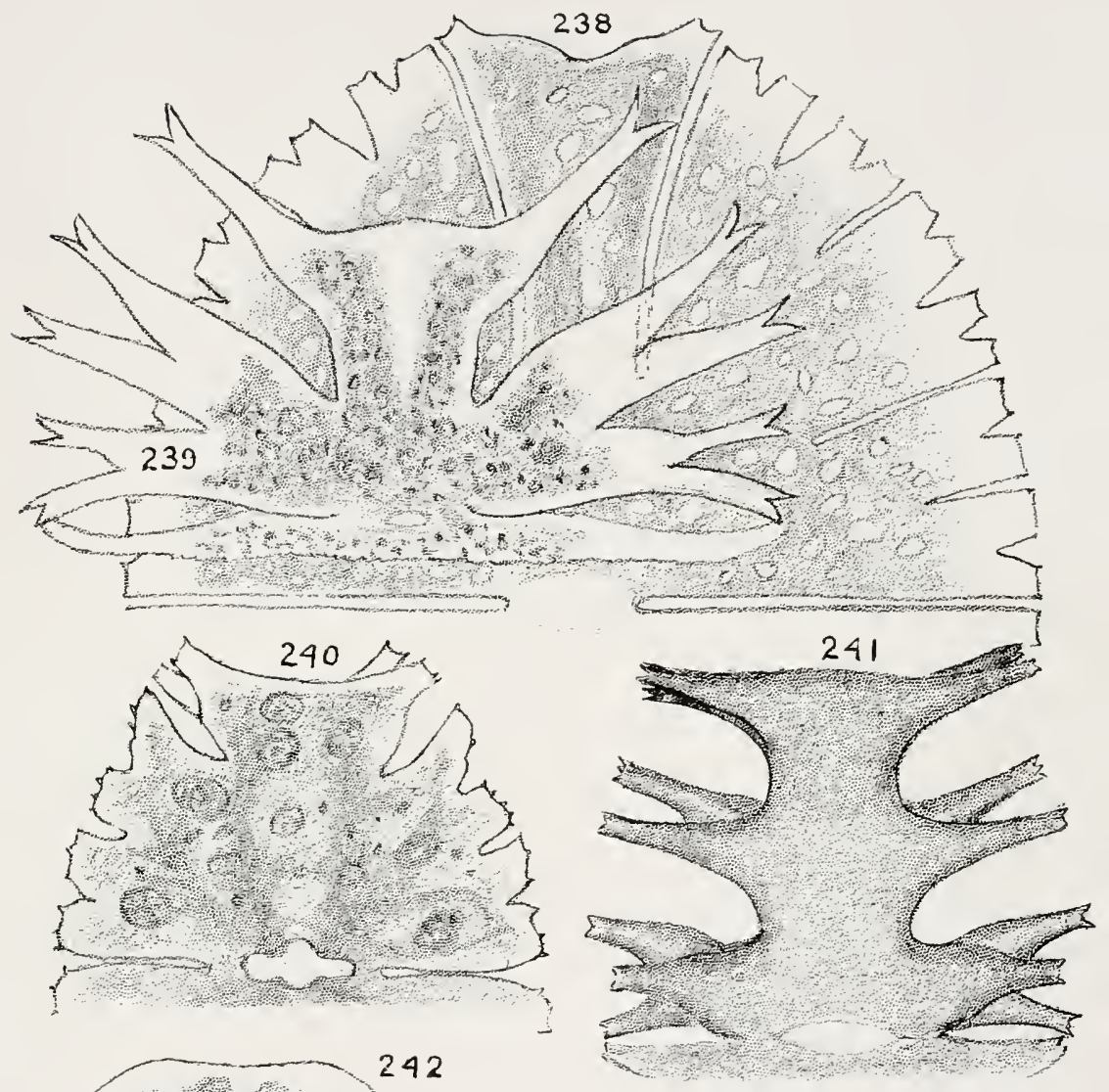

s.
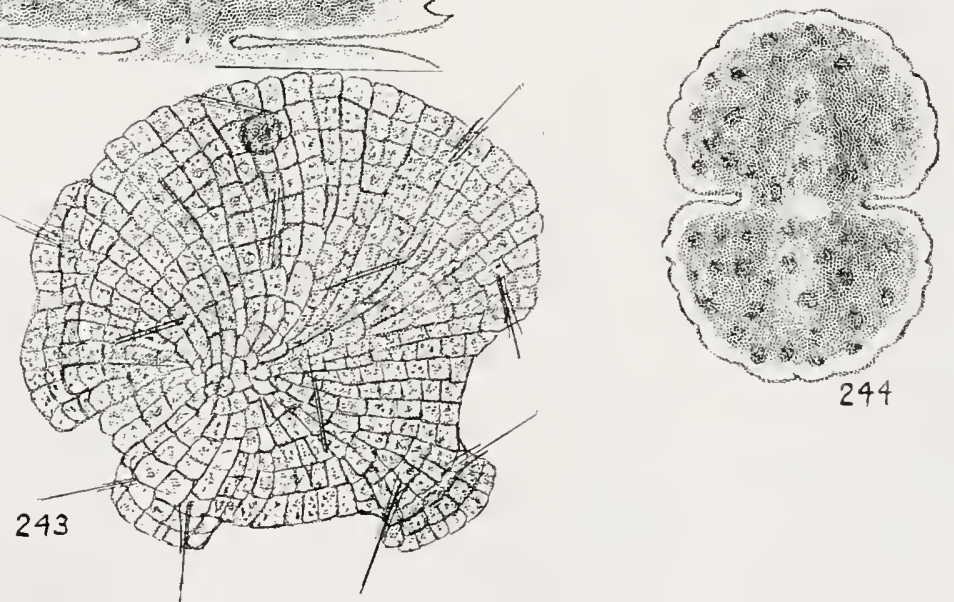
I'L.ITE XXXYIII: Figukes 245 TO 253 : MAGxified IOOO Dihineters.

Fig. 245. Cosmarim orale Ralfs . . . page $6_{4}$ Fig. $246 . \quad$.. plramidatm Breb. . .. “. Fig. 247. ". Meneghinii breb. . ". ". Fig. 248. *. octhodes Nord. Fig. 249. $\quad$. perforatum Lund. Fig. 250. ‥ Nägelianmm Pireb. Fig. 25I. $\quad . \quad$ intermedinm Delp. Fig. 252. ‥ Portiminm Arch. Fig. 25. * orbiculatum Ralfs 


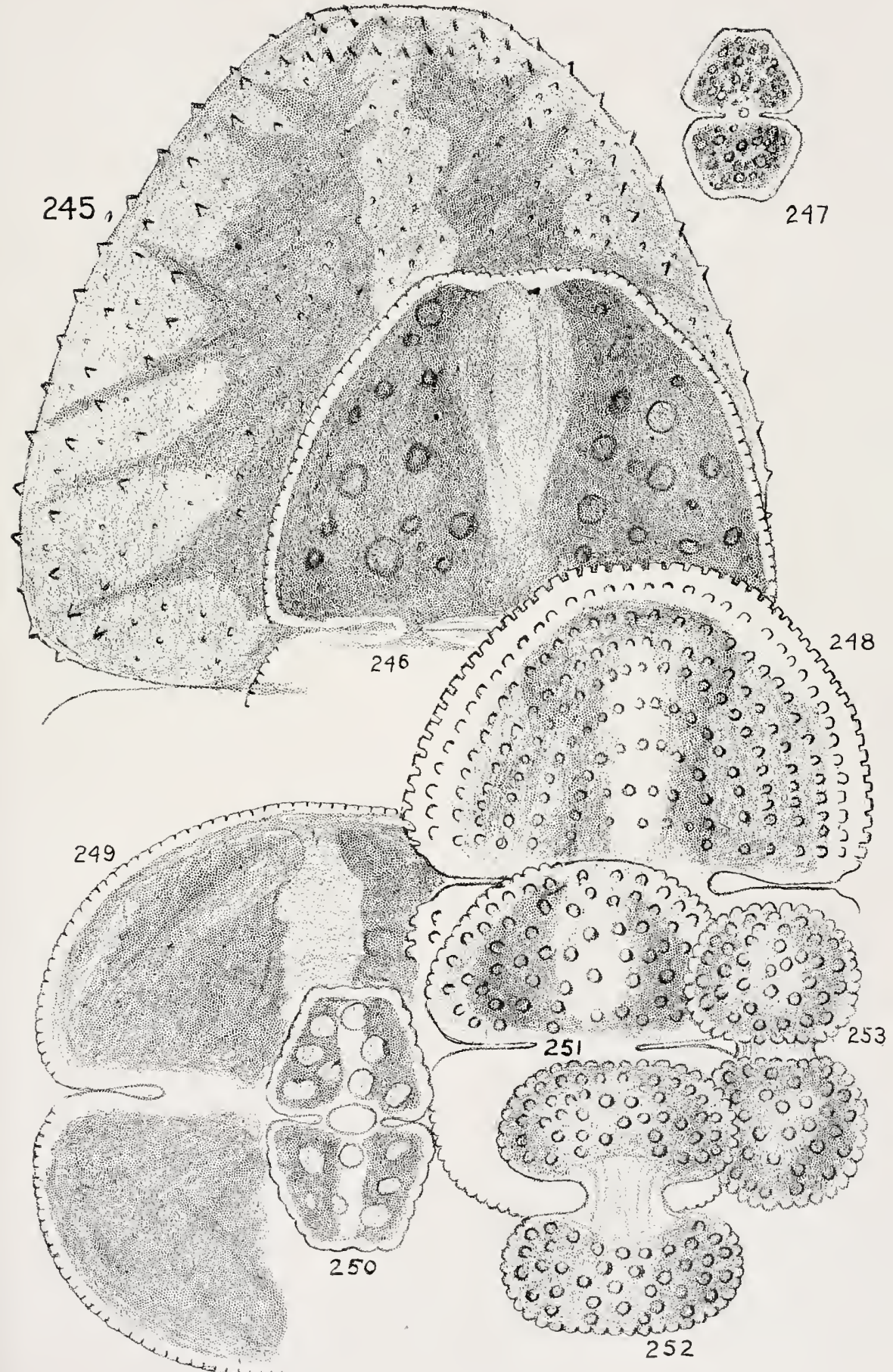


Plite XXNix: Figures 254 TO 260: Migifified IOOO DiAMETERS.

Fig. 254. Cosmarim tetrophthalmum (Kütz.) Breb. . . . . page 64 Fig. 255. Cosmarium galcritum Nord. . . " " Fig. 256. " Cucurbita Breb. . " " " Fig. 257. . " psendobroomei Wolle . " " Fig. $257 a$. End riew

Fig. 258. Cosmarim Broomei Thwaites. End view

Fig. 259. Arthrodesmus contergens (Ehrb.) Ralfs . . . . . . . . 63

Fig. 260. Arthrodesmus octocomis Ehrb. . “ “" 

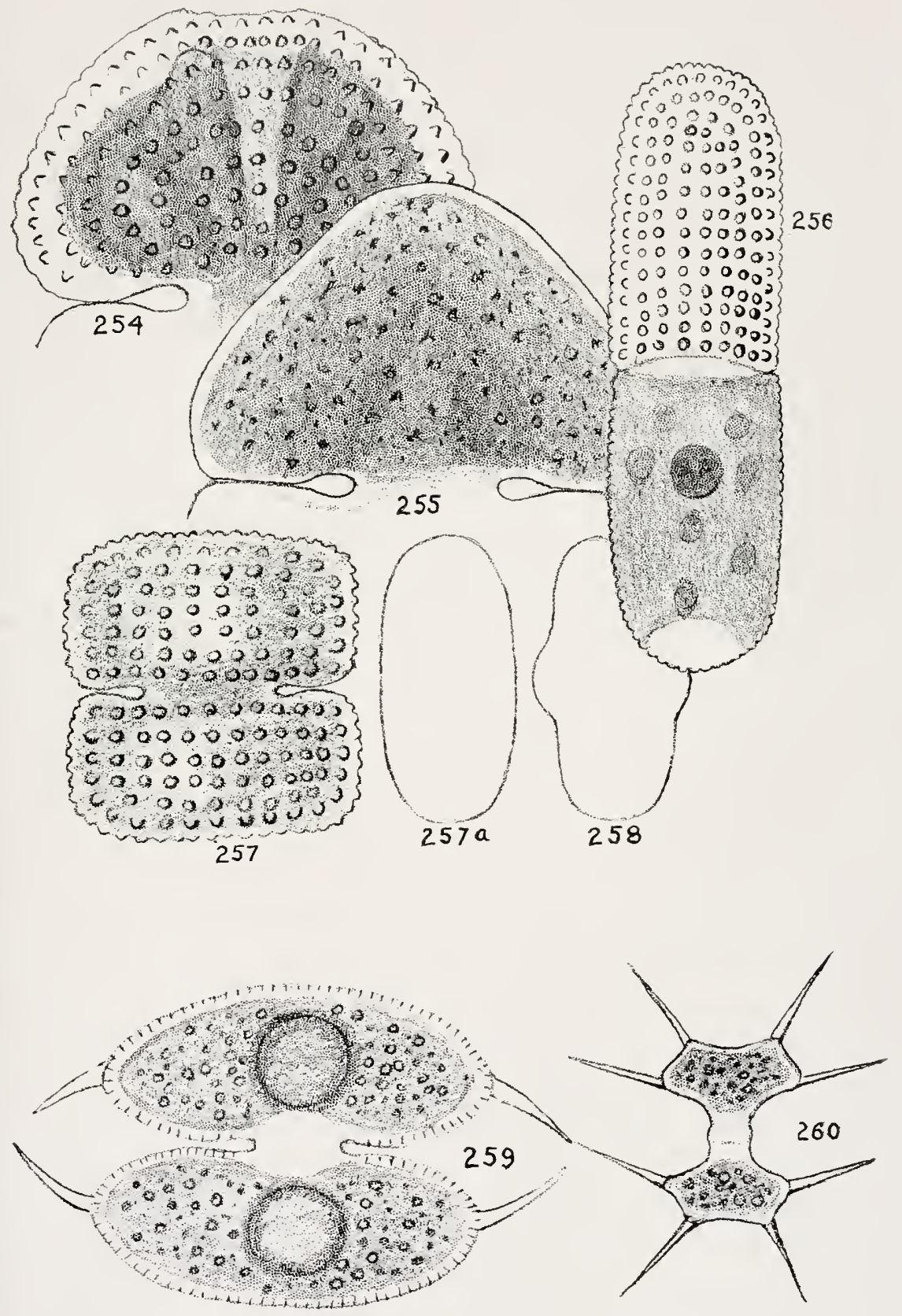
Plate NL: Figlres 26 i to 266 ; Miganified 1000 Dinaleters. Fig. 26I. Stanrastrum pygmamm lireb. Conjugating . . . . page 62

Fig. 262. Tanthidinm antilopanm (Breb.) Küitz. “. ". Fig. 263. Stumrastrum hirsntum (Ehrb.) Breb. Fig. 263 a.

$$
\text { Side view }
$$

Fig. 264. Stamrastmm leptocardimm Nord. . Fig. $26+0$.

Encl view

Fig. 265. Xanthidinm cristatmm (Breb.) Ralfs Fig. 266. ". fasciculatmm (Ehrb.) Ralfs var. subalpimm Wolle 


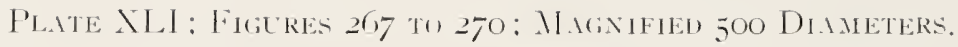
Fig. 267. Staurastrum coromulatum Wolle . page $\sigma_{2}$ Fig. $267 a$. End view

Fig. 268. Stanrastrum arctiscon Ehrb. . Fig. $268 a . \quad$ " $\quad$ " $\quad$ " Encl

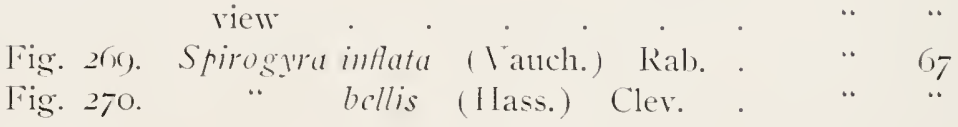



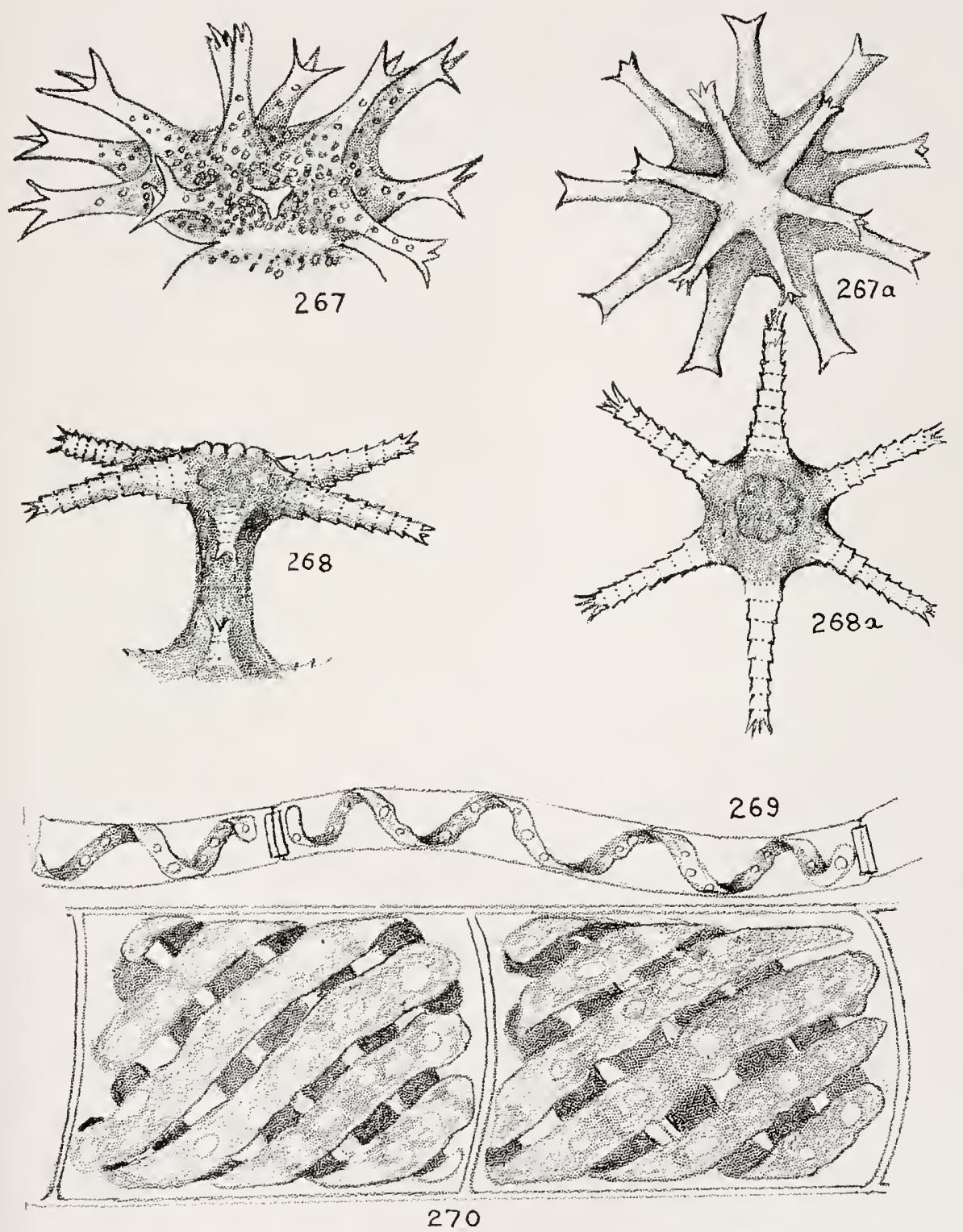


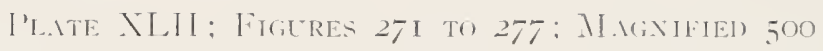
DI.IMETERS.

Fig. 2-т. Spharowosma pulcrmm liailey. . page 65 Fig. 272. $\quad$ ". serrutm (Bailey) Wall.

(, Side view; $b$, end view: $c$, view from above

Fig. 273. Hyalotheca dissiliens (Sin.) Breb.

Fig. 274. Cladophore slomerata (L.) Kïtz.

Fig. 275. Desmidim Sa'drtail Ag. a, Sirle view: $b$, end riew: $c$, side riew less magnified . . . . .

lig. 2-6. Desmidimm cylindricum (ires. Sicle view

Fig. 2jor. Desindimn cylindricum (irev. End viell

Fig. 277. Spharososma spinosmm (1)elp.) Wrolle 

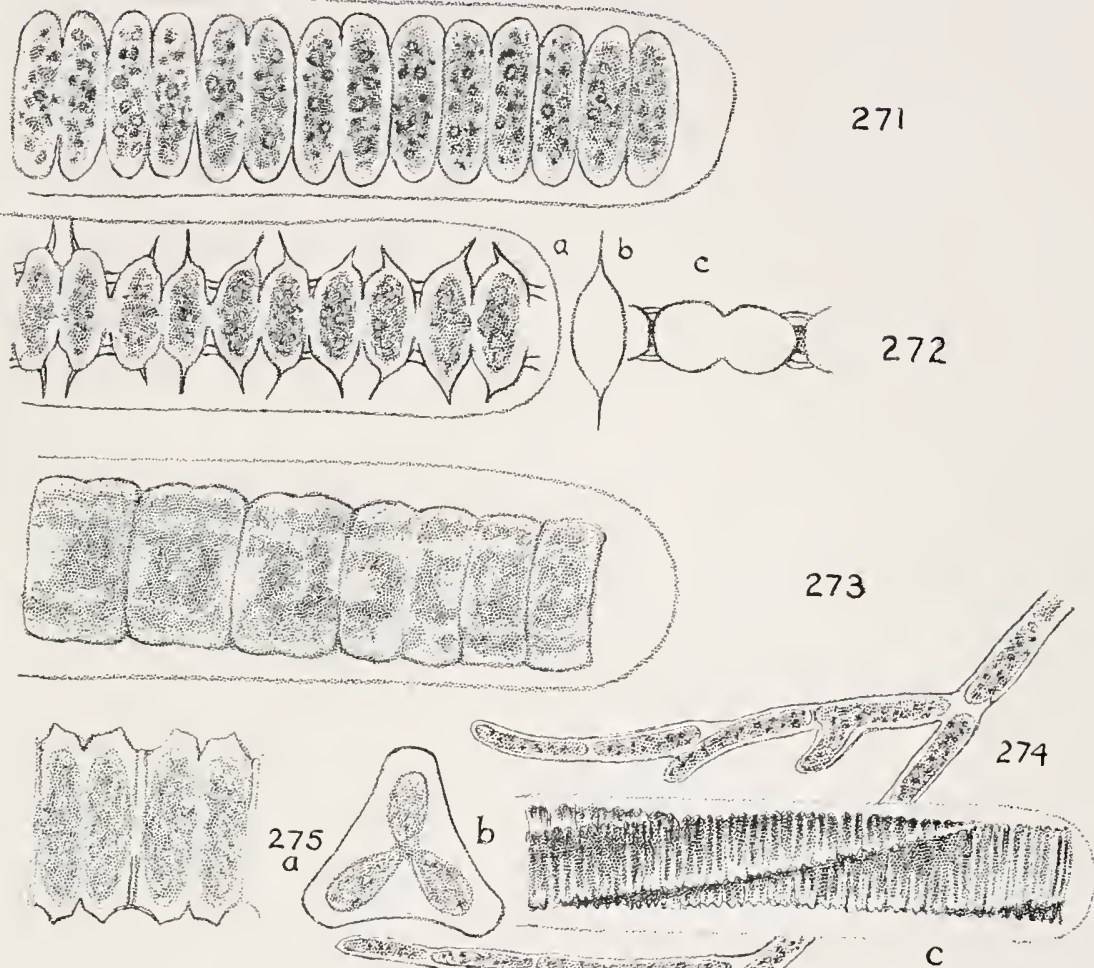

C

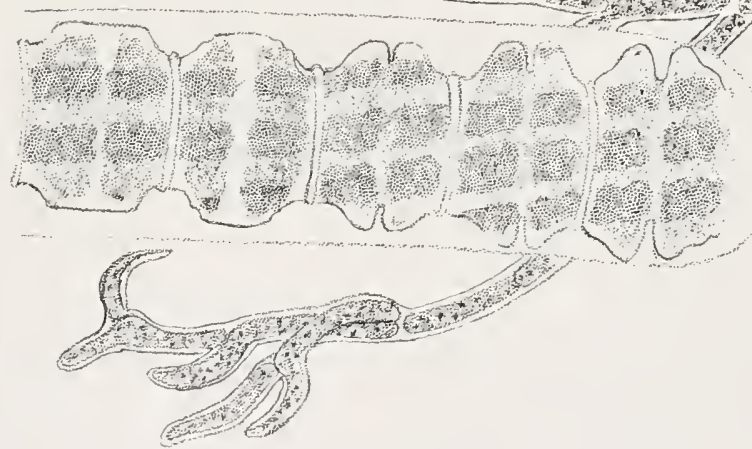

273
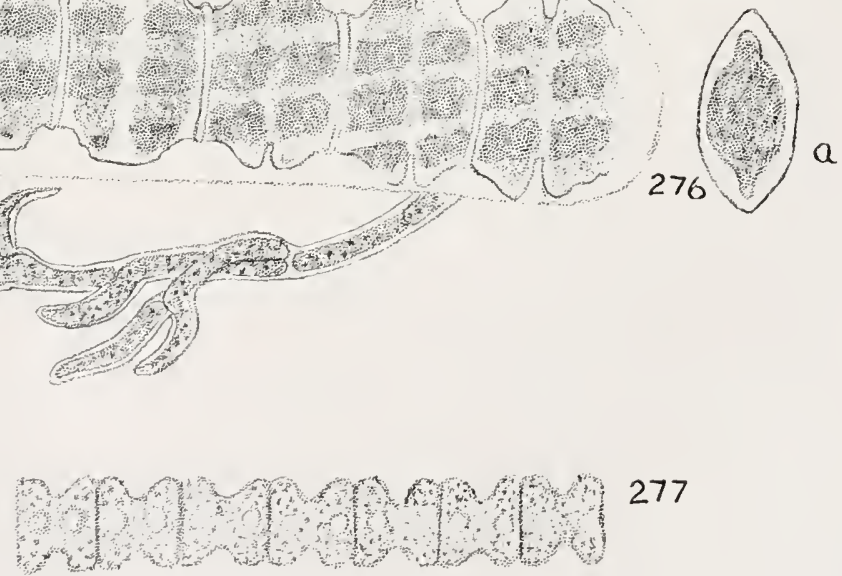
Plite Xlili ; Figures 278 TO 280.

Fig. 278. Batrachospermum i'agum Ag. . page 7.3

Fig. 279. Zygnema pectinatum (Vauch.) Ag. ". 67 Fig. 280. Mougeotiu sp.(?). Conjugating . . . 68 
PLATE XLIII.

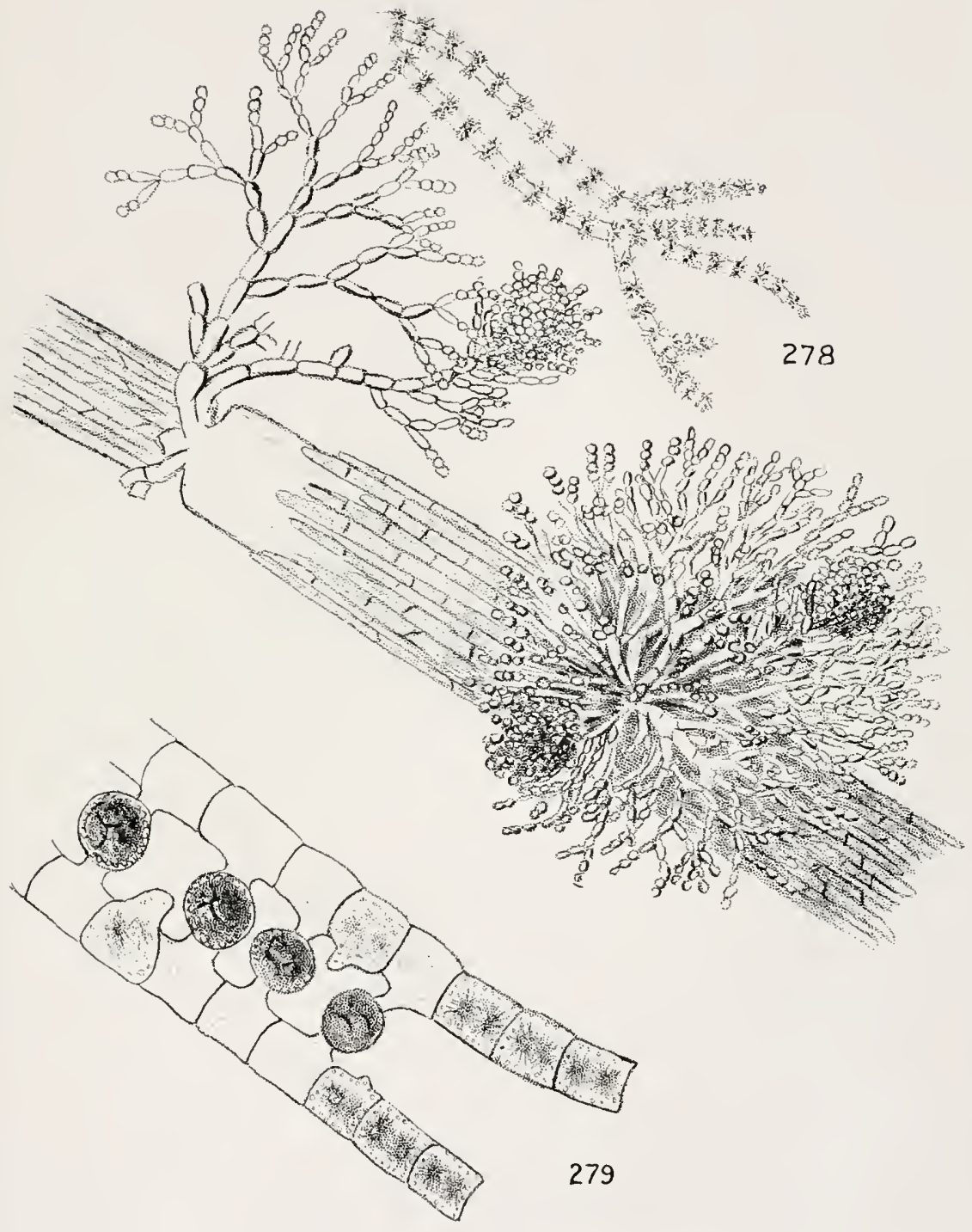




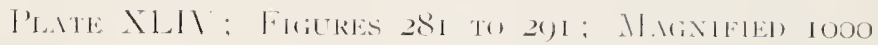
I)I.METERS.

Fig. 28s. Vetrimm intermptum (Brels.) Luitkenll . . . . page 58

lig. 282. Netrimm Digitns (Ehro.) Itz. and Roth.

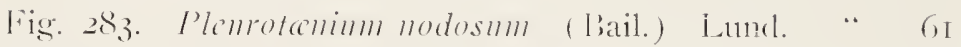
lig. 28t. Mgromema numm (1)illw.) Haz. " Fig. 285. Endorina elegans Ehrb. . . . ". + +

Fing. 285. Pandorima mormm (Miill.) bory. " +2

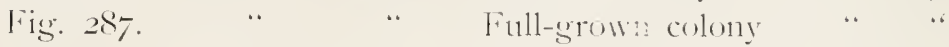

Fig. 288. Spondylomormm anatermarim Ehrl). "

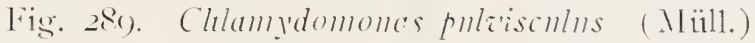

Ehrb. . . . . . . . . . 40

ling. 200. Carteria (Chlambdomonas) multifilis

(Fresent.) (?) . . . . . . . . .

lin. 201. Spirnlina teminssima Kït. . . . . . 


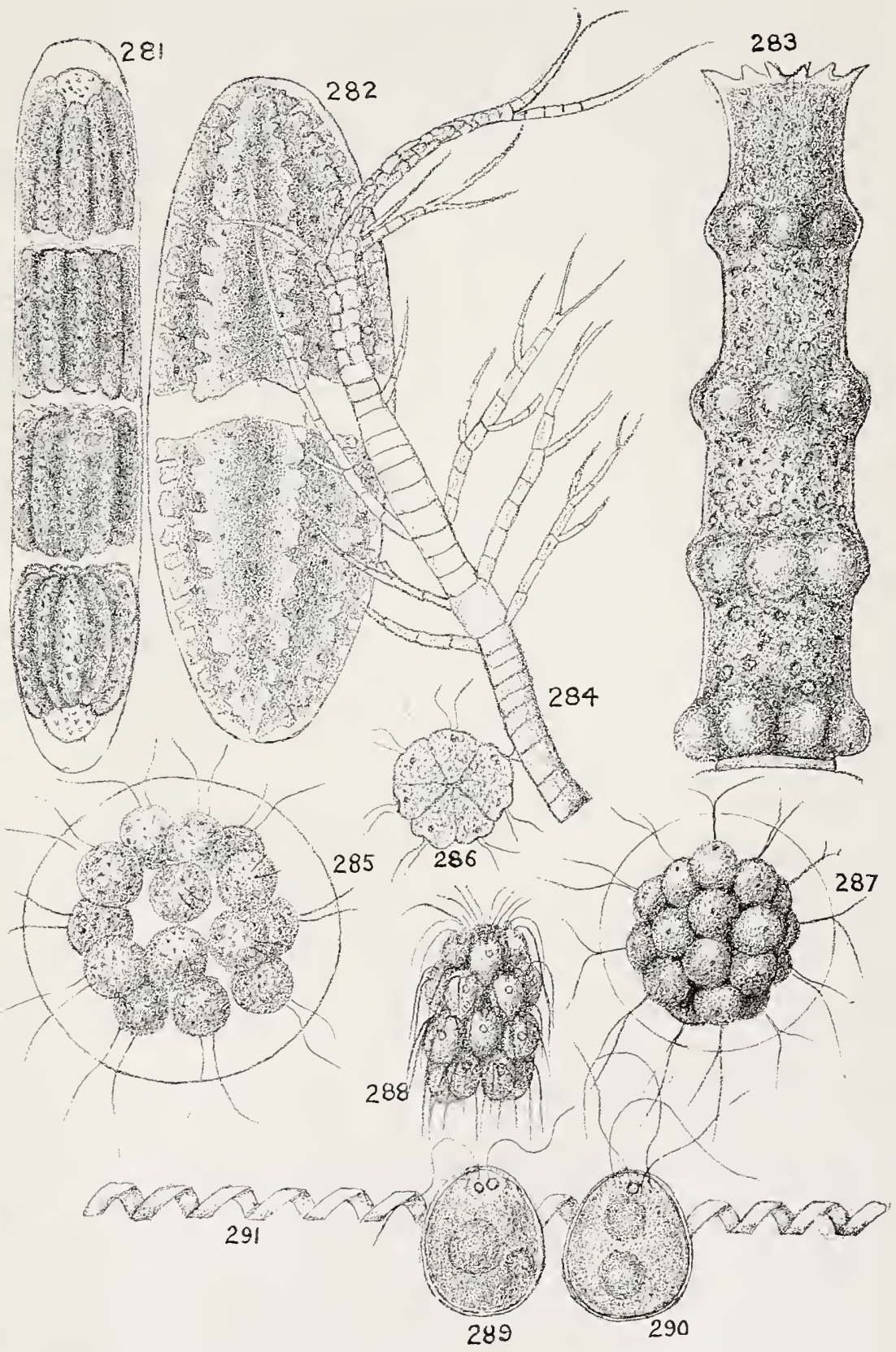










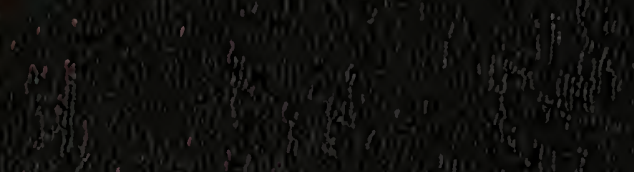

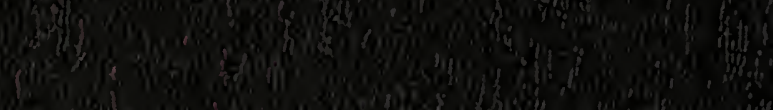

年4 -

4. 5.

(8)

(1)

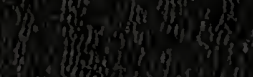

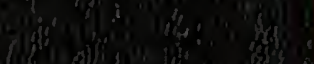

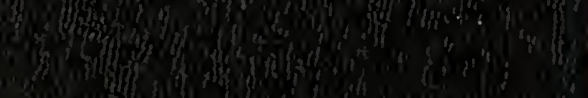

